University of Louisville

ThinkIR: The University of Louisville's Institutional Repository

Electronic Theses and Dissertations

$5-2020$

\title{
Susceptibility assessment of bank and floodplain erosion in stream restoration using a two-dimensional hydrodynamic.
}

Fereshteh Noorbakhsh

University of Louisville

Follow this and additional works at: https://ir.library.louisville.edu/etd

Part of the Hydraulic Engineering Commons

\section{Recommended Citation}

Noorbakhsh, Fereshteh, "Susceptibility assessment of bank and floodplain erosion in stream restoration using a two-dimensional hydrodynamic." (2020). Electronic Theses and Dissertations. Paper 3380.

https://doi.org/10.18297/etd/3380

This Doctoral Dissertation is brought to you for free and open access by ThinkIR: The University of Louisville's Institutional Repository. It has been accepted for inclusion in Electronic Theses and Dissertations by an authorized administrator of ThinkIR: The University of Louisville's Institutional Repository. This title appears here courtesy of the author, who has retained all other copyrights. For more information, please contact thinkir@louisville.edu. 
SUSEPTIBILITY ASSESSMENT OF BANK AND FLOODPLAIN EROSION IN

STREAM RESTORATION USING A TWO-DIMENSIONAL HYDRODYNAMIC

MODEL

By

Fereshteh Noorbakhsh

B.S., University of Tabriz, Iran, 2009

M.S., Power and Water University of Technology, Iran, 2013

A Dissertation

Submitted to the faculty of the

J. B. Speed School of Engineering of the University of Louisville In Partial Fulfillment of the Requirements for the Degree of

\author{
Doctor of Philosophy \\ in Civil Engineering \\ Department of Civil Engineering \\ University of Louisville \\ Louisville, Kentucky
}

May 2020 
Copyright 2020 by Fereshteh Noorbakhsh

All rights reserved 

SUSEPTIBILITY ASSESSMENT OF BANK AND FLOODPLAIN EROSION IN STREAM RESTORATION USING A TWO-DIMENSIONAL HYDRODYNAMIC MODEL

By

Fereshteh Noorbakhsh

A Dissertation Approved on

March 25, 2020

By the following Dissertation Committee:

Dissertation Director: Dr. Arthur Parola

Dr. Thomas Rockaway

Dr. Erin Gerber

Dr. Nageshwar Bhaskar 


\section{ACKNOWLEDGMENTS}

I would like to extend my deepest gratitude to my advisor, Dr. Arthur Parola, who provided me with encouragement and patience throughout the duration of my research. It has been great honor to have known him and work for him. Dr. Parola has always have practical suggestions and profound belief in my work which provided me an increasing motivation for doing my research and enjoy the difficulties of performing my dissertation.

I also would like to express my appreciation to my committee Dr. Thomas Rockaway, Dr. Erin Gerber, and Dr. Nageshwar Bhaskar for the technical conversations and constructive advice about my research as well as the helpful ideas for conducting different simulations.

I gratefully acknowledge the help and contributions that I received from the staff at Stream Institute at University of Louisville. I also wish to thank to all my friends and colleagues for their valuable experience and friendship.

Nobody has been more important to me in the pursuit of this dissertation than the members of my family. I deeply thank my parents for their endless patience, timely encouragement, and unconditional support. My sisters who have been generous with their love and encouragement despite the long distance between us.

Most importantly, I wish to thank my loving husband and supportive best-friend, Hadi, who helped me get through these years in the most positive way and unending inspiration and encouragement. 


\begin{abstract}
SUSEPTIBILITY ASSESSMENT OF BANK AND FLOODPLAIN EROSION IN STREAM RESTORATION USING A TWO-DIMENSIONAL HYDRODYNAMIC MODEL
\end{abstract}

Fereshteh Noorbakhsh

March 25, 2020

In the design of stream restorations, boundary shear stress (shear stress) and velocity during high flow events are the key parameters in the assessment of the risk of morphological failure associated with channel bank and bed erosion and sediment transport. The use of two-dimensional hydrodynamic models (2D Models) is becoming more common to estimate critical shear stress and velocity for stream restoration projects. These models can give detailed distribution of shear stress and velocity over floodplain surfaces and channel. Obtaining reliable and correct estimates of stress and velocity require an accurate digital terrain model, estimates of input flows at the upstream, approximation of water surface elevation at the downstream, and surface roughness coefficients. Obstacles to the use of these models include the cost associated with extensively detailed terrain surveys, distributed information about the roughness coefficients, and the determination of appropriate flow conditions that must be modeled to identify erosion susceptible components. In the present research, the reliability of the use of $2 \mathrm{D}$ models for predicting regions of streambanks and floodplain that are susceptible to erosion is assessed. For this 
purpose, two-dimensional hydrodynamic modeling software (TUFLOW) is employed to evaluate the accuracy of the model for assessing the risk of having erosion by comparing with field observation. Also, the results of this study have been compared with the existing recommendations for the risk of having erosion.

Topography and hydraulic data obtained from monitoring efforts of the restored channel and floodplain of Slabcamp Creek located in Rowan County, Kentucky was used to develop and calibrate the 2D Model. Also, the topographic data from the restored floodplain and channel of Brushy Creek located in Greenup County, Kentucky was used for doing the simulation as the second study site. Areas of bank and floodplain erosion were developed approximately from aerial surveys. The relations between the model hydraulic parameters and areas of observed erosion were developed based on model results and the aerial surveys. In both the Slabcamp and Brushy analysis for the bank and floodplain areas, shear stress over 4 psf and velocity over 6 fps showed high percentage area of erosion. 


\section{TABLE OF CONTENTS}

ACKNOWLEDGMENTS ........................................................................... iii

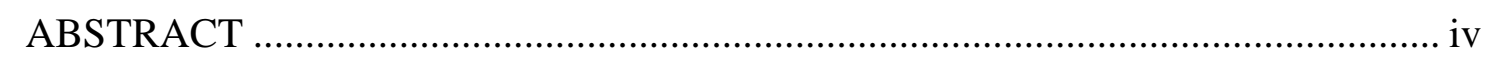

LIST OF TABLES ................................................................................... vii

LIST OF FIGURES ................................................................................... xi

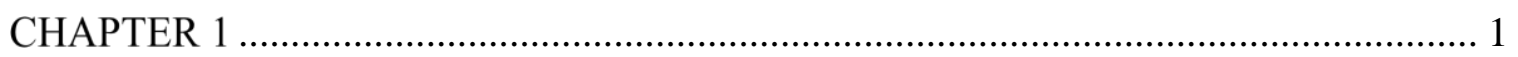

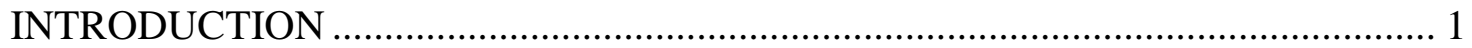

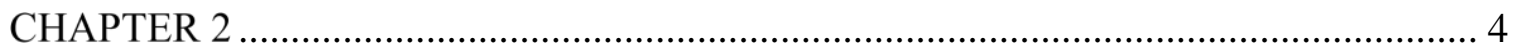

LITERATURE REVIEW ............................................................................ 4

2.1 Stream Restoration Overview ................................................................ 7

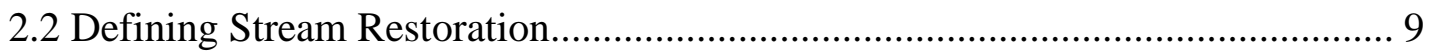

2.3 Stream Restoration Design and Evaluation Challenges................................. 11

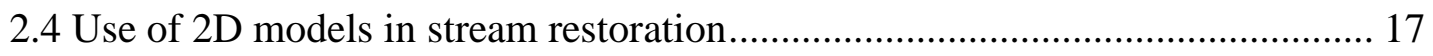

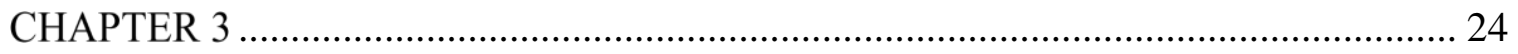

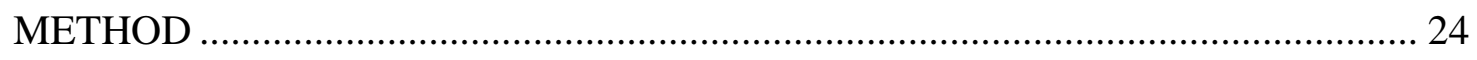

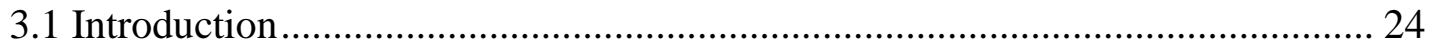

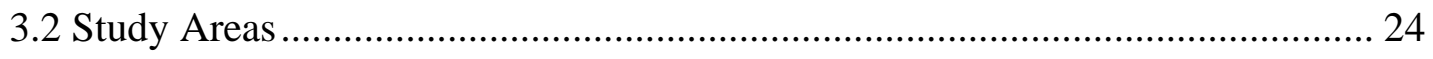

3.3 2D Models and Prediction of Bed Shear Stress and Velocity Magnitude .......... 29 


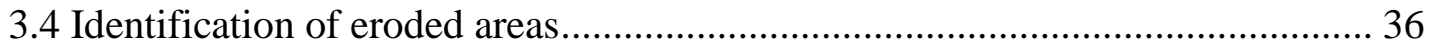

3.5 Bed Shear Stress and Velocity vs Erosion Histograms ...................................... 38

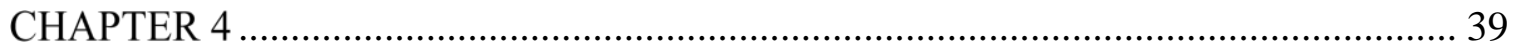

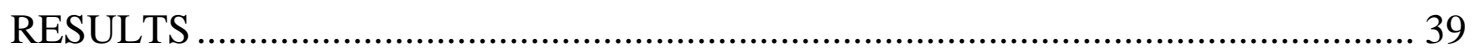

4.1 Slabcamp Creek Model Calibration................................................................ 39

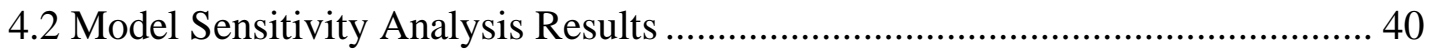

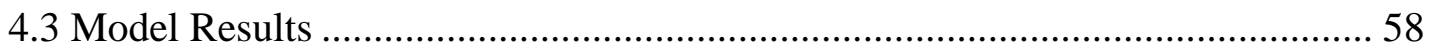

4.4 Shear Stress, Velocity Magnitude and Occurrence of Erosion............................ 85

4.5 Shear Stress and Velocity Magnitude and Occurrence of Bank and Floodplain

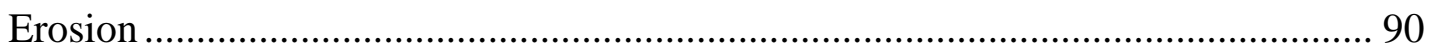

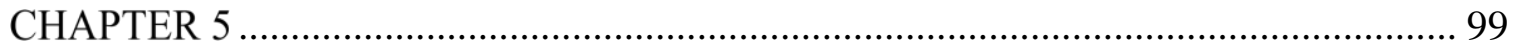

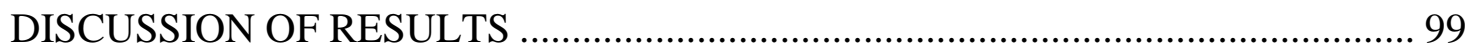

5.1 Model Sensitivity, Uncertainty and Error .......................................................... 99

5.2 Erosion Susceptibility of Floodplain \& Bank Surfaces .................................... 101

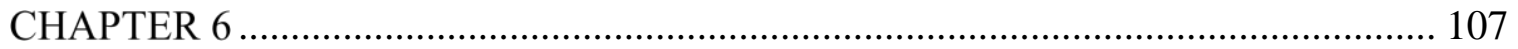

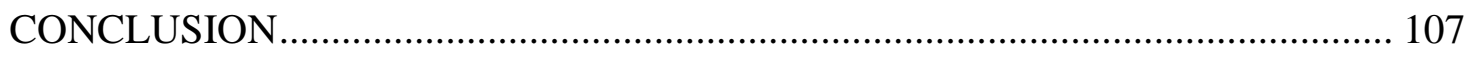

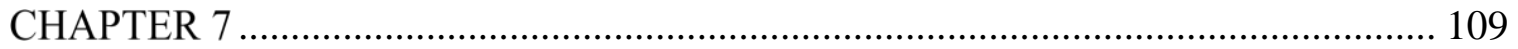

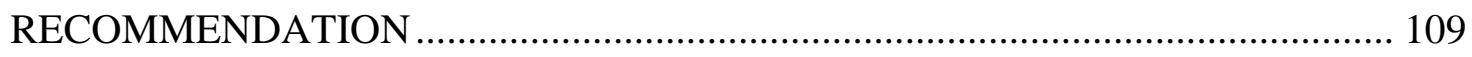

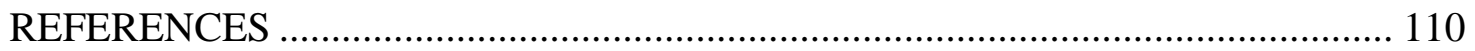

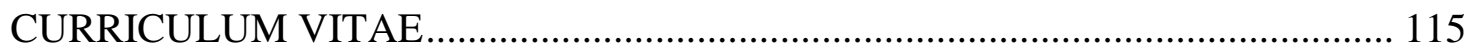




\section{LIST OF TABLES}

Table 1. StramStat Watershed Characteristics ............................................................. 32

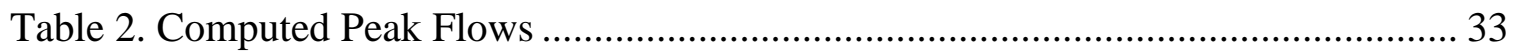

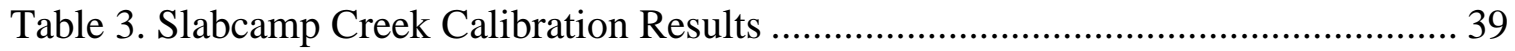

Table 4. Comparison of the average shear stress for different Inflow - Slabcamp Creek 48

Table 5. Comparison of the maximum shear stress for different Inflow - Slabcamp Creek

Table 6. Comparison of the average velocity for different Inflow - Slabcamp Creek ..... 48

Table 7. Comparison of the maximum velocity for different Inflow - Slabcamp Creek . 48

Table 8. Comparison of the average shear stress for different roughness - Slabcamp

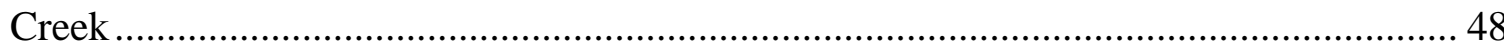

Table 9. Comparison of the maximum shear stress for different roughness - Slabcamp

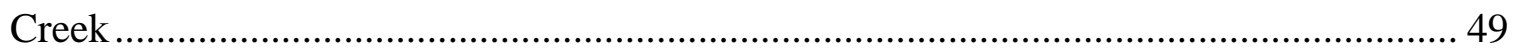

Table 10. Comparison of the average velocity for different roughness - Slabcamp Creek

Table 11. Comparison of the maximum velocity for different roughness - Slabcamp

Creek

Table 12. Comparison of the average shear stress for different Inflow - Brushy Creek.. 57

Table 13. Comparison of the maximum shear stress for different Inflow - Brushy Creek

Table 14. Comparison of the average velocity for different Inflow - Brushy Creek ....... 57 
Table 15. Comparison of the maximum velocity for different Inflow - Brushy Creek ... 57

Table 16. Comparison of the average shear stress for different Roughness - Brushy Creek

Table 17. Comparison of the maximum shear stress for different Roughness - Brushy

Creek 58

Table 18. Comparison of the average velocity for different Roughness - Brushy Creek 58

Table 19. Comparison of the maximum velocity for different Roughness - Brushy Creek 58

Table 20. Numerical results of velocity distribution for floodplain - Slabcamp Creek ... 64

Table 21. Descriptive statistics of velocity for floodplain - Slabcamp Creek................. 65

Table 22. Numerical results of velocity distribution for banks - Slabcamp Creek .......... 65

Table 23. Descriptive statistics of velocity for banks - Slabcamp Creek........................ 66

Table 24. Numerical results of velocity distribution for channel - Slabcamp Creek ....... 66

Table 25. Descriptive statistics of velocity for channel - Slabcamp Creek.................... 67

Table 26. Numerical results of shear stress distribution for floodplain - Slabcamp Creek

Table 27. Descriptive statistics of shear stress for floodplain - Slabcamp Creek ........... 69

Table 28. Numerical results of shear stress distribution for banks - Slabcamp Creek.... 70

Table 29. Descriptive statistics of shear stress for banks - Slabcamp Creek ................. 70

Table 30. Numerical results of shear stress distribution for channel - Slabcamp Creek.. 70

Table 31. Descriptive statistics of shear stress for channel - Slabcamp Creek ............... 71

Table 32. Numerical results of velocity distribution for floodplain - Brushy Creek ....... 77

Table 33. Descriptive statistics of velocity for floodplain - Brushy Creek ..................... 78 
Table 34. Numerical results of velocity distribution for banks - Brushy Creek 78

Table 35. Descriptive statistics of velocity for banks - Brushy Creek ........................... 79

Table 36. Numerical results of velocity distribution for channel - Brushy Creek .......... 79

Table 37. Descriptive statistics of velocity for channel - Brushy Creek ........................ 80

Table 38. Numerical results of shear stress distribution for floodplain - Brushy Creek.. 82

Table 39. Descriptive statistics of shear stress for floodplain - Brushy Creek ............... 83

Table 40. Numerical results of shear stress distribution for banks - Brushy Creek........ 83

Table 41. Descriptive statistics of shear stress for banks - Brushy Creek ...................... 83

Table 42. Numerical results of shear stress distribution for channel - Brushy Creek...... 84

Table 43. Descriptive statistics of shear stress for channel - Brushy Creek ................... 84

Table 44. The percentage of each area from total wet area - Slabcamp Creek ............... 88

Table 45. The percentage of each area from total wet area - Brushy Creek ................... 90

Table 46. Shear stress and velocity sensitivity and flow uncertainty error ................... 100

Table 47. Shear stress and velocity sensitivity and roughness uncertainty error........... 101

Table 48. Floodplain surface susceptibility to modeled shear stress with Manning $\mathrm{n}=$

0.07 based on Slabcamp Creek modeling results.................................................. 105

Table 49. Floodplain surface susceptibility to modeled velocity with Manning $\mathrm{n}=0.07$

based on Slabcamp Creek modeling results...................................................... 106 


\section{LIST OF FIGURES}

Figure 1. Slabcamp Creek, Location map..................................................................... 26

Figure 2. Slabcamp Creek's Location in Kentucky, USA ........................................... 27

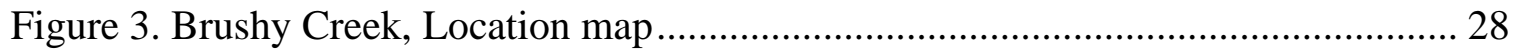

Figure 4. Brushy Creek's location in Kentucky, USA …........................................ 28

Figure 5. Sensitivity of Shear Stress to Discharge variation - Slabcamp Creek ............. 44

Figure 6. Sensitivity of Velocity to Discharge variation - Slabcamp Creek .................. 45

Figure 7. Sensitivity of Shear stress to Roughness variation - Slabcamp Creek ........... 46

Figure 8. Sensitivity of Velocity to Roughness variation - Slabcamp Creek.................. 47

Figure 9. Sensitivity of Shear Stress to Discharge variation - Brushy Creek ................. 53

Figure 10. Sensitivity of Velocity to Discharge variation - Brushy Creek ..................... 54

Figure 11. Sensitivity of Velocity to Discharge variation - Brushy Creek ..................... 55

Figure 12. Sensitivity of Velocity to Roughness variation - Brushy Creek .................... 56

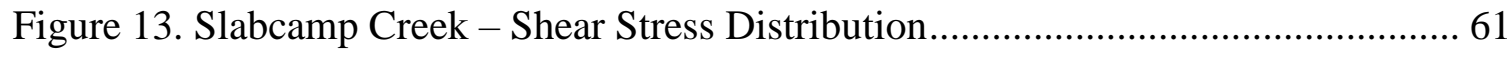

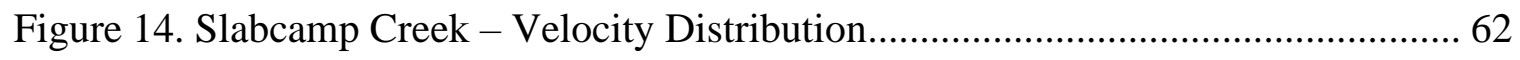

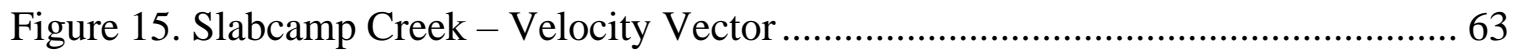

Figure 16. The percentage of area for different velocity categories for floodplain -

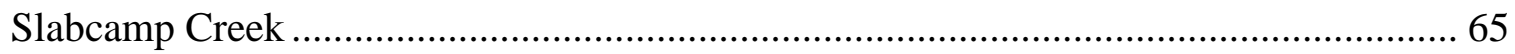

Figure 17. The percentage of area for different velocity categories for banks - Slabcamp

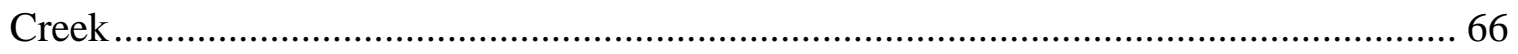


Figure 18. The percentage of area for different velocity categories for channel -

Slabcamp Creek

Figure 19. The cumulative percentage of area for different velocity categories for all parts

- Slabcamp Creek 68

Figure 20. The percentage of area for different shear stress categories for floodplain -

Slabcamp Creek 69

Figure 21. The percentage of area for different shear stress categories for banks -

Slabcamp Creek 70

Figure 22. The percentage of area for different shear stress categories for channel -

Slabcamp Creek 71

Figure 23. The cumulative percentage of area for different shear stress categories for all parts - Slabcamp Creek 72

Figure 24. Brushy Creek - Shear Stress Distribution 74

Figure 25. Brushy Creek - Velocity Distribution................................................. 75

Figure 26. Brushy Creek - Velocity Vector ......................................................... 76

Figure 27. The percentage of area for different velocity categories for floodplain -

Brushy Creek 78

Figure 28. The percentage of area for different velocity categories for banks - Brushy

Creek

Figure 29. The percentage of area for different velocity categories for channel - Brushy

Creek 80

Figure 30. The cumulative percentage of area for different velocity categories for all parts - Brushy Creek 81 
Figure 31. The percentage of area for different shear stress categories for floodplain -

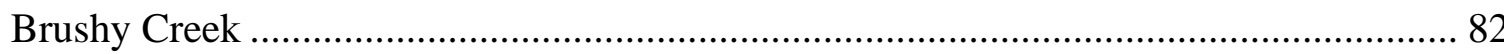

Figure 32. The percentage of area for different shear stress categories for banks - Brushy

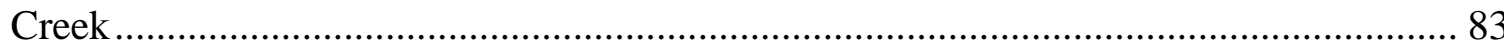

Figure 33. The percentage of area for different shear stress categories for channel -

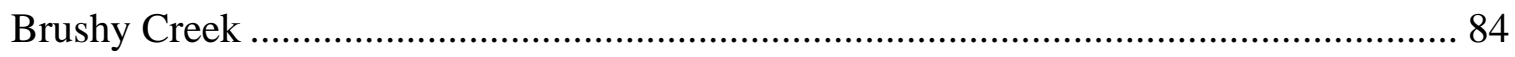

Figure 34. The cumulative percentage of area for different shear stress categories for all

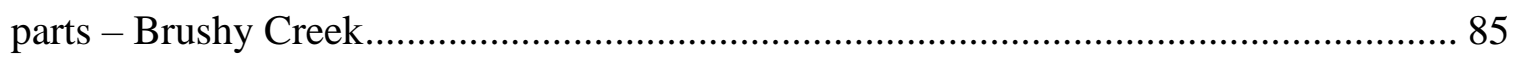

Figure 35. Eroded spots in Slabcamp Creek, Red polygons indicate area of erosion ...... 87

Figure 36. Eroded spots in Slabcamp Creek. Red polygons indicate area of erosion. ..... 88

Figure 37. Eroded areas in Brushy Creek. Red polygons represent areas identified as

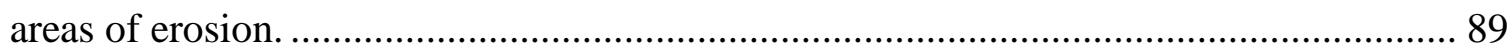

Figure 38. Eroded areas in Brushy Creek. Red polygons represent areas identified as

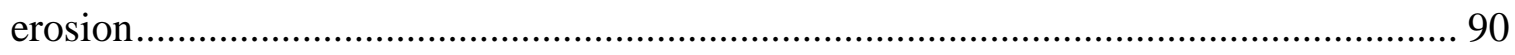

Figure 39. Banks \& Floodplains - Slabcamp Creek ................................................ 91

Figure 40. Banks \& Floodplains - Slabcamp Creek ................................................. 92

Figure 41. Banks \& Floodplains - Brushy Creek.................................................... 92

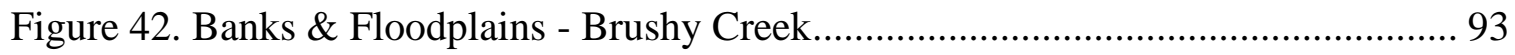

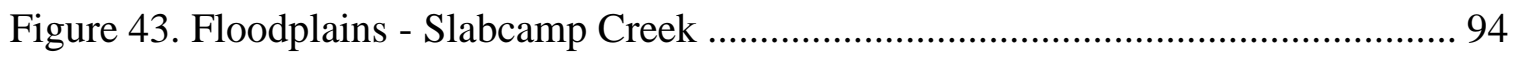

Figure 44. Floodplains - Slabcamp Creek …...................................................... 94

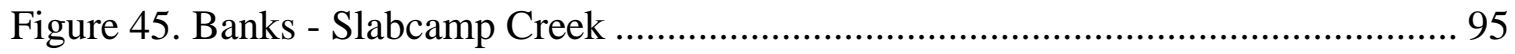

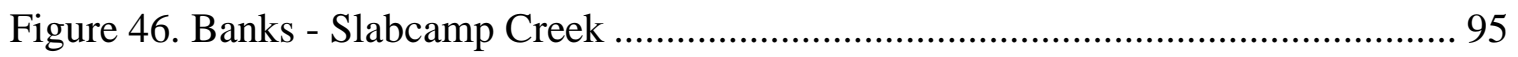

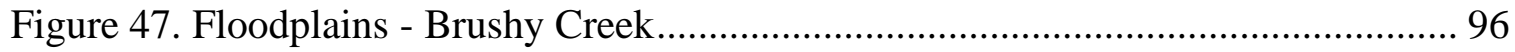




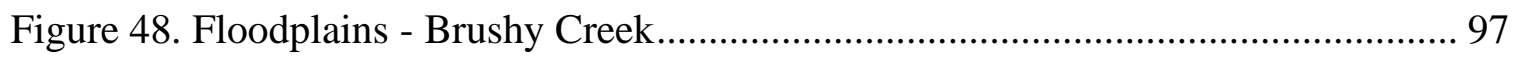

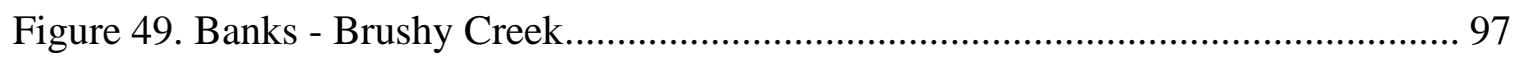

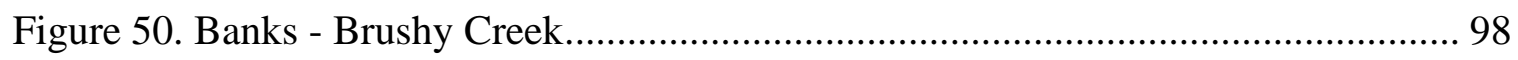

Figure 51. Percent Area of erosion variation with model shear stress for floodplains and bank. Box represents permissible stresses provided by Fischenich (2001).................. 105

Figure 52. Percent Area of erosion variation with model velocity for floodplains and banks. Box represents permissible velocity range for native grasses provided by

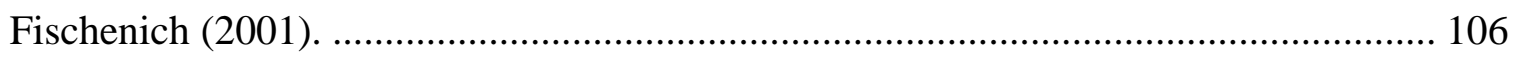




\section{CHAPTER 1}

\section{INTRODUCTION}

Among all kinds of ecosystems, those involved in flowing waters are the most degraded by human interventions [1]. Stream and floodplain morphology and hydrology are significantly influenced by humans, especially in densely populated regions [2, 3]. In recent years, both the reduction of impacts and the restoration of riverine ecosystems have received special attention from both practitioners and researchers due to the heightened awareness of the negative implications (e.g., economic, social, ecological losses) resulting from the stream degradation [4-6]. Specifically, in urban areas, the interest in stream restoration has considerably increased owing to its recreational, aesthetic, and public involvement benefits [7]. In general terms, stream restoration is considered as 'the return of a degraded ecosystem to a close approximation of its remaining natural potential'[4]. The term "stream restoration" has been used to describe a spectrum of activities from "passive restoration", which involves removal of land-use activities in riparian corridors and upstream watershed that may be causing degradation, to full reconstruction of the floodplain and valley bottom including shallow aquifers beneath the floodplain [8].

Although successful restoration of a stream has been shown to restore impaired ecological functions of the riverine environment, failures may result in considerable expenses and lead to further degradation of the riverine environment [9-12]. Several causes

of failure have been identified: excessive sediment deposition and burial bed control of 
bank structures by incoming sediment, channel bed degradation, rapid channel widening, rapid meander migration including channel migration away from bed control or bank structures, ineffective bed control or bank structures orientation [13].

Among different reasons for stream restoration failures, high channel stress and high velocity have been identified as the primary causes of failure [14]. The majority of failure of structures, typically used to protect the streambed or protect streambanks, occur where shear stress or velocity peaks $[13,15]$ near the structure. Generally, restoration components and structures in the regions indicating high shear stress or velocity are more susceptible to erosion and failure[16]. Insufficient bank protection has also been identified in regions with high shear stress[17].

Two-dimensional hydrodynamic models (2D models) are widely used by the hydraulic engineers to assess flooding, scour and erosion problems. These models provide a two-dimensional map of flow depth, flow velocity magnitude and directing, and boundary shear stress magnitude from which specific regions of inundated floodplains and channels can be evaluated for susceptibility to flooding and forces of the flowing water. Over the past several years, restoration designers have started to use 2D models to identify regions of channel, floodplain, and structures of the proposed project that indicate high shear stress and high velocity which may be vulnerable. The reliability of $2 \mathrm{D}$ models for the purpose of evaluating the susceptibility of restorations, however, has not been evaluated extensively.

The main purpose of this dissertation is to evaluate the reliability of the use of 2D models to predict regions of streambanks and floodplain that are susceptible to erosion. The effectiveness of these kinds of models in predicting the susceptibility of components 
to failure, particularly related to channel bed erosion, channel bank erosion, and floodplain surface erosion was studied and accuracy of the model for assessing the risk of having erosion was evaluated with field observations. Furthermore, the results of the model and data analysis have been used to evaluate existing recommendations for adequacy in determining the likelihood of erosion

To address the modeling reliability, this research assesses the ability of 2D Models to identify observed erosion in banks and floodplains based on comparisons of model predicted shear stress and velocity and field observations of erosion of the channel banks and floodplain. 


\section{CHAPTER 2}

\section{LITERATURE REVIEW}

Streams have affected and been affected by humans since the earliest civilizations [18]. Well-functioning stream ecosystems (physical, chemical processes) produce a range of valuable services for society (e.g., providing drinking water, supporting of fisheries, mitigating floods, and serving as recreational area). Past anthropogenic activity has adversely impacted stream ecosystems (e.g., water degradation, aquatic habitat reduction, and hydrologic and sediment transport alteration) in the United States [19]. While some of these activities have had a blatant disregard for stream ecological integrity (e.g., discharging hazardous chemicals into rivers), other activities have been motivated by a desire to "improve" streams for the benefit of humans (e.g., channelization and construction of levees for flood management, dam construction to control water quantities available, and diversions to irrigate cropland). As societies around the world come to appreciate the value of well-functioning stream ecosystems, solutions for repairing stream degradation caused by these activities have been sought.

Stream restoration, which is an umbrella term for a variety of activities (e.g., removal of invasive species, bank stabilization, channel realignment, habitat improvement), is one mechanism for repairing stream form and functions lost through earlier "command and control" policies [20]. Over the past twenty-five years, the number of stream restoration projects has increased in the U.S. and worldwide, with annual U.S. 
expenditures conservatively estimated at over one billion dollars [6]. Due to recent changes in mitigation policy [21] listing stream restoration as the preferred mechanism for mitigating stream impacts, the number of projects and annual expenditures are likely to increase.

Although stream restoration has similarities with other types of ecosystem restoration, it also has important distinctions. First, there is a divide between the practice and science of stream restoration. Although many academic researchers advocate for process-based, watershed-scale approaches in peer-reviewed literature [22-25], the majority of restoration designs are form-based and implemented at the reach-scale. For nearly all projects, there is an ad hoc element to design that is not always well-documented with knowledge more likely to be transferred orally or by nonpeer- reviewed publications. There is a need for capturing practitioner knowledge used in stream restoration to help interpret the decision-making process (i.e., evaluate how and why some design decisions are made and implemented) and to evaluate specific projects by identifying design (e.g., design tools used, design strategy), construction (e.g., design-build construction paradigm; contractor experience), and social factors (e.g., landowner education) that may have impacted stream restoration project success and/or failure.

Stream restoration often relies on the underlying assumption that physical manipulations of channel form (e.g., construction of pools; remeandering a channel) will lead to improved stream functions and services. According to Bernhardt et al., stream restoration projects were rarely monitored at the level required to understand the mechanisms responsible for their success or failure. This may partly be because of the high cost of monitoring and evaluation of that monitoring data required to develop an accurate assessment of cause. 
Project assessments, when performed generally focus on physical components of stream restoration, partly because they are the most straightforward to assess.

The scarcity of appropriate stream restoration project evaluations makes it difficult to determine which functions and services are being returned through stream restoration activities, and so the underlying assumption is not tested, and the successfulness of these activities often remains uncertain. Part of this uncertainty may be exacerbated by the difficulty of defining success and a vagueness over the definition of success (i.e. what aspects should be included in the evaluation). Fully functioning streams ecosystems (e.g., stream channel, riparian zone and floodplain) provide a variety of ecosystem functions (e.g., nutrient cycling, flood mitigation, regulation of stream flows and temperature, and groundwater-surface water exchange) and services (e.g., recreational and educational opportunities, commercial fishing, and pollutant abatement) that benefit society [2, 26, 27]. Anthropogenic actions of channelizing streams, altering surface and subsurface flow regimes, changing land uses, discharging chemicals, and introducing new species of flora and fauna have led to severely degraded streams and rivers in the US and worldwide [5, 26, 28, 29]. Physical and biological degradation has many forms including incised streambeds, disconnected floodplains, low geomorphic complexity, altered hydrologic processes, loss of native species, and spread of invasive species [28]. The majority of smallorder U.S. streams, which make up approximately ninety percent of US stream miles, have some level of biological impairment [29]. The most common water quality impairments in streams, by percent of miles affected, are pathogens (15\%), sediment (11\%), nutrients (11\%), organic enrichment/oxygen depletion (9\%) and habitat alterations (9\%) [19]. The 
leading sources of impairment include agriculture, atmospheric deposition, riparian disturbance and hydrologic modifications [19, 29].

\subsection{Stream Restoration Overview}

Stream restoration is an attempt to address this degradation. When broadly defined, stream restoration covers a wide range of activities (e.g., invasive species removal, channel realignment, habitat creation) performed to improve ecological, geomorphic and hydrological functions, mainly through use of physical structures and/or channel adjustments $[2,30,31]$. Although objectives considering social values are commonly present as well, they are generally not as well-defined [32]. In recent decades, the practice of stream restoration has increased, both in terms of the number of projects completed and the associated public and private expenditures as countries around the world try to find solutions for repairing past damage to these dynamic ecosystems and re-establish the values they produce and deliver; annual U.S. expenditures are conservatively estimated at over one billion dollars [6]. Despite the increasing number of projects, the ability of stream restoration to improve ecosystem integrity is still uncertain for a large percentage of projects due to a variety of factors (e.g., lack of post-project evaluations; difficulty defining success and the dynamic nature of stream ecosystems).

Uncertainty in stream restoration leads to a risk of failure to meet project objectives. The primary objective of most stream restoration designs is to promote or improve channel stability caused by anthropogenic disturbance. Unstable channels can create a number of problems, including: (1) elevated turbidity levels in surface water drinking supplies; (2) excess sediment inputs leading to downstream aggradation which may destroy aquatic 
habitat, reduce the functionality of infrastructure, and increase flooding; (3) channel incision, bank collapse, and retreat resulting in infrastructure and property damage; (4) shifting bed sediments resulting in loss of habitat; and (5) disconnection of the channel from the floodplain causing a reduction in nutrient cycling and increased shear stresses in the channel. It is apparent that the failure of a stream restoration design to meet its primary objective of channel stability can have considerable economic and environmental impact.

Understanding uncertainty is important in decision-making and may improve the likelihood of success in stream restoration projects. In addition, good design practice requires the application of verification procedures to check channel stability and develop design procedures that account and/or reduce uncertainty. Designs that incorporate analysis of physical, hydraulic, and sediment transport data and advanced verification procedures and may have a lower uncertainty and likelihood of failure [33]; however, this has not been demonstrated. A low-risk stream restoration design requires validating method assumptions, specifying site-specific limitations that introduce uncertainty, incorporating uncertainty in the decision-making process during the design phase, and reducing uncertainty by verifying the final design. It is hypothesized that the uncertainty, and thereby risk, in stream restoration can be reduced by acknowledging design method assumptions and limitations and incorporating hydraulic modeling as a design and verification tool.

Many of the sources of uncertainty involved with restoration design are difficult to quantify and incorporate into a model predicting system response [13]. Due to this complexity, uncertainty is rarely reported and incorporated within design procedures [34]. 


\subsection{Defining Stream Restoration}

The term stream restoration is used, formally and colloquially, by government agencies, researchers, environmental consultants, not-for-profit organizations, and the general public to describe a variety of activities performed to improve stream function. Multiple definitions and uses of the term stream restoration have been published by several researchers [2, 5, 35] stream restoration organizations [36] and national agencies [26]. Definitions vary based on disciplinary influence, role of historical conditions, ecosystem functions and processes considered, and the degree to which functions must be improved. The term ranges from being narrowly (e.g., return channel to a historic pre-disturbance state) to broadly defined (e.g., enhancing stream function), and including many definitions in between (e.g., returning selected ecological functions). The stream ecosystem functions returned through restoration depend on site-specific conditions (e.g., surrounding land use, degree of degradation) and the types of actions taken.

There is no consensus of which activities should be defined as restoration. The range of activities that may qualify as restoration, depending on definition used, includes planting riparian vegetation, installation of in-stream habitat structures, bank stabilization, and species reintroduction. Stream restoration is often used as the umbrella term for several channel manipulation techniques including restoration, rehabilitation, revegetation, bank stabilization, and enhancement $[2,25]$. Some researchers/practitioners distinguish between these activities, arguing that benefits to the stream differ significantly among these activities. It should be noted that even among researchers who differentiate these activities (e.g., distinguish between stream restoration from stream rehabilitation) definitions vary.

For example, Shields et al. (2003) defines stream rehabilitation as returning a "degraded 
stream ecosystem to a close approximation of its remaining natural potential", which is narrower than Kauffman et al. (1997)'s definition of "making the land useful again after natural or anthropogenic disturbances $[2,25] . "$

The word restoration itself may be problematic as it implies returning a stream ecosystem to its pre-disturbance condition, which may no longer be desirable or practical [37] as streams are dynamic ecosystems that have multiple pre-disturbance states and present-day constraints (e.g., altered hydrologic processes). Some definitions require that the channel manipulations lead to a self-sustaining stream, while others allow for adaptive management and periodic human maintenance.

Definitions often do not address all components of stream ecosystems. Activities addressing a single function or structural component (e.g., bank stabilization/reducing erosion) may be considered restoration by some individuals and agencies, whereas others have a narrower definition requiring a more holistic approach (e.g., addressing social, ecological and physical processes). Many stream restoration definitions do not consider human communities as a component of stream ecosystems, leading practitioners to ignore important cultural and social anthropogenic interactions with streams when designing and evaluating restoration projects [26].

Few definitions mention the role of groundwater-surface water interactions with respect to stream restoration, despite studies demonstrating the effect hyporheic exchange and groundwater can have on stream water quality and aquatic habitat. As stream restoration projects are implemented to achieve mitigation obligations, a single-function or purely structural objective may lead to decreased overall ecosystem functions and services provided by streams [4, 24]. 
As the practice and science of stream restoration increases, it is important to develop a more consistent definition. Too broad a definition allows activities with little improvement in ecological or socio-economic functions to be defined as restoration and possibly used as mitigation for adverse stream impacts. Too narrow a definition may result in too few projects able to qualify as restoration and discourage the practice. Although terms, such as rehabilitation, more accurately describe the activities that often occur under the guise of stream restoration, its use in international societies (e.g., Society of Ecological Restoration) and practice makes it challenging to change stream restoration to stream rehabilitation. It is possible, however, to define how restoration is currently being used in practice and identify sources of variation.

\subsection{Stream Restoration Design and Evaluation Challenges}

\subsubsection{Uncertainty in Design Approaches}

Army Corps of Engineer projects for flood mitigation were primary agents of stream manipulation in the U.S. prior to 1990 and have completed thousands of projects throughout the country including dam and levee construction, stream channelization, and stream stabilization. Until recent decades the primary means of stream stabilization involved installation of concrete trapezoidal channels, concrete weirs, riprap channels, and gabion baskets [38]. However, in the late 1980s Dave Rosgen, a former employee of the U.S. Forest Service developed an alternative approach to stream stabilization called Natural Channel Design (NCD). Natural Channel Design is best known for its natural approach to restoration where channel dimensions of a "reference reach" within the same watershed or regions are reconstructed in the impaired reach and strategically placed natural materials 
(e.g., log vanes, root wads) are used to promote ecological recovery. The Rosgen classification system is also a component of $\mathrm{NCD}$, where dimensionless ratios are used to classify stream reaches, indicate the degree of impairment, and elucidate restoration strategies that will be successful at the impaired reach based on an evolutionary tendency of rivers to follow a predictable sequence of stream types following a disturbance [35]. The introduction of NCD was timely given unprecedented increases in public interest for environmental restoration and "natural" solutions. Since that time, exponential increases in stream restoration projects have occurred throughout the U.S. with NCD becoming the primary stream restoration approach endorsed by the federal agencies such as the Environmental Protection Agency, U.S. Fish and Wildlife Service, Natural Resources Conservation Service, and the U.S. Forest Service. However, critical evaluation of projects that employ NCD have not followed suit with project evaluation rarely being a requirement of restoration projects [5, 38-40] While Lave (2010) has examined reasons why the NCD approach is appealing to practitioners (e.g., ease of implementation, agency support), many of the social factors affecting the stream restoration design process have not been thoroughly investigated [41].

Several stream restoration techniques have become popular since the inception of NCD including construction of in-stream structures from natural materials to alter local hydrologic conditions. Log vanes, for example, reduce local bank stress and decrease toe erosion circumventing translational and cantilever streambank failure [35, 42, 43]. Riparian plantings can serve a similar function by increasing bank resistance to erosive shear forces via increased roughness along the streambank, which aids in energy dissipation, and by increasing tensile strength of the soil matrix [24, 44, 45]. Plantings 
above the top of bank also provide stability via root reinforcement and function as a filtration system for runoff from adjacent areas. Multifaceted stream restoration approaches that employ a combination of morphological reconstruction, in-stream structures, and riparian planting will likely be more successful than sole measures of bank stabilization and are believed to be more successful at achieving goals of increased water and habitat quality [46].

Despite the exponential growth of stream restoration in the last few decades, there has been little empirical evaluation to determine if stream restoration activities are improving stream structure and function [22-24, 47, 48]. Evaluation when performed often relies on physical monitoring criteria with the assumption that if the physical structure is repaired, then ecosystem functions and services (e.g., physical, ecological and social) will return as well [20]. Some studies, however, have indicated that little ecological improvement is occurring $[23,48]$. Social objectives of individual projects are rarely assessed [32]. In addition, both the design and construction of projects needs to be evaluated. For example, there is a difference between a project failing because of an inappropriate design and failing because the design was poorly implemented/constructed.

For instance, stream restoration in the Chesapeake Bay watershed typically has three primary goals: riparian management, water quality management, and streambank stabilization, yet only $5.4 \%$ conducted basic before and after surveys to determine project effectiveness [49]. Of the projects within the Chesapeake Bay watershed that did monitor project effectiveness, only $24 \%$ assessed the response of the physical structure of the restored reach over time. These statistics are startling considering exponential increases in project implementation [41, 49] but are not surprising in light of multiple barriers to 
monitoring such as lack of funding, time and personnel [39]. Future success of stream restoration relies on such evaluations to determine what works, what does not, and to provide potential explanations for project success or failure.

\subsubsection{Inadequate Post-project Monitoring}

Monitoring of stream restoration projects is necessary to evaluate the success of current techniques, provide valuable feedback for future projects/guidelines and apply adaptive management techniques [28]; ideally it requires that pre-project baseline data be collected as well as post-project data for a comparison to be possible.

Methods for monitoring project success have been proposed [5, 9, 39, 50]. Distilling these methods, however, into a feasible monitoring strategy may be difficult because of the large number of physical and biological responses that may be affected by restoration. Research that incorporates statistical analysis of monitoring results can be even more difficult because of constraints inherent to most restoration projects such as small sample size, lack of independence, and difficulty locating and accessing appropriate control sites [9]. In 2005 many stream restorations projects did not have a monitoring program; the National River Restoration Science Synthesis (NRRSS) database reports that of over 37,000 projects included only $10 \%$ have monitoring or assessment programs and the majority of these are not quantitative [6]. Bash and Ryan (2002) performed a survey of projects in Washington State and found just over half of surveyed projects had any monitoring program in place and that it usually is a voluntary program [39]. Davis et al. (2003) also reports that few urban post-rehabilitation projects have quantitative monitoring, especially with respect to water chemistry and biological integrity [51]. 
Over the last 10 years monitoring and assessment of stream restoration projects has advanced. Some kind of monitoring is now required on nearly all projects as part of federal and state permit requirements. Stream restoration projects completed as part of mitigation for private or public impacts typically must perform several years of monitoring that includes physical monitoring for channel stability, vegetation monitoring and habitat assessment. These monitoring criteria very according to many factors including the state, project objectives, and the impact of restoration activities. Monitoring for vegetation has become comprehensive with goals for maximum percentage of invasive species and minimum diversity of trees species allowed. Failure to meet the monitoring requirements can invoke a loss of mitigation credit and potentially require modification of restoration.

\subsubsection{Susceptibility of Failure}

Uncertainty leads to a risk of failure and so it is critical to acknowledged this in stream restoration activities. There are several broad categories of uncertainty that are common to any design process. These include model uncertainty, parameter uncertainty, randomness and human error. Models are used in the stream restoration process for two primary purposes: design and response predictions and there are no models that can accurately predict all of the responses to change in the physical system for all settings and conditions.

Therefore, varying degrees of uncertainty are associated with the use of these models. Model uncertainty is often the primary source of uncertainty [13]. A potential failure can be affiliated with a cause, a mode, and an effect, although these are sometimes very unclear and difficult to define in real-life situations [52]. A failure mode is the manner 
in which a system or system component may fail to meet design intent [53]. In the context of river and stream modification design, failure modes may bring about functional or structural failures, thereby jeopardizing project goals and objectives. Johnson and Brown (2001) show different failure modes based on experience, prior failures at other sites, and knowledge of channel adjustments [13]. They comprise of excessive deposition, degradation, rapid widening, channel migration, rapid meander migration, burial by incoming sediment, rapid lateral migration away from vane, erosion of opposite bank, ineffective angles and excessive scouring. Based on results for Bentley Creek Restoration project, rapid channel widening and sediment deposition due to the change in cross sectional geometry received the highest risk priority number.

Stream restoration project sites are often not prioritized by their likelihood of project success, but by socioeconomic constraints, perceived ecological condition, geographic location in the case stream mitigation credits, land-ownership (preference for public lands or limited number of property owners) and the community's perspective on project benefits [37]. Miller and Kochel (2010) proposed a conceptual framework based on geomorphic parameters for assessing likelihood of project success early in the design process by 1) eliminating high risk sites from consideration of channel reconfiguration, and 2) improving upon the implemented management strategies that are ultimately used. They suggest focusing on the causative factors/processes of stream impairment and allowing the channel to reach a new equilibrium state on its own will lead to higher success rates and less expensive stream restoration. Their "enhanced natural recovery" includes actions such as land acquisition and management, development of conservation easements, removal of 
livestock from channel, creation of riparian buffers, and application of bioengineering techniques for bank stability [37].

2.4 Use of 2D models in stream restoration

Modeling of flow features that are important in assessing stream habitat conditions has been a long-standing interest of stream biologists. Recently, they have begun examining the usefulness of two-dimensional (2D) hydrodynamic models in achieving this objective. Brown et al (2016) and Schwartz et al (2015) demonstrate how 2D models can be used to design and deliver process-based riffle-pool restoration $[54,55]$. They used 2D models to design a self-maintaining pool-riffle sequence based on the flow convergence and shear stress reversal hypotheses. Models were also used to assess erosion and deposition patterns in channel and on the floodplain following restoration [56-58] and for predicting maintenance (i.e. dredging) requirements [59] Two-dimensional models were also applied to designing and appraising floodplain restoration schemes. Clilverd et al (2016) successfully modelled surface and groundwater levels following embankment removal on a chalk stream [60]. Leyer et al (2012) showed how a 2D model could be used for reinstating floodplain forest whilst minimizing flood risk [61]. Hughes (2001) and Poulsen et al (2014) used modelling to assess erosion and deposition patterns [62, 63] and Wen et al (2013) for appraising floodplain management options [64].

Recently, one-dimensional and two-dimensional flows and mobile-bed numerical models have become useful tools for predicting morphological responses to stream restoration. Yong G. Lai in 2015 developed a coupled model that incorporates a processbased bank stability model within a recently developed two-dimensional mobile-bed model 
(SRH-2D) to predict bank retreat and compared the predicted and measured data, as well as results of a previous modeling study [65]. On one hand, the study demonstrates that the use of two-dimensional mobile-bed models leads to promising improvements over that of one-dimensional models. It therefore encourages the use of multidimensional models in bank erosion predictions. On the other hand, the study also identifies future research needs to improve numerical modeling of complex streams. The developed model is shown to be robust and easy to apply; it may be used as a practical tool to predict bank erosion caused by fluvial and geotechnical processes. Crowder and Diplas (2000) show the importance of including features potentially impacting flow such as boulders, root-wads and other obstructions when modelling streams for ecologically driven stream restoration schemes. Using a 2D model (RMA-2V) of a stream, they demonstrate the potential impact of boulders on flow depending on their location in the channel and provide the information about the flow patterns in the vicinity of these obstructions [66]. In another study, Pasternack et al. (2006) tested 2D model (FESWMS) predictions on a river restoration scheme against measured depth, velocity and shear velocity. The errors were averaged $21 \%, 29 \%$ and $31 \%$, respectively. Depth error was mainly due to topographic survey errors, which in turn explained more than half of flow and shear velocity prediction error. In spite of these limitations, shear stress estimations were not significantly different from observed values and predicted habitat feature distribution at the $3-100 \mathrm{~m}$ (i.e. meso to macro habitat) scale was comparable to predicted outputs. Also, their numerical models are limited to channel types adhering to model assumptions and yield predictions accurate to $20-30 \%$. These models provide a useful tool for river restoration design and assessment, including spatially diverse habitat heterogeneity as well as for pre- and post-project appraisal [67]. 
Also, Pasternack et al. (2008) used a 2D hydrodynamic model (FESWMS) to study the impact of backwater effects on riffle pool formation and habitat quality for salmon. Model results indicated that a "reverse domino" mechanism can explain catastrophic failure and reorganization of a sequence of riffles based on the water surface elevation response to scour on downstream riffles, which then increases scour on upstream riffles [68]. John S. Schwartz et al. in 2015 used 2D hydraulic model (River 2D) for designing riffle pool sequences in straightened river reaches. for assessing the impact of trees growing on the bank face the 2D model was used to investigate the development of helical flows conducive to riffle development and maintenance. The analysis resulted in the removal of trees and widening of the channel where riffles were existed. Also, the model was used to assess bank stability and introduce reinforcements (root wads) where there is a chance that vulnerable to erosion. Finally, the model was used to map available habitats for three fish species after rehabilitation [55]. Poulsen et al. (2014) operated a 2D model (Mike 21) to evaluate the impact of channel and floodplain restoration of a straightened river on overbank sedimentation. A regression model was used to relate sediment deposition on the floodplain to the distance, velocity and depth to flow outlet predicted by the model. In 2004, Lange et al. employed a 2D model (HYDRO-AS-2D) in an urban river stretch to create habitat diversity for different kinds of fish species. Habitat suitability indices were incorporated in the model based on depth and flow velocity to anticipate changes in usable areas in an attempt to support river restoration design criteria [69]. The potential of a twodimensional hydrodynamic model (River 2D) as a restoration design tool has also been demonstrated by Schwartz (2004) for high-flow habitat in low-gradient Midwest streams. Based on their conclusion, a 2D model seems to be a necessary restoration design tool to 
improve the complexity of lateral fluvial habitats [70]. The numerical results of the restoration of the Broye Delta in Switzerland conducted by Bollaert (2014) illustrated that a highly dynamic and active morphological area may be generated via both sediment transport during floods in the Broye River and head cut erosion of the delta by wave impact during storm events on the Lake of Morat [71]. In a methodological paper, Wheaton et al. (2004) used 2D models to generate maps of depth and velocity, that can be converted into habitat suitability maps for scenario testing. In this work, habitat suitability is calculated using Habitat Suitability Curves (HSC), which relate density of species to depth and velocity. The limitations of the Wheaton's approach include that (i) HSC curves are based on averaged values for depth and velocity around observed habitats, and (ii) other habitat attributes, such as the presence of nearby refuge and resting areas, are not accounted for in habitat suitability maps [72]. In 2013, Wen et al. constructed a 1D/2D coupled hydrodynamic model (MIKE FLOOD) at fine spatial resolution $(30 \mathrm{~m})$ for the South Marshes to evaluate the impacts of channel change on flow distribution, both within channels and on the floodplain. In this research, three scenarios were considered and simulated that represented the baseline (i.e. no change to the current channel depth), worsening (i.e. continuous erosion leading to deepened and built-up channels) and improved (via channel stabilizing etc.). Low, medium and high flows were used to compare the flow distribution and inundation extent for these three scenarios. The results demonstrated that substantial differences existed in flooding patterns with respect to river flow distribution, flow breaking locations into floodplain, and inundation extents, even for low flow conditions. They reported that the biggest changes were observed for medium flow. With this study, Wen et al. could demonstrate that hydrodynamic models is a useful 
tool in floodplain restoration designs through comparing the outcomes of alternative remediating works and the outcomes of simulation works on wetland system hydrology and inundation patterns [73]. Pool and riffle design options (based on changes of width and depth for creating self-sustaining pool-riffle sequences) were also studied by Brown et al. in 2016 by using a 2D model (SRH-2D). As stated at theory, pool riffle sequences require to display flow convergence at riffles and flow divergence at pools and higher levels of shear stress in pools at high flow. In this work, the design options considered for pool-riffle restoration include (i) local channel widening, (ii) river bed augmentation (e.g. rock-riffles introduction), (iii) channel fluctuation both in width and depth (e.g. narrow shallow 'step' riffle with wide and deep pools), and (iv) out-of-phase fluctuation in width and depth (i.e. wide shallow riffles and deep narrow pools). The results indicated that widening or augmenting streams alone is less significant to restore processes that will help maintain integrity of pool riffle structure. They concluded that only wide shallow riffles over narrow and deep pools can fulfill the requirement of the flow convergence and shear stress reversal hypotheses [74]. Branco et al. (2013) used a 2D hydrodynamic modeling to find out the relationship between the increase in weighted usable area (WUA) generated by different boulder placement (BP) scenarios in a disturbed site and a widespread potamodromous cyprinid fish - the Iberian barbel (Luciobarbus bocagei) - as the target species. This modeling was validated by experiments in a full-scale experimental fish way with different bottom substrata arrangements as to explore the effects of boulders on barbel movements. The findings indicated the importance of placing instream boulders in fragmented systems, that enhances suitable habitat area and river connectivity. However, BP is required to be specifically designed for each case study based on a comprehensive evaluation of each site 
and target fish species [75]. To investigate the hydrological impacts of river restoration along a stretch of River Glaven, North Norfolk, UK, Clilverd et.al (2016) employed coupled MIKE SHE-MIKE 11 hydrological-hydraulic models. The results indicated that the removal of the river embankments led to physical geomorphological conditions, which allowed regular overbank flows and provided space for water to spill out onto the adjacent floodplain. Their simulation attempts also showed that the restoration increased riverfloodplain hydrological connectivity, generating a more disturbance-based riparian area that extended from the river towards the edge of the floodplain. Modeling can also be used to predict the ecological responses to variation in water table depth and duration of water surface, that results from floodplain restoration [60]. In 2004, Alfredsen et al. employed 2D hydraulic models (River2D \& SSIM) involving habitat preference curves to design a habitat enhancement scheme for Atlantic salmon and trout. Their study demonstrated modelling can serve as a potential tool to investigate critical habitat criteria such as depth and velocity [76]. In another research, Leyer et al. (2012) used a 2D model (FLUMEN) to identify and assess areas suitable for planting trees and reinstating floodplain forests, and to delineate areas with suitable flow velocities and low flood risk [61]. In 2004, Pasternack et al. conducted a research on using a 2D model (FESWMS) to assess the effect of different layouts of gravel augmentation in a depleted reach of a dam on habitat conditions for salmon, based on velocity and depth assessment. The results indicated that there was a good agreement between model predictions of depth and velocity and experimental data although velocities tended to be underestimated. The authors also found that the model did not predict well over created bars and riffles due to the quality of the Digital Elevation Model (DEM). They reported that although topographic survey data resolution was high 
(cf 1 point per $3.6 \mathrm{~m}^{2}$ ), the DEM software used did not predict a topography accurately representing the terrain. Using even an accurate DEM, the authors found that the model predictions in Large Wood Debris (LWD) were not accurate, and the model failed to predict accurately habitat quality metrics and location as well as potential for sediment entrainment [77]. 


\section{CHAPTER 3}

\section{METHOD}

\subsection{Introduction}

This study was completed using field data from two stream restoration projects in Eastern Kentucky. The reaches used in this study were part of a larger stream and wetland restoration projects funded by the Stream and Wetland Mitigation Program of Kentucky Fish and Wildlife Resources. Two-dimensional models were developed from detailed topographic surveys and other field data from both sites. Estimates of areas of bank erosion and floodplain erosion were developed from aerial surveys. Model results and the aerial surveys were used to develop relations between model hydraulic parameters and areas of observed erosion.

\subsection{Study Areas}

\subsubsection{Slabcamp Creek}

The first study area was part of the restoration on Slabcamp Creek. Slabcamp Creek is gravel bed stream located in the Morehead District of the Daniel Boone National Forest. The project reach is located east of Cave Run lake and southeast of Morehead in Rowan county, Kentucky (Figure 1). The drainage area of Slabcamp Creek is $0.74 \mathrm{mi}^{2}$, the general valley slope is $1.2-1.5 \%$. Slabcamp Creek is second-order stream in the study reach. General bank heights and channel width at the top of the bank in the as-built condition are 
approximately $0.55 \mathrm{ft}$ and $7 \mathrm{ft}$, respectively. The length of stream examined in this study is approximately $2000 \mathrm{ft}$. The restoration project was designed by the University of Louisville Stream Institute (ULSI) and constructed by Advanced Enterprises Inc. The design and construction were done in cooperation with the US Forest Service. Construction of Slabcamp Creek was completed in October 2011.

Observations of the morphology of Slabcamp Creek indicate that it was most likely relocated to the base of the hillsides and channelized over much of its length prior to 1900 , presumably as part of historical logging and/or agriculture practices. Restoration included relocation of the channel away from the hillside toes and reconstruction of a single-thread and branching channel reaches. A sinuous floodplain area was created within the valley bottom and cross-floodplain grade controls (logs 18 inches or greater in diameter) were installed in the underlying gravel. Single thread and branching channels were allowed to evolve in response to the natural growth of vegetation and flood flow scour and deposition of sediment. The Slabcamp Creek watershed is in the Eastern Coalfields Physiographic Region. 


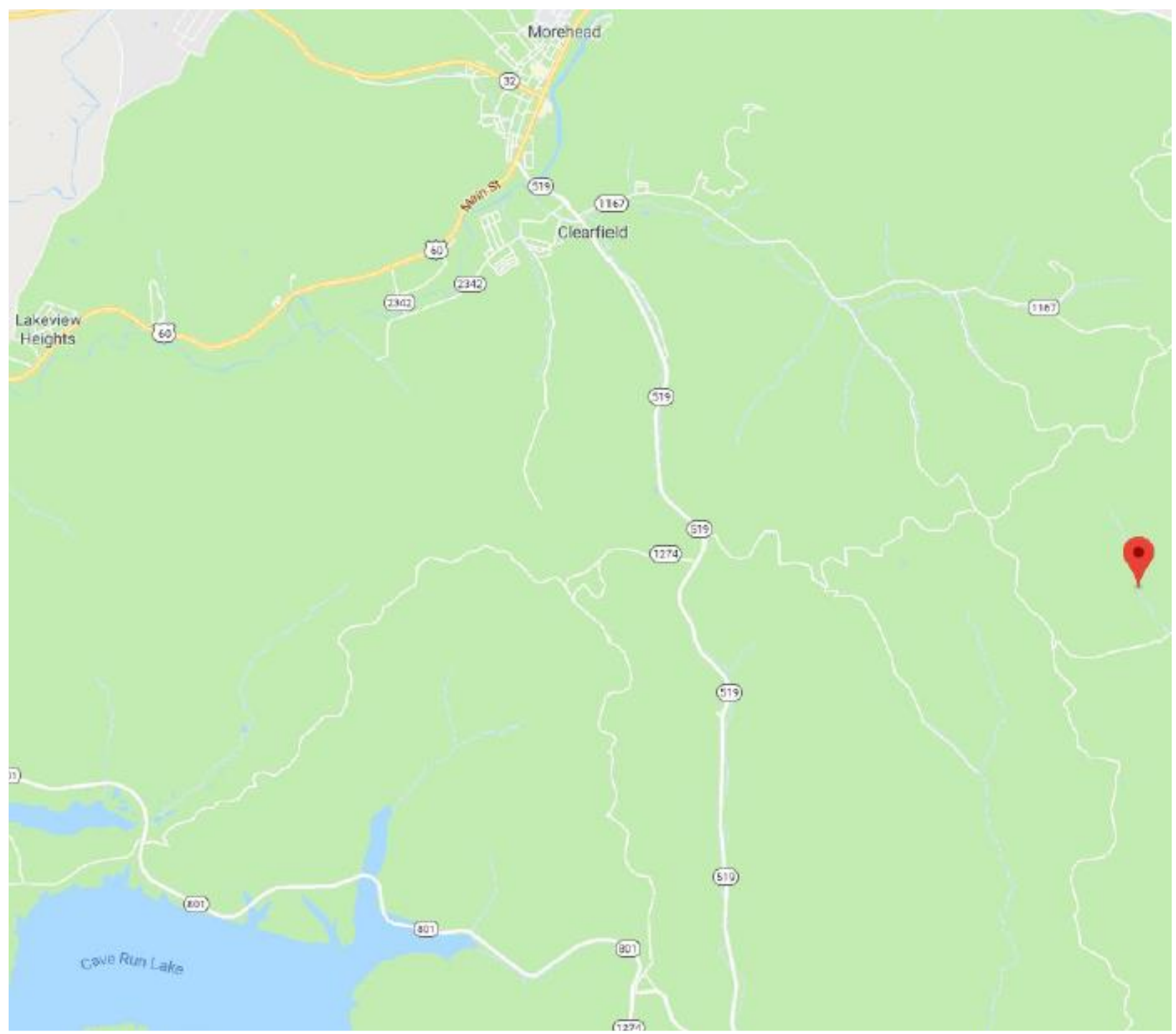

Figure 1. Slabcamp Creek, Location map 


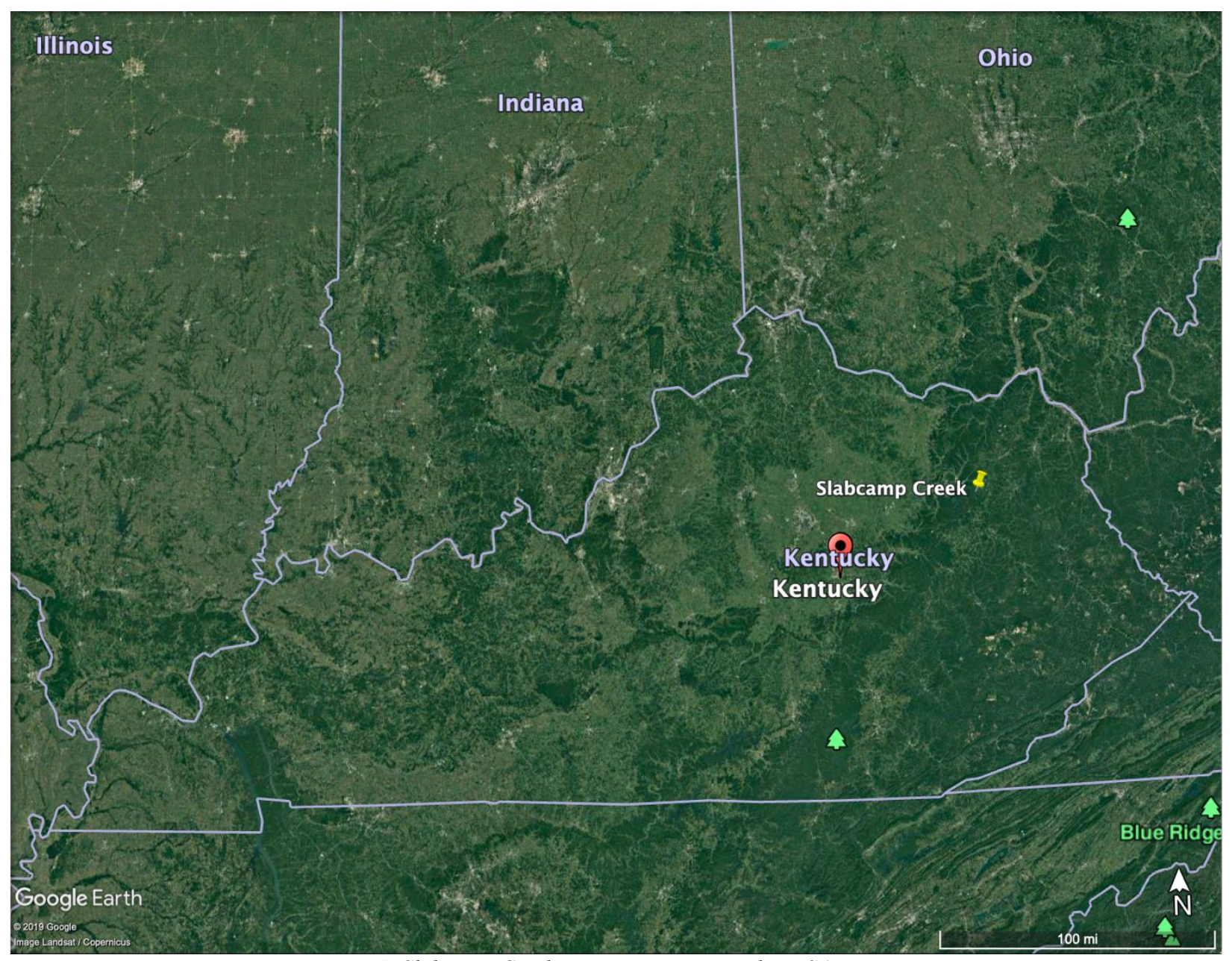

Figure 2. Slabcamp Creek's Location in Kentucky, USA

\subsubsection{Brushy Creek}

The second study area was part of the restoration on Brushy Creek. Brushy Creek is a second-order gravel bed stream that is a tributary to Tygarts Creek in the Ohio River basin in Greenup county in North Eastern Kentucky (Figure 3). The Brushy Creek watershed is in the Eastern Kentucky Coal Fields Physiographic Region.

The drainage area of Brushy Creek is $8.47 \mathrm{mi}^{2}$, the general valley slope is 0.007 $\mathrm{ft} / \mathrm{ft}$, typical bank heights and channel widths at the top of the bank in the as-built condition are approximately $1 \mathrm{ft}$ and $22 \mathrm{ft}$, respectively. The length of stream examined in this study is approximately $2500 \mathrm{ft}$. 
Construction of Brushy Creek was completed on 2006 and it was monitored for one year due to widespread instability.
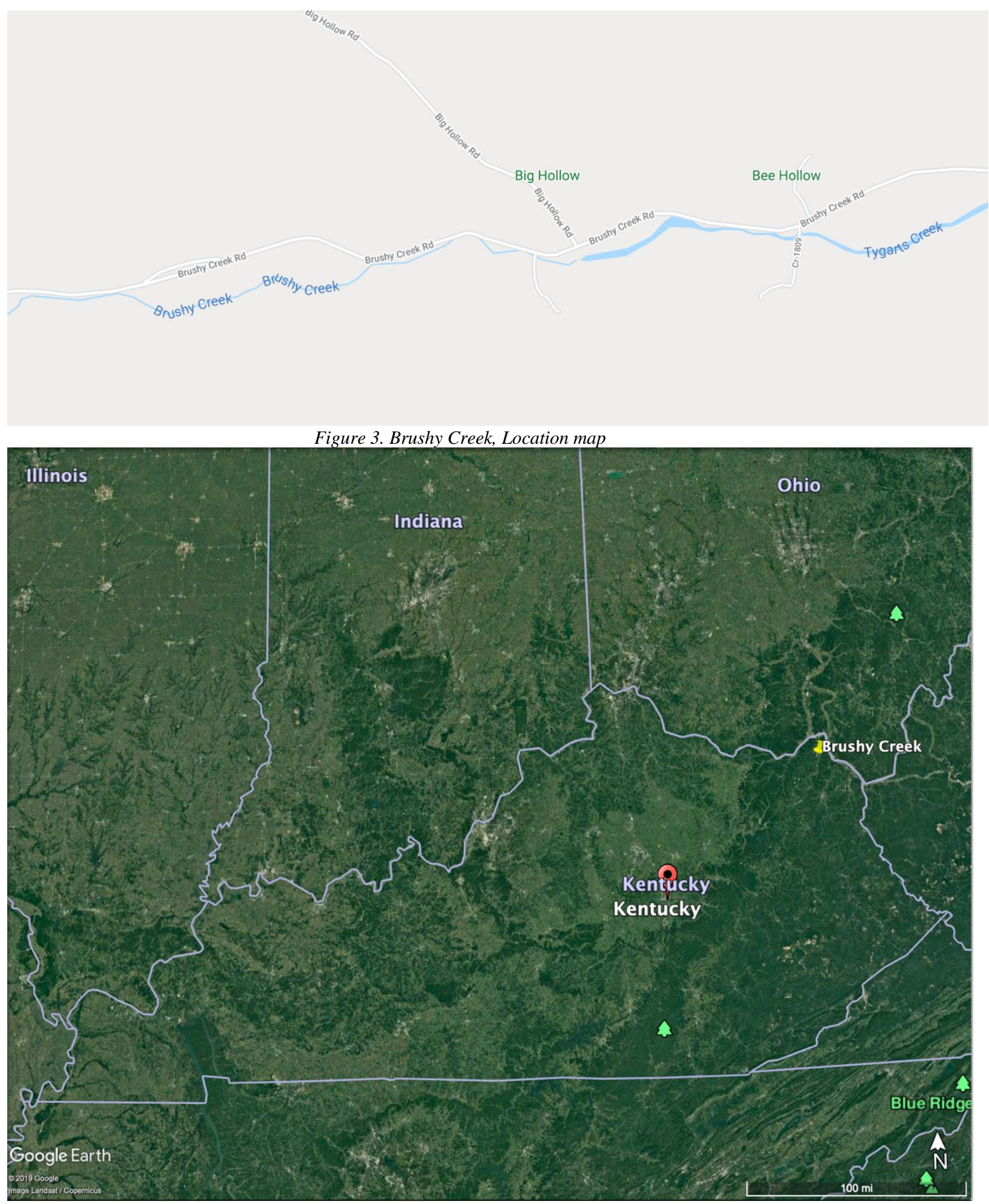

Figure 4. Brushy Creek's location in Kentucky, USA 


\subsection{D Models and Prediction of Bed Shear Stress and Velocity Magnitude}

Two-dimensional models were developed for each of the study areas. The surface water modeling systems (SMS) and TUFLOW were used to develop these models.

\subsubsection{Surface Water Modeling System (SMS)}

The Surface Water Modeling System (SMS) is a pre- and post-processor for modeling and design surface water projects. It is a comprehensive program for simulating one, two- and three-dimensional hydrodynamic modeling that includes modeling tools for setting up input data sets and output analysis. The entire process of modeling surface water from the import of topographic and hydrodynamic data to visualization and solutions analysis is included in the software package of SMS.

\subsubsection{TUFLOW}

The hydrodynamic model TUFLOW is a numerical model that simulates depth averaged, two- and one-dimensional free surface flow by solving the 2D Shallow Water Equations (SWE) using the Stelling Finite Difference Alternating Direction Implicit (ADI) scheme [78].

TUFLOW includes the ADI solver [78] which has two phases. There are two steps from breaking the phases which need to solve a tri-diagonal matrix. The momentum equation is solved in the Y-direction for the Y-velocities at the first step of phase 1. A predictor/corrector method is used for solving the equation which consist of two iterations. For the first iteration, the calculation begins column by column in the Y-direction. For the water levels and $\mathrm{X}$-direction velocities the equations of mass continuity and momentum in 
the X-direction are solved at the second step of phase 1 . The momentum equation is substituted into the mass equation and eliminating the $\mathrm{X}$-velocity and resultes in a tridiagonal equation. For calculating the velocities, the water levels are calculated and back substituted into the momentum equation. The start of phase 2 is similar to phase 1 with the first step using the $\mathrm{X}$-direction momentum equation and the second step using the mass equation and the Y-direction momentum equation [79]. TUFLOW was chosen for this research because it has been verified extensively, is a commonly used in water resource practice, and compares well with other models used by water resource engineers [80].

\section{TUFLOW Model Equations}

TUFLOW solves the 2D Shallow Water Equations (SWE). The vertical pressure distribution is assumed to be hydrostatic in the shallow water equations. This assumption results in small errors in the case of long and shallow waves (i.e. waves with a wavelength much larger than water depth), in which the vertical acceleration of fluid elements during the wave passage is small. The 2D Shallow Water Equations in the horizontal plane approximated in TUFLOW are:

2D Continuity Equation:

$\frac{\partial \zeta}{\partial t}+\frac{\partial(h u)}{\partial x}+\frac{\partial(h v)}{\partial y}=0$

Momentum Equations:

$$
\begin{gathered}
\frac{\partial u}{\partial t}+\frac{\partial u}{\partial x}+\frac{\partial u}{\partial y}-c_{f} v+g \frac{\partial \zeta}{\partial y}+g u\left(\frac{n^{2}}{h^{\frac{4}{3}}}+\frac{f_{1}}{2 g \partial x}\right) \sqrt{u^{2}+v^{2}}-\mu\left(\frac{\partial^{2} u}{\partial x^{2}}+\frac{\partial^{2} u}{\partial y^{2}}\right)+\frac{1}{\rho} \frac{\partial p}{\partial x} \\
=F_{x} \\
\frac{\partial x}{\partial t}+\frac{\partial x}{\partial x}+\frac{\partial x}{\partial y}-c_{f} u+g \frac{\partial \zeta}{\partial y}+g v\left(\frac{n^{2}}{h^{\frac{4}{3}}}+\frac{f_{1}}{2 g \partial x}\right) \sqrt{u^{2}+v^{2}}-\mu\left(\frac{\partial^{2} v}{\partial x^{2}}+\frac{\partial^{2} v}{\partial y^{2}}\right)+\frac{1}{\rho} \frac{\partial p}{\partial x} \\
=F_{y}
\end{gathered}
$$


where: $\zeta=$ water surface elevation $[\mathrm{L}], \mathrm{u}$ and $\mathrm{v}=$ depth averaged velocity in the $\mathrm{X}$

and $\mathrm{Y}$ directions $\left[L T^{-1}\right], \mathrm{h}=$ depth of water $[\mathrm{L}], \mathrm{t}=$ time $[\mathrm{T}], \mathrm{x}$ and $\mathrm{y}=$ distance in $\mathrm{X}$ and $\mathrm{Y}$ direction $[\mathrm{L}], \mathrm{cf}=$ Coriolis force coefficient, $\mathrm{n}=$ Manning's $\mathrm{n}, \mathrm{fl}=$ form (energy) loss coefficient, $\mu=$ horizontal diffusion of momentum coefficient, $\mathrm{p}=$ atmospheric pressure [FL2], $\rho=$ density of water [ML3], Fx and Fy $=$ sum of the components of the external forces (eg. wind) in $\mathrm{X}$ and $\mathrm{Y}$ directions.

\subsubsection{Model Input and Output}

TUFLOW requires a terrain model for the channel and floodplain geometry, discharge or water surface elevation at flux boundaries, and the roughness coefficient for the entire area that may be inundated. No stream gages were located on the stream or on streams in nearby watersheds. A synthetic three-stepped hydrograph was developed for the upstream boundaries of each model. The constant flow of each step of the hydrograph was held for one hour. The flow for the lower, middle and upper steps was based on flow estimates from USGS regression equations for the 2-, 10-, and 100-year recurrence intervals respectively. A water surface elevation representing the critical flow depth boundary computed by the TUFLOW model was used at the downstream end of the model as the downstream boundary condition. General model output included the water surface elevations, depth of flow, flow velocity, bed shear stress and Froude number.

\subsubsection{Topographic Data}

Accurate representation of topography, surface roughness, and flow are required to produce useful results in two-dimensional depth averaged models [81-83]. 2D Models 
require accurate digital elevation model (DEM) to represent the floodplain and channel surfaces $[83,84]$.

DEMs for both Slabcamp Creek and Brushy Creek were provided by University of Louisville Stream Institute and Kentucky Fish and Wildlife Resources, respectively. These DEMs were based on ground-based surveys soon after construction using Total Stations. The channel and floodplain DEMS were developed using standard topographic surveying techniques that include the use of break lines to represent features such as the top of the bank, toe of the bank, and thalweg of channels and other similar floodplain features. The survey for Slabcamp Creek was obtained on April 2010 after completing the project; so, it was considered as an As-built survey.

The surveys for the DEMs were completed using the State Plane Coordinate System, Kentucky North Zone (FIPS 1601), North American Datum of 1983 (NAD83) horizontal datum in units of survey feet, and the NAVD 88 vertical datum. Models spatial data was input in the same coordinate systems and projection.

\subsubsection{USGS Peak Flow Estimates}

Peak flow estimates (Table 2) for both sites were obtained from USGS Streamstats (https://streamstatsags.cr.usgs.gov/) which is based on USGS regional regression equations [85]. The peak flow estimates were computed for the downstream point of each study reach and used as the inflow boundary at the upper end of the reach. Watershed characteristics (Table 1) and the resulting peak flows (Table 2) were computed by the web-based utility from StreamStat and checked by available mapping and the USGS regression equations.

Table 1. StramStat Watershed Characteristics

\begin{tabular}{|l|l|l|}
\hline Parameter & Slabcamp Creek & Brushy Creek \\
\hline
\end{tabular}




\begin{tabular}{|c|c|c|}
\hline Drainage Area $\left(\mathrm{mi}^{2}\right)$ & 0.74 & 8.47 \\
\hline Mean Basin Elevation (ft) & 1140 & 867 \\
\hline Percentage of developed (urban) land (\%) & 4.82 & 5.27 \\
\hline Mapped stream flow-variability index & 0.7 & 0.877 \\
\hline Average percentage of impervious area (\%) & 1.04 & 0.55 \\
\hline Hydrologic Region & 2 - Upper east & 2 - Upper east \\
\hline
\end{tabular}

Table 2. Computed Peak Flows

\begin{tabular}{|c|c|c|c|}
\hline \multicolumn{2}{|c|}{ Slabcamp Creek } & \multicolumn{2}{c|}{ Brushy Creek } \\
\hline Return Interval & Value (cfs) & Return Interval & Value (cfs) \\
\hline 2 Year Peak Flood & 107 & 2 Year Peak Flood & 720 \\
\hline 5 Year Peak Flood & 169 & 5 Year Peak Flood & 1120 \\
\hline 10 Year Peak Flood & 216 & 10 Year Peak Flood & 1400 \\
\hline 25 Year Peak Flood & 280 & 25 Year Peak Flood & 1790 \\
\hline 50 Year Peak Flood & 331 & 50 Year Peak Flood & 2090 \\
\hline 100 Year Peak Flood & 385 & 100 Year Peak Flood & 2400 \\
\hline 200 Year Peak Flood & 441 & 200 Year Peak Flood & 2710 \\
\hline 500 Year Peak Flood & 518 & 500 Year Peak Flood & 3150 \\
\hline
\end{tabular}

\subsubsection{Flow Stage Observations}

The ULSI have collected stage data at Slabcamp Creek as part of the restoration monitoring. Similar data for the Brushy Creek site was not available. Water surface elevations at the Slabcamp site were monitored using a pressure sensor at a frequency of 15 minutes at one location in the study reach for approximately 5 years. Several floods occurred during the five-year monitoring period. The data from a flood in April 2015 was used in this study because it was larger than the others and it is assumed that the highest shear stresses on the channel banks and floodplain would have occurred during this flood. 


\subsubsection{Channel and Floodplain Roughness}

Initial estimates of Manning's roughness coefficients were selected for both Slabcamp Creek site and the Brushy Creek site based on matching site observations of vegetation and floodplain and channel geometric characteristics with photos from Chow [86]. The Manning roughness coefficients for both sites were initial estimated to be similar: 0.07 for the floodplain and 0.04 for the channel. These values were examined further in the model calibration and sensitivity analysis.

\subsubsection{Model Calibration of Flow and Roughness}

The model for Slabcamp Creek was calibrated using the peak stage observed in April 2015. Manning's $n$ values for floodplain and channel were selected based on typical values found in the literature. The roughness for the floodplain and channel were selected as 0.07 and 0.04 , respectively for both sites. The inflow that created the least difference between observed and computed water surface elevation at the observation point was selected for use in the modeling effort. Also, no surface water elevation observation was available for the Brushy Creek site.

\subsubsection{Model Sensitivity to Flow and Roughness}

The sensitivity of modeled shear stress and velocity magnitude values for both Slabcamp Creek and Brushy Creek were assessed by varying inflow and Manning $\mathrm{n}$ values. The effect of variation in input flow on the shear stress and velocity was evaluated through a series of three model runs in which the flow rate was varied, and all other model parameters were held constant. The flow corresponding to the 50-year, 100-year, and 200- 
year recurrence interval flows estimated from USGS regional regression equations. The effect of changes in floodplain roughness on shear stress and velocity was examined in a series of three runs in which the floodplain roughness was varied from 0.07, 0.08, and 0.09. In order to have a better understanding of results, the average and maximum of shear stress and velocity were calculated for different parts of the creeks (floodplain and channel).

\subsubsection{Uncertainty}

The main causes of uncertainty in predicted shear stress and velocity include uncertainty in flow, roughness parameters, and terrain. Other sources of uncertainty include the shallow water equation assumptions and turbulence modeling parameters.

Uncertainty in identifying and drawing erosion polygons occurred as a result of

- Overhanging vegetation and shadows

- Errors in aerial photo location of channels and surveyed channel bank lines

- misidentification of new channels and ruts

- regrowth of vegetation where erosion previously occurred

- resolution of digitization of polygons

Misidentification of erosion may have been caused by mortality of vegetation unrelated to high shear or velocity during large flood events: for example, burial by sediment deposition, herbicide related to invasive species management, foot traffic or animal trails, rerouting of channel because of channel blockage. Vegetation may have regrown over areas previously eroded. 


\subsection{Identification of eroded areas}

\subsubsection{High Resolution Aerial Photography}

ULSI collected high resolution aerial photographs using a drone at Slabcamp Creek. The photographs were obtained in March and May 2018. The resolution of the photographs was $0.07 \mathrm{ft}$. The photographs were used to identify the eroded patches at the banks and floodplain.

Google Earth Images were used at Brushy Creek to identify areas of erosion and deposition. The resolution of the photographs was $0.6 \mathrm{ft}$. In both studies the details were clear enough while the resolution was different.

\subsubsection{Processes to produce erosion polygons}

Eroded bank and floodplain areas were identified using aerial photographs. As-built bank lines were compared to areas of little or no vegetation to locate

- areas of bank erosion

- ruts in floodplain

- new location of channel compared to as-built location

- new branched channel segments

Based on the topography, the channel line and banks are obvious, and they can be overlapped on the aerial photographs and see where erosion has happened. The channel line and banks were provided during the survey for Slabcamp Creek and the bank lines were delineated in topography, but Brushy Creek didn't have the bank line on topography ;so, in order to delineate it several model runs with low inflow (such as $50 \mathrm{cfs}, 60 \mathrm{cfs}$ and,...) was carried out. 
SMS has a potential to overlap the as built and aerial photographs and then the researcher can draw polygons around the eroded spots. For this purpose, the researcher prefers to use drawn images since they are clearer, and it is easier to find the patches.

It is very hard to make sure that each polygon contains eroded points because in some locations there are vegetations around the channel and banks or due to the trees and their shadow; so, considering the erosion needs more efforts. Therefore, it would be better to have drown images in two different time of the year. One of them is taken in spring during which time vegetation don't grow up completely; so, the details can be seen better in the photos. In this way, we can check the eroded polygons twice and make sure to diminish the error of selecting them.

In this study, the eroded areas in the channel were not investigated and discussed because of presence of water in the channel it was difficult to find the eroded areas. Also, it is needed to have some information about sediment transport in the channel.

\subsubsection{Uncertainty}

However, there were some potential errors in identifying and drawing erosion polygons which have occurred as a result of:

- Overhanging vegetation and shadows

- Errors in aerial photo location of channels and surveyed channel bank lines

- misidentification of new channels and ruts

- regrowth of vegetation where erosion previously occurred

- resolution of digitization of polygons 


\subsection{Bed Shear Stress and Velocity vs Erosion Histograms}

Histograms for boundary shear stress vs eroded area and velocity magnitude vs eroded area were developed to show the total observed erosion for each interval of predicted boundary shear stress and velocity magnitude in the inundated areas. The histograms were based on the predicted value of bed shear stress and velocity of each square foot of inundated model domain and the existence of identified erosion on the floodplain surface or banks in the same location.

Histograms for both boundary shear stress and velocity vs the percent chance of erosion were developed by dividing the area eroded for each shear stress bin by the total area predicted to have the same range of shear stress. 


\section{CHAPTER 4}

\section{RESULTS}

\subsection{Slabcamp Creek Model Calibration}

During the calibration process, discharge was varied to obtain the best match between observed and simulated water levels at the Slabcamp creek. Results of the calibration runs (Table 3) indicate that observed flow was in the range of 400 cfs to 440 cfs. A flow rate of $400 \mathrm{cfs}$ was used for the input to the Slabcamp models in subsequent runs.

Table 3. Slabcamp Creek Calibration Results

\begin{tabular}{|c|c|c|c|c|c|}
\hline $\begin{array}{c}\text { Manning n } \\
\text { (Channel) }\end{array}$ & $\begin{array}{c}\text { Manning n } \\
\text { (Floodplain) }\end{array}$ & $\begin{array}{c}\text { Discharge } \\
(\mathrm{cfs})\end{array}$ & $\begin{array}{c}\text { Observed WSE } \\
(\mathrm{ft})\end{array}$ & $\begin{array}{c}\text { Computed WSE } \\
(\mathrm{ft})\end{array}$ & $\begin{array}{c}\text { Residual } \\
\text { Value (ft) }\end{array}$ \\
\hline 0.04 & 0.07 & 331 & 922.82 & 922.53 & -0.29 \\
\hline 0.04 & 0.07 & 385 & 922.82 & 922.70 & -0.12 \\
\hline 0.04 & 0.07 & 400 & 922.82 & 922.75 & -0.07 \\
\hline 0.04 & 0.07 & 441 & 922.82 & 922.87 & 0.05 \\
\hline
\end{tabular}

The 50-, 100-, and 200-year flows computed for the Slabcamp study reach were $331 \mathrm{cfs}, 385 \mathrm{cfs}$ and $441 \mathrm{cfs}$, respectively. $400 \mathrm{cfs}$ was selected for the inflow for the upstream boundary condition as an estimate of 100-year flow. 


\subsection{Model Sensitivity Analysis Results}

\subsubsection{Slabcamp Creek}

Statistics that show the significance of the variation of shear stress and velocity with flow from the estimated 50-year flow (331 cfs) to the estimated 200-year flow (441 cfs) were developed and also the effect of Manning $n$ variations in floodplain from 0.07 to 0.09 on the shear stress and velocity were evaluated (Figure 5 through Figure 8 and Table 4 through Table 11).

As anticipated, increasing inflow magnitude increases the shear stress magnitude. However, the maximum values in regions of the floodplain and channel with the highest shear stress do not vary substantially in the discharge range examined. Higher stress regions of the restoration were less different with $16 \%$ and $15 \%$ change in flows that are in the range of a 100-yr recurrence interval flow for the Slabcamp Creek and Brushy Creek site, respectively. This indicates that regions susceptible to high stress may be identified through a large range of flows that would typically be used to evaluate susceptibility.

As it can be seen, the shear stress is sensitive to the discharge variation, but the difference between three inflow magnitudes is more consistent in the left part of the floodplain. In the right part of the floodplain, the shear stress between the distance $44 \mathrm{ft}$ through $62 \mathrm{ft}$ is not as sensitive as the shear stress between the distance $120 \mathrm{ft}$ to $130 \mathrm{ft}$ and $74 \mathrm{ft}$ to $78 \mathrm{ft}$. the maximum amount of shear stress occures at the channel banks and because of the difference between the roughness in the channel and floodplain there is a sudden decrease and increase at the left floodplain and right floodplain (Figure 5). Moreover, the average value of the shear stress for the left part of the floodplain for 100 -yr flow is 0.134 
psf more than the 50-yr flow and 0.177 psf less than 200-yr flow, while those differences for the right side of the floodplain is 0.194 psf and 0.203 psf, respectively (Table 4).

Unlike the shear stress, there is a consistent variation among three discharges for velocity at both sides of the floodplain instead of the distance $44 \mathrm{ft}$ through $62 \mathrm{ft}$. the maximum amount of velocity has happened between the channel and bank for three of them (Figure 6). The differences between the average value of the velocity for 50-yr flow, $100-\mathrm{yr}$ flow and $200-\mathrm{yr}$ flow are $0.216 \mathrm{fps}$ and $0.324 \mathrm{fps}$ for the left floodplain and 0.285 fps and 0.238 fps for the right floodplain (Table 6).

Variation in the roughness of the floodplain had a significant effect on the magnitude of shear stress in the region of highest shear stress in the floodplain and in the bed of the channel. While an increase in stress of the floodplain with the increased roughness of the floodplain was expected, the decrease in channel shear stress with increases in floodplain roughness was unexpected.

In the left side of the floodplain with increasing the roughness there is not much differences between shear stress while in the right part of the floodplain the variations are nearly steady. As it was mentioned before, there is an unexpected alteration around the channel and the maximum of shear stress has occurred at the banks, but the changes among them are more than the situation that the discharge had been increased. Although the roughness in the channel were the same for the sensitivity analysis, with raising the roughness in floodplain shear stress in the channel has been dropped (Figure 7). It can be seen that the average of shear stress in the left side for the first and second roughness $(0.07$ $\& 0.08$ ) are very close and their difference is $0.066 \mathrm{psf}$, but it increases to $0.118 \mathrm{psf}$ for the 
other ones $(0.08 \& 0.09)$. However, this trend is not the same for the right side and those differences are $0.169 \mathrm{psf}$ and $0.176 \mathrm{psf}$, respectively (Table 8).

In the right part of the floodplain between the distance $38 \mathrm{ft}$ through $46 \mathrm{ft}$ and in the most part of the left side velocity is very sensitive to the changes in roughness, but in the other locations of the right floodplain there is less changes among graphs and even in some distances they are in the nearly same curve (Figure 8). Also, this trend can be seen in their average values of velocity (Table 10).

As anticipated, increasing inflow magnitude increases the average and peak values of shear stress magnitude in the channel and floodplains (Figure 5, Table 4 and Table 5). The variation of approximately $27 \%$ in flow (14\% less than the 100 year flow for the 50yr flow to $13 \%$ higher than the 100 year flow for the $200 \mathrm{yr}$ event) caused a total increase in channel average stress by approximately $4.3 \%$ and increases in floodplain average stress by $23.4 \%$ and $37.9 \%$ in the left and right floodplains, respectively. The variation in maximum shear stress for the same variation in flow is $10.0 \%, 12.4 \%$ and $11.1 \%$ for the channel, left floodplain and right floodplain, respectively.

Likewise, increasing inflow magnitude increases the average and peak values of velocity magnitude in the channel and floodplains (Figure 6, Table 6 and Table 7). The variation of approximately $27 \%$ in flow (14\% less than the 100 year flow for the $50-\mathrm{yr}$ flow to $13 \%$ higher than the 100 year flow for the $200 \mathrm{yr}$ event) caused a total increase in channel average velocity by approximately $7.0 \%$ and increases in floodplain average velocity by $16.8 \%$ and $21.7 \%$ in the left and right floodplains, respectively. The variation in maximum velocity for the same variation in flow is $6.48 \%, 7.87 \%$ and $7.28 \%$ for the channel, left floodplain and right floodplain, respectively. It is interesting that the variation 
in maximum shear stress and velocity in all three regions was less than $13 \%$ and $8 \%$, respectively, for a $27 \%$ change in flow.

As anticipated, increasing floodplain roughness increased the average and peak values of shear stress magnitude in the floodplains (Figure 7, Table 8 and Table 9). The variation of approximately $25 \%$ in Manning n (0.07 to 0.09$)$ resulted in a total increase in floodplain average stress of $14.0 \%$ and $18.0 \%$ in the left and right floodplains, respectively. The channel stress, however, decreased by $16.4 \%$. This is an unexpected result, since increasing roughness on the floodplains is likely to cause a transfer of flow to the channels where roughness was not changed, increasing channel velocity and energy dissipation resulting in high shear in the channel. However, the opposite result occurred. Average channel shear stress decreased significantly. The variation in maximum shear stress for the same variation in $\mathrm{n}$ values is $-7.7 \%, 14.4 \%$ and $10.0 \%$ for the channel, left floodplain and right floodplain, respectively. The maximum channel shear decreased with increased floodplain roughness similar, although not as much, to the average channel shear stress.

Increasing Manning $\mathrm{n}$ decreased the average and peak values of velocity magnitude in the channel and floodplains (Figure 8, Table 10 and Table 11). The variation of approximately $25 \%$ in Manning n (0.07 to 0.09$)$ resulted in a total change in average velocity by $20.4 \%, 6.5 \%, 10.3 \%$, for channel, left floodplain, and right floodplains, respectively. The maximum velocity for the same variation in roughness decreased by $7.7 \%, 14.4 \%$ and $10.0 \%$ for the channel, left floodplain and right floodplain, respectively. It is interesting that the maximum velocity in the channel decreased with increased roughness of the floodplains even though the channel roughness was not changed. 


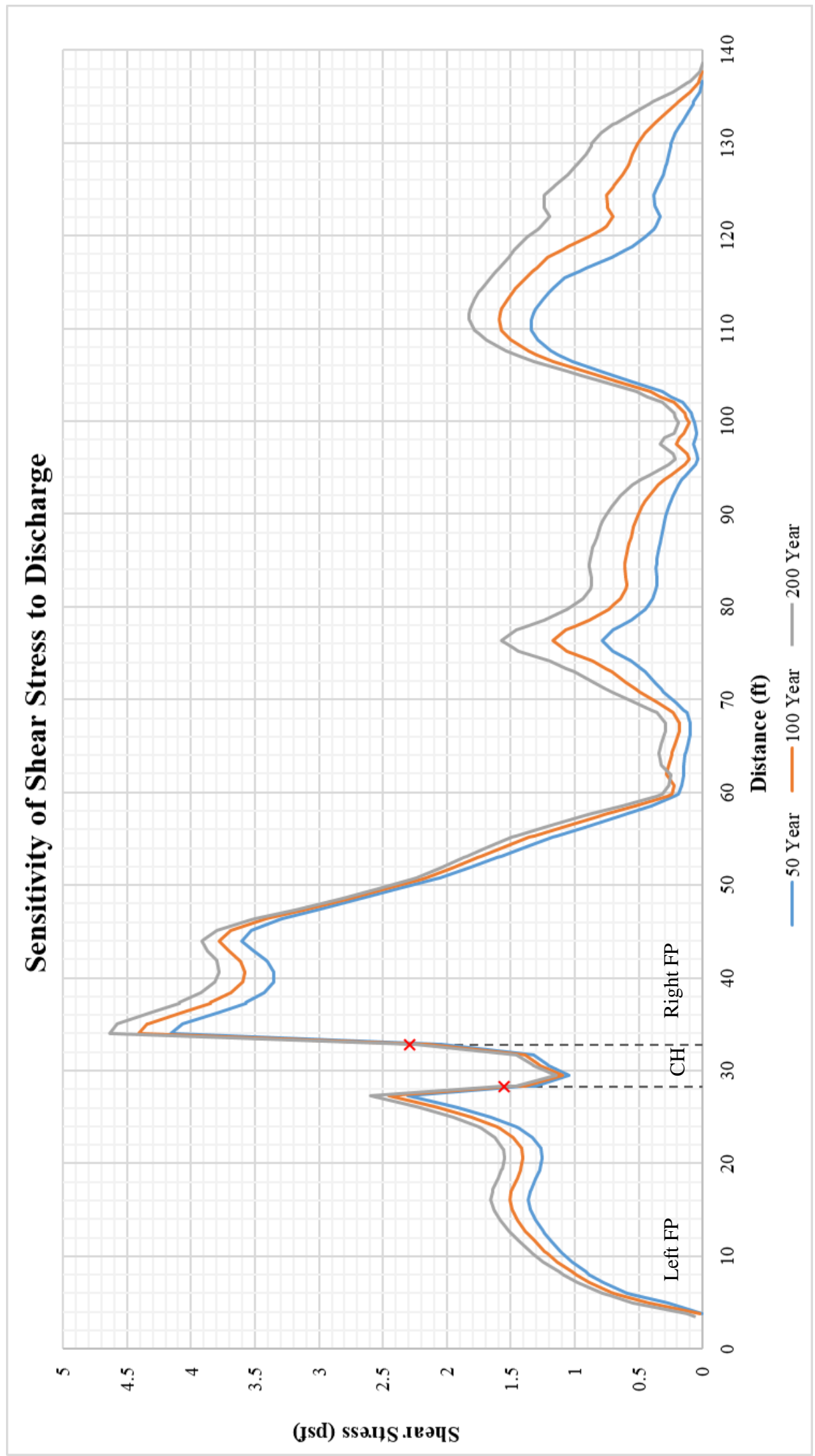

Figure 5. Sensitivity of Shear Stress to Discharge variation - Slabcamp Creek 


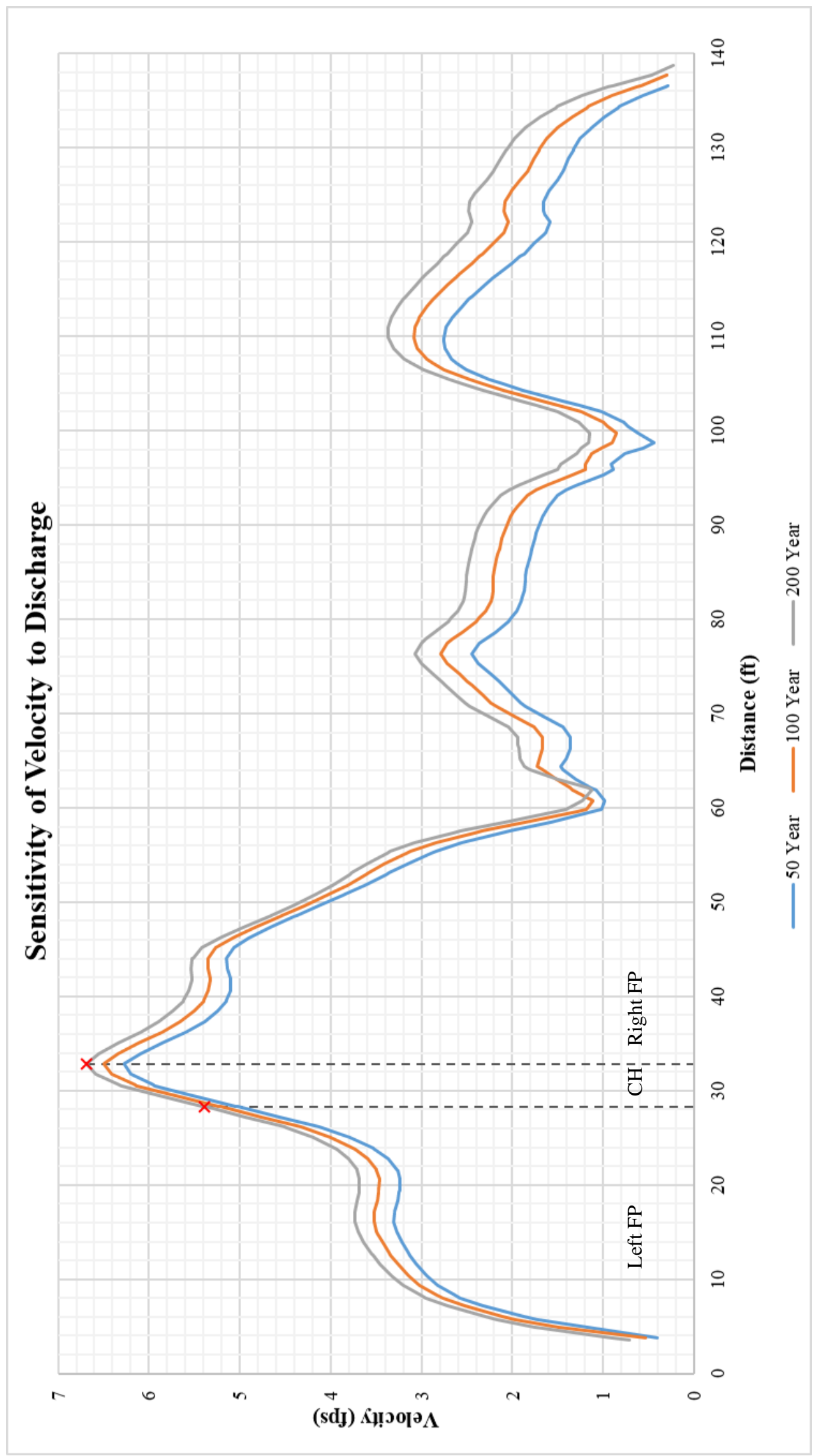

Figure 6. Sensitivity of Velocity to Discharge variation - Slabcamp Creek 


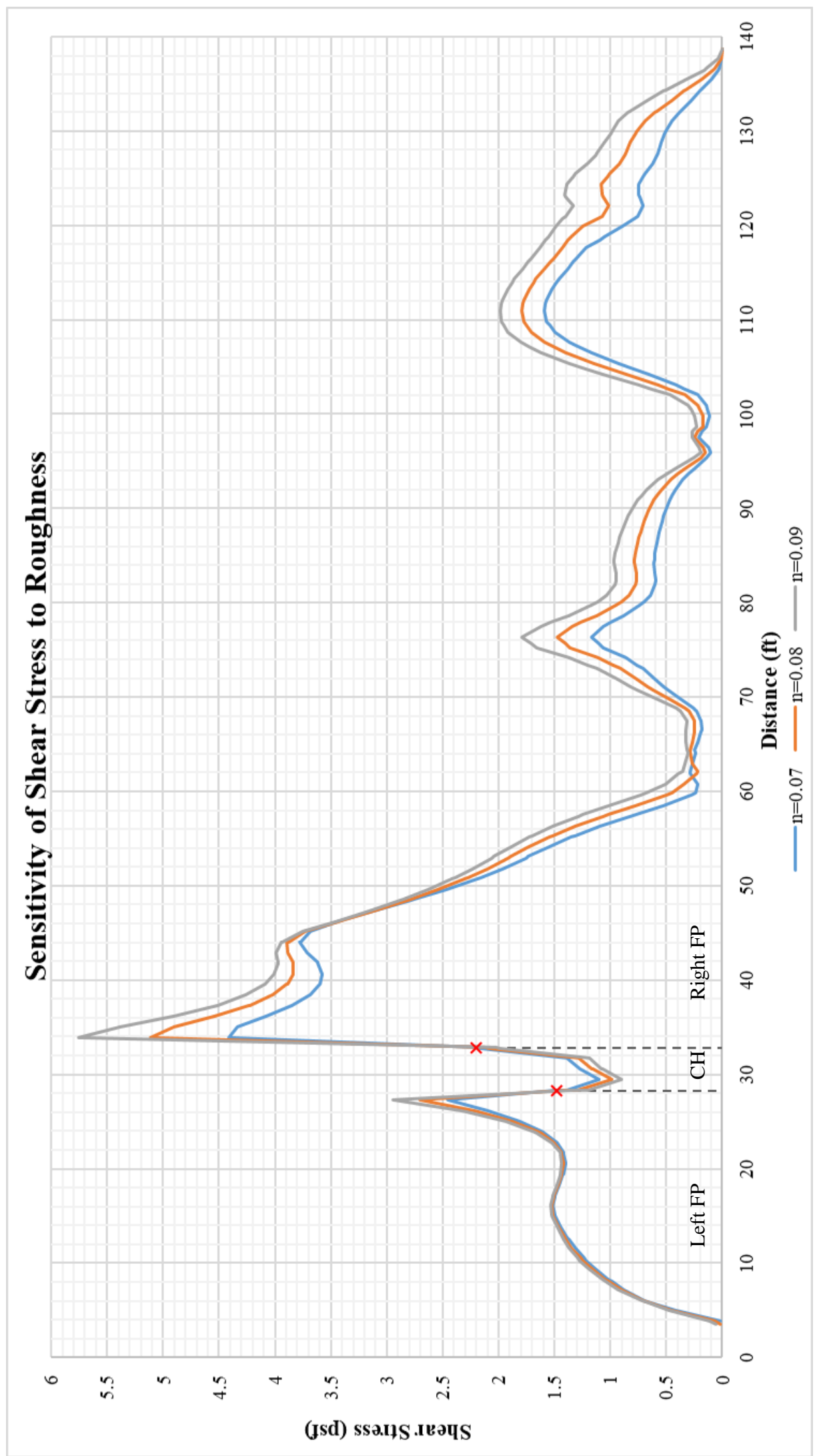

Figure 7. Sensitivity of Shear stress to Roughness variation - Slabcamp Creek 


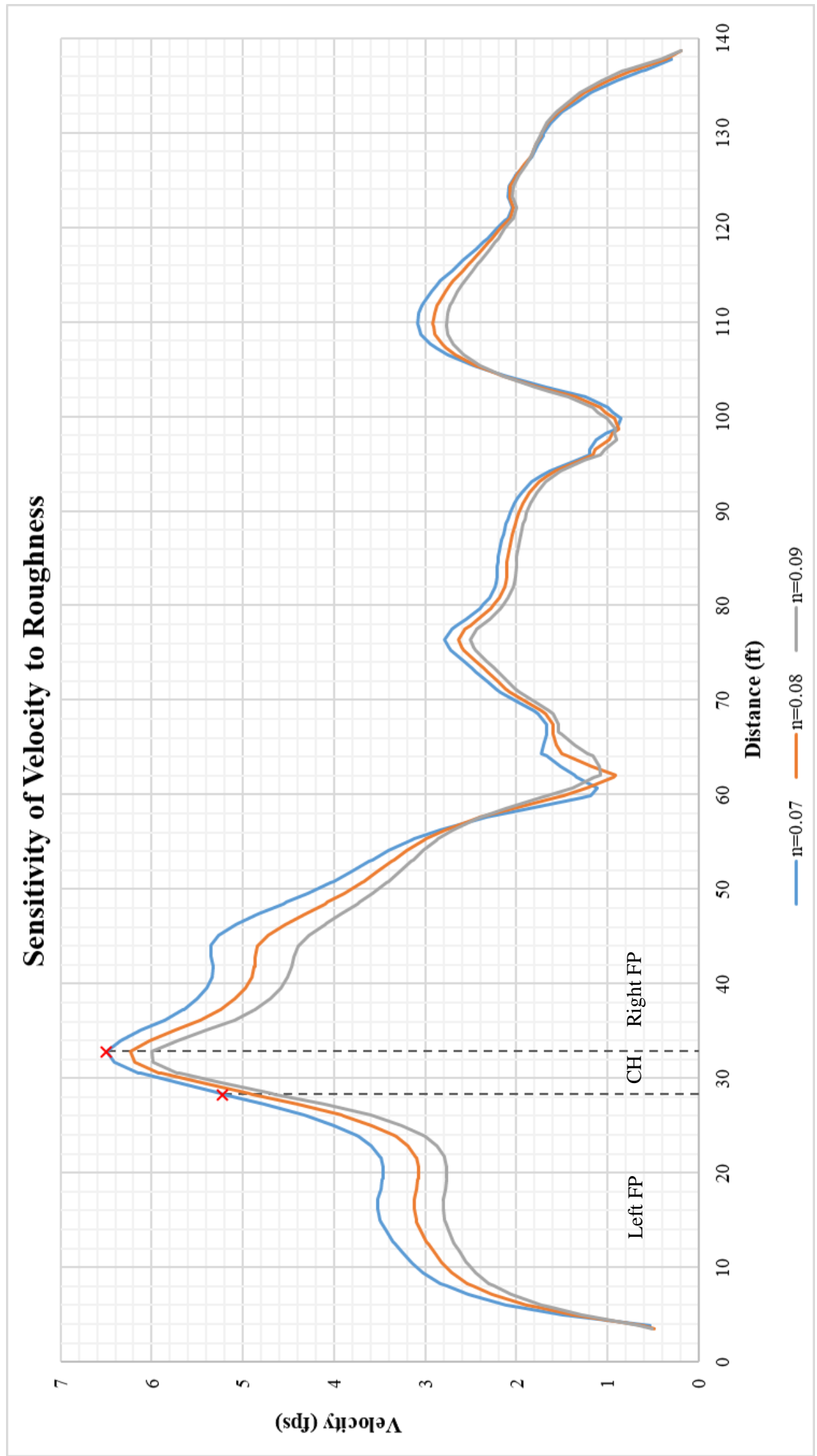

Figure 8. Sensitivity of Velocity to Roughness variation - Slabcamp Creek 
Table 4. Comparison of the average shear stress for different Inflow-Slabcamp Creek

\begin{tabular}{|c|c|c|c|c|c|c|c|}
\hline & & \multicolumn{2}{|c|}{$\begin{array}{c}\text { Left } \\
\text { Floodplain }\end{array}$} & \multicolumn{2}{c|}{ Channel } & \multicolumn{2}{c|}{$\begin{array}{c}\text { Right } \\
\text { Floodplain }\end{array}$} \\
\hline & $\begin{array}{c}\text { Flow } \\
(\mathbf{c f s})\end{array}$ & $\begin{array}{c}\boldsymbol{\tau}_{\text {avg }} \\
(\mathbf{p s f})\end{array}$ & $\begin{array}{c}\text { Percentage } \\
\text { Change* }\end{array}$ & $\begin{array}{c}\boldsymbol{\tau}_{\text {avg }} \\
(\mathbf{p s f})\end{array}$ & $\begin{array}{c}\text { Percentage } \\
\text { Change }^{*}\end{array}$ & $\begin{array}{c}\boldsymbol{\tau}_{\text {avg }} \\
(\mathbf{p s f})\end{array}$ & $\begin{array}{c}\text { Percentage } \\
\text { Change* }^{*}\end{array}$ \\
\hline $\mathbf{5 0} \mathbf{Y r}$ & 331 & 1.23 & $-10.9 \%$ & 1.36 & $-1.18 \%$ & 0.96 & $-20.3 \%$ \\
\hline $\mathbf{1 0 0}-\mathbf{Y r}$ & 385 & 1.36 & & 1.38 & & 1.10 & \\
\hline $\mathbf{2 0 0}-\mathbf{Y r}$ & 441 & 1.54 & $+13.0 \%$ & 1.42 & $+3.16 \%$ & 1.35 & $+17.6 \%$ \\
\hline
\end{tabular}

* These percentage changes are calculated based on 100-year flow.

Table 5. Comparison of the maximum shear stress for different Inflow - Slabcamp Creek

\begin{tabular}{|c|c|c|c|c|c|c|c|}
\hline & & \multicolumn{2}{|c|}{$\begin{array}{c}\text { Left } \\
\text { Floodplain }\end{array}$} & \multicolumn{2}{c|}{ Channel } & \multicolumn{2}{c|}{$\begin{array}{c}\text { Right } \\
\text { Floodplain }\end{array}$} \\
\hline & $\begin{array}{c}\text { Flow } \\
(\mathbf{c f s})\end{array}$ & $\begin{array}{c}\boldsymbol{\tau}_{\max } \\
(\mathbf{p s f})\end{array}$ & $\begin{array}{c}\text { Percentage } \\
\text { Change* }\end{array}$ & $\begin{array}{c}\tau_{\max } \\
(\mathbf{p s f})\end{array}$ & $\begin{array}{c}\text { Percentage } \\
\text { Change }^{*}\end{array}$ & $\begin{array}{c}\tau_{\max } \\
(\mathbf{p s f})\end{array}$ & $\begin{array}{c}\text { Percentage } \\
\text { Change }^{*}\end{array}$ \\
\hline $\mathbf{5 0} \mathbf{Y r}$ & 331 & 2.31 & $-6.6 \%$ & 2.08 & $-5.5 \%$ & 4.16 & $-6.1 \%$ \\
\hline $\mathbf{1 0 0}-\mathbf{Y r}$ & 385 & 2.46 & & 2.19 & & 4.41 & \\
\hline $\mathbf{2 0 0}-\mathbf{Y r}$ & 441 & 2.6 & $+5.8 \%$ & 2.29 & $+4.5 \%$ & 4.63 & $+5.0 \%$ \\
\hline
\end{tabular}

$*$ These percentage changes are calculated based on 100-year flow.

Table 6. Comparison of the average velocity for different Inflow - Slabcamp Creek

\begin{tabular}{|c|c|c|c|c|c|c|c|}
\hline & & \multicolumn{2}{|c|}{$\begin{array}{c}\text { Left } \\
\text { Floodplain }\end{array}$} & \multicolumn{2}{c|}{ Channel } & \multicolumn{2}{c|}{$\begin{array}{c}\text { Right } \\
\text { Floodplain }\end{array}$} \\
\hline & $\begin{array}{c}\text { Flow } \\
\text { (cfs) }\end{array}$ & $\begin{array}{c}\text { V avg } \\
\text { (fps) }\end{array}$ & $\begin{array}{c}\text { Percentage } \\
\text { Change }\end{array}$ & $\begin{array}{c}\mathbf{V}_{\text {avg }} \\
\text { (fps) }\end{array}$ & $\begin{array}{c}\text { Percentage } \\
\text { Change }^{*}\end{array}$ & $\begin{array}{c}\mathbf{V}_{\text {avg }} \\
\text { (fps) }\end{array}$ & $\begin{array}{c}\text { Percentage } \\
\text { Change }^{*}\end{array}$ \\
\hline $\mathbf{5 0 - Y r}$ & 331 & 3.10 & $-7.0 \%$ & 5.81 & $-3.2 \%$ & 2.29 & $-12.4 \%$ \\
\hline $\mathbf{1 0 0}-\mathbf{Y r}$ & 385 & 3.31 & & 6.0 & & 2.60 & \\
\hline $\mathbf{2 0 0}-\mathbf{Y r}$ & 441 & 3.64 & $+10.0 \%$ & 6.21 & $+3.7 \%$ & 2.82 & $+9.3 \%$ \\
\hline
\end{tabular}

$*$ These percentage changes are calculated based on 100-year flow.

Table 7. Comparison of the maximum velocity for different Inflow - Slabcamp Creek

\begin{tabular}{|c|c|c|c|c|c|c|c|}
\hline & & \multicolumn{3}{c|}{$\begin{array}{c}\text { Left } \\
\text { Floodplain }\end{array}$} & \multicolumn{2}{c|}{ Channel } & \multicolumn{3}{c|}{$\begin{array}{c}\text { Right } \\
\text { Floodplain }\end{array}$} \\
\hline & $\begin{array}{c}\text { Flow } \\
\text { (cfs) }\end{array}$ & $\begin{array}{c}\text { V max } \\
\text { (fps) }\end{array}$ & $\begin{array}{c}\text { Percentage } \\
\text { Change* }\end{array}$ & $\begin{array}{c}\text { V max } \\
\text { (fps) }\end{array}$ & $\begin{array}{c}\text { Percentage } \\
\text { Change }^{*}\end{array}$ & $\begin{array}{c}\text { V max } \\
\text { (fps) }\end{array}$ & $\begin{array}{c}\text { Percentage } \\
\text { Change }^{*}\end{array}$ \\
\hline $\mathbf{5 0 - Y r}$ & 331 & 4.56 & $-4.2 \%$ & 6.27 & $-3.5 \%$ & 6.10 & $-3.9 \%$ \\
\hline $\mathbf{1 0 0}-\mathbf{Y r}$ & 385 & 4.77 & & 6.49 & & 6.34 & \\
\hline $\mathbf{2 0 0}-\mathbf{Y r}$ & 441 & 4.94 & $+3.7 \%$ & 6.68 & $+3.0 \%$ & 6.55 & $+3.4 \%$ \\
\hline
\end{tabular}

* These percentage changes are calculated based on 100-year flow.

Table 8. Comparison of the average shear stress for different roughness - Slabcamp Creek

\begin{tabular}{|l|c|c|c|c|c|c|c|}
\hline & & \multicolumn{2}{|c|}{$\begin{array}{c}\text { Left } \\
\text { Floodplain }\end{array}$} & \multicolumn{2}{c|}{ Channel } & \multicolumn{3}{c|}{$\begin{array}{c}\text { Right } \\
\text { Floodplain }\end{array}$} \\
\hline & $\begin{array}{c}\text { Flow } \\
(\mathbf{c f s})\end{array}$ & $\begin{array}{c}\boldsymbol{\tau}_{\text {avg }} \\
(\mathbf{p s f})\end{array}$ & $\begin{array}{c}\text { Percentage } \\
\text { Change* }\end{array}$ & $\begin{array}{c}\boldsymbol{\tau}_{\text {avg }} \\
(\mathbf{f p s})\end{array}$ & $\begin{array}{c}\text { Percentage } \\
\text { Change }^{*}\end{array}$ & $\begin{array}{c}\boldsymbol{\tau}_{\text {avg }} \\
(\mathbf{f p s})\end{array}$ & $\begin{array}{c}\text { Percentage } \\
\text { Change }^{*}\end{array}$ \\
\hline $\boldsymbol{n = 0 . 0 7}$ & 400 & 1.36 & $-1.5 \%$ & 1.38 & $+6.0 \%$ & 1.15 & $-14.7 \%$ \\
\hline $\boldsymbol{n = 0 . 0 8}$ & 400 & 1.38 & & 1.30 & & 1.32 & \\
\hline $\boldsymbol{n}=\mathbf{0 . 0 9}$ & 400 & 1.41 & $+2.2 \%$ & 1.16 & $-10.4 \%$ & 1.50 & $+13.3 \%$ \\
\hline
\end{tabular}

*These percentage changes are calculated based on $n=0.08$ 
Table 9. Comparison of the maximum shear stress for different roughness - Slabcamp Creek

\begin{tabular}{|l|c|c|c|c|c|c|c|}
\hline & & \multicolumn{2}{|c|}{$\begin{array}{c}\text { Left } \\
\text { Floodplain }\end{array}$} & \multicolumn{2}{c|}{ Channel } & \multicolumn{2}{c|}{$\begin{array}{c}\text { Right } \\
\text { Floodplain }\end{array}$} \\
\hline & $\begin{array}{c}\text { Flow } \\
\text { (cfs) }\end{array}$ & $\begin{array}{c}\boldsymbol{\tau} \text { max } \\
(\mathbf{p s f})\end{array}$ & $\begin{array}{c}\text { Percentage } \\
\text { Change* }\end{array}$ & $\begin{array}{c}\tau_{\max } \\
(\mathbf{p s f})\end{array}$ & $\begin{array}{c}\text { Percentage } \\
\text { Change }^{*}\end{array}$ & $\begin{array}{c}\boldsymbol{\tau}_{\max } \\
(\mathbf{p s f})\end{array}$ & $\begin{array}{c}\text { Percentage } \\
\text { Change }^{*}\end{array}$ \\
\hline $\boldsymbol{n = 0 . 0 7}$ & 400 & 2.46 & $-10.0 \%$ & 2.19 & $+3.3 \%$ & 4.41 & $-15.9 \%$ \\
\hline $\boldsymbol{n = 0 . 0 8}$ & 400 & 2.71 & & 2.12 & & 5.11 & \\
\hline $\boldsymbol{n = 0 . 0 9}$ & 400 & 2.94 & $+8.7 \%$ & 2.02 & $-4.6 \%$ & 5.76 & $+12.6 \%$ \\
\hline
\end{tabular}

\begin{tabular}{|c|c|c|c|c|c|c|c|}
\hline & \multirow[b]{2}{*}{$\begin{array}{l}\text { Flow } \\
\text { (cfs) }\end{array}$} & \multicolumn{2}{|c|}{$\begin{array}{c}\text { Left } \\
\text { Floodplain }\end{array}$} & \multicolumn{2}{|c|}{ Channel } & \multicolumn{2}{|c|}{$\begin{array}{c}\text { Right } \\
\text { Floodplain }\end{array}$} \\
\hline & & $\begin{array}{l}\text { avg } \\
\text { (fps) }\end{array}$ & $\begin{array}{c}\text { Percentage } \\
\text { Change }^{*}\end{array}$ & $\begin{array}{l}V_{\text {avg }} \\
\text { (fps) }\end{array}$ & $\begin{array}{c}\text { Percentage } \\
\text { Change }^{*}\end{array}$ & $\begin{array}{l}\text { avg } \\
\text { (fps) }\end{array}$ & $\begin{array}{c}\text { Percentage } \\
\text { Change }^{*}\end{array}$ \\
\hline$n=0.07$ & 400 & 3.31 & $+11.3 \%$ & 6.01 & $+2.9 \%$ & 2.58 & $+5.8 \%$ \\
\hline$n=0.08$ & 400 & 2.94 & & 5.82 & & 2.43 & \\
\hline$n=0.09$ & 400 & 2.67 & $-9.2 \%$ & 5.62 & $-3.6 \%$ & 2.32 & $-4.6 \%$ \\
\hline
\end{tabular}

Table 11. Comparison of the maximum velocity for different roughness - Slabcamp Creek

\begin{tabular}{|l|c|c|c|c|c|c|c|}
\hline & & \multicolumn{3}{|c|}{$\begin{array}{c}\text { Left } \\
\text { Floodplain }\end{array}$} & \multicolumn{2}{c|}{ Channel } & \multicolumn{3}{c|}{$\begin{array}{c}\text { Right } \\
\text { Floodplain }\end{array}$} \\
\hline & $\begin{array}{c}\text { Flow } \\
\text { (cfs) }\end{array}$ & $\begin{array}{c}\text { V max } \\
\text { (fps) }\end{array}$ & $\begin{array}{c}\text { Percentage } \\
\text { Change }\end{array}$ & $\begin{array}{c}\text { V max } \\
\text { (fps) }\end{array}$ & $\begin{array}{c}\text { Percentage } \\
\text { Change* }\end{array}$ & $\begin{array}{c}\text { V max } \\
\text { (fps) }\end{array}$ & $\begin{array}{c}\text { Percentage } \\
\text { Change }^{*}\end{array}$ \\
\hline $\boldsymbol{n = 0 . 0 7}$ & 400 & 4.77 & $+7.6 \%$ & 6.49 & $+3.9 \%$ & 6.34 & $+5.0 \%$ \\
\hline $\boldsymbol{n = 0 . 0 8}$ & 400 & 4.40 & & 6.24 & & 6.02 & \\
\hline $\boldsymbol{n = 0 . 0 9}$ & 400 & 4.11 & \multicolumn{6}{|c|}{$-6.7 \%$} & 6.00 & $-3.8 \%$ & 5.80 & $-5.0 \%$ \\
\hline
\end{tabular}

\subsubsection{Brushy Creek}

For comparing the results of the sensitivity analysis for shear stress and velocity, the descriptive statistics are prepared for different parts of the creek such as right floodplain, channel and left floodplain (Figure 9 to Figure 12 and Table 12 to

Table 19).

The sensitivity analysis results revealed that shear stress at the left part of the creek was shown more sensitive to the variations of inflow magnitude compare to the right part of the creek. By comparing shear stress for different inflows at the channel, it can be 
understood that there are almost no changes between them but around the center of the channel it can be seen that the trend of decreasing the shear stress by increasing the inflow has been changed. Similar behavior as seen in Slabcamp is also observed in the left and right of the floodplain near the channel and the maximum of shear stress has happened at the banks (Figure 9). Also, the results of sensitivity display that shear stress is more sensitive to the changes of roughness at distance $30 \mathrm{ft}$ to $40 \mathrm{ft}$ (left floodplain) compare to the other parts of the floodplain. Since the maximum of shear stress has occurred at this distance; so, there is a big difference between those points (Figure 11). Comparing the changes of average value of shear stress for different inflows shows the same thing happened in the left, channel and right part of the floodplain (Table 12).

It can be seen that, there is almost constant variation for velocity with increasing the discharge in the right and left part of the floodplain; however, the behavior of velocity in the channel is not predictable (Figure 10), but the average value of velocity for the channel for 100-yr flow is 0.08 fps more than the 50 -yr flow and 0.09 fps less than $200-y r$ flow and there is a rise between them (

Table 13). Moreover, the changes of velocity with enhancing the roughness is very consistent except the first part of the left floodplain and the end part of the right floodplain which the trend has been reversed (Figure 12). However, this behavior does not affect the average number of velocity and in both sides of the creek with increasing the roughness, the average velocity has been decreased and the difference for both sides between each roughness is very close. The average velocity for roughness 0.07 is $0.512 \mathrm{fps}$ more than the roughness 0.08 and the roughness 0.09 is $0.51 \mathrm{fps}$ less than the roughness 0.08 for the left side and those numbers for the right side is $0.156 \mathrm{fps}$ and $0.134 \mathrm{fps}$, respectively ( 
Table 18).

Increasing inflow magnitude increases the average and peak values of shear stress magnitude in the floodplains but slightly decreased the average and peak values in the channel (Figure 9, Table 12 and Table 13). The variation of approximately $26 \%$ in flow (13\% less than the 100 year flow for the 50 -yr flow to $13 \%$ higher than the 100 year flow for the 200 yr event) caused a total decrease in channel average stress by approximately $0.2 \%$ and increases in floodplain average stress by $12.9 \%$ and $19.7 \%$ in the left and right floodplains, respectively. The variation in maximum shear stress for the same variation in flow is $-2.3 \%, 1.6 \%$ and $17.8 \%$ for the channel, left floodplain and right floodplain, respectively.

Likewise, increasing inflow magnitude increases the average and peak values of velocity magnitude in the channel and floodplains (Figure 10, Table 14 and Table 15). The variation of approximately $26 \%$ in flow caused a total increase in channel average velocity by approximately $2.5 \%$ and increases in floodplain average velocity by $9.2 \%$ and $10.9 \%$ in the left and right floodplains, respectively. The variation in maximum velocity for the same variation in flow is $0.9 \%, 1.6 \%$ and $11.0 \%$ for the channel, left floodplain and right floodplain, respectively.

As anticipated, increasing floodplain roughness increased the average and peak values of shear stress magnitude in the floodplains (Figure 11, Table 16 and Table 17). The variation of approximately $25 \%$ in Manning n (0.07 to 0.09) resulted in a total increase in floodplain average stress of $12.8 \%$ and $22.1 \%$ in the left and right floodplains, respectively. The channel stress, however, decreased by $22.6 \%$. As in the Slabcamp Creek model, this decrease in channel stress with increased floodplain roughness was a surprise. The 
variation in maximum shear stress for the same variation in $\mathrm{n}$ values was $-14.9 \%, 33.4 \%$ and $15.2 \%$ for the channel, left floodplain and right floodplain, respectively. The maximum channel shear decreased with increased floodplain shear stress similar to the average channel shear stress.

Increasing Manning $\mathrm{n}$ decreased the average and peak values of velocity magnitude in the channel and floodplains (Figure 12, Table 18 and Table 19). The variation of approximately $25 \%$ in Manning n (0.07 to 0.09$)$ resulted in a total decrease in average velocity by $11.2 \%, 17.0 \%, 11.9 \%$, for channel, left floodplain, and right floodplains, respectively. The maximum velocity for the same variation in roughness decreased by $6.8 \%, 7.2 \%$ and $15.5 \%$ for the channel, left floodplain and right floodplain, respectively. Similar to the Slabcamp model, the maximum velocity in the channel decreased with increased roughness of the floodplains even though the channel roughness was not changed. 


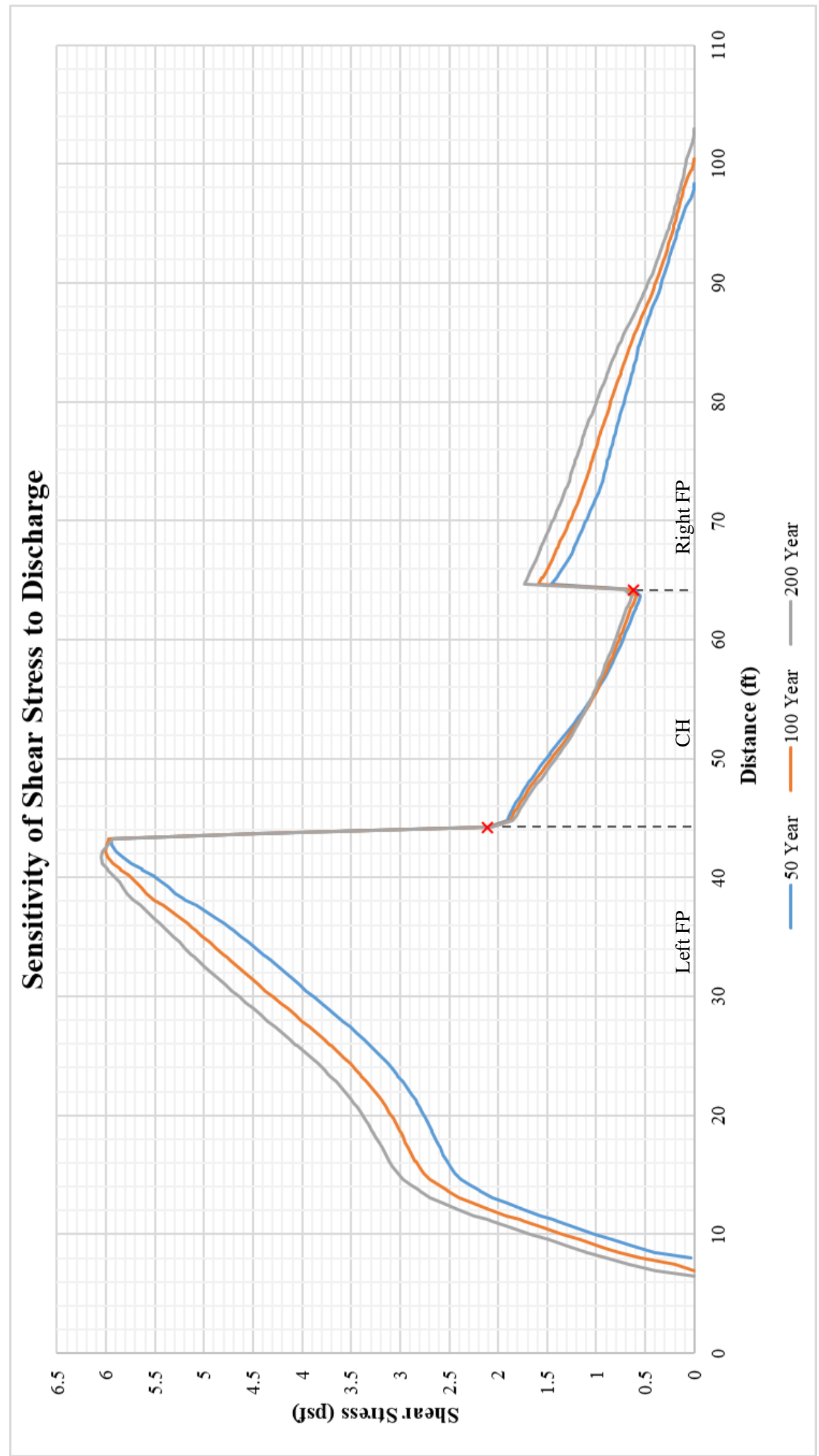

Figure 9. Sensitivity of Shear Stress to Discharge variation - Brushy Creek 


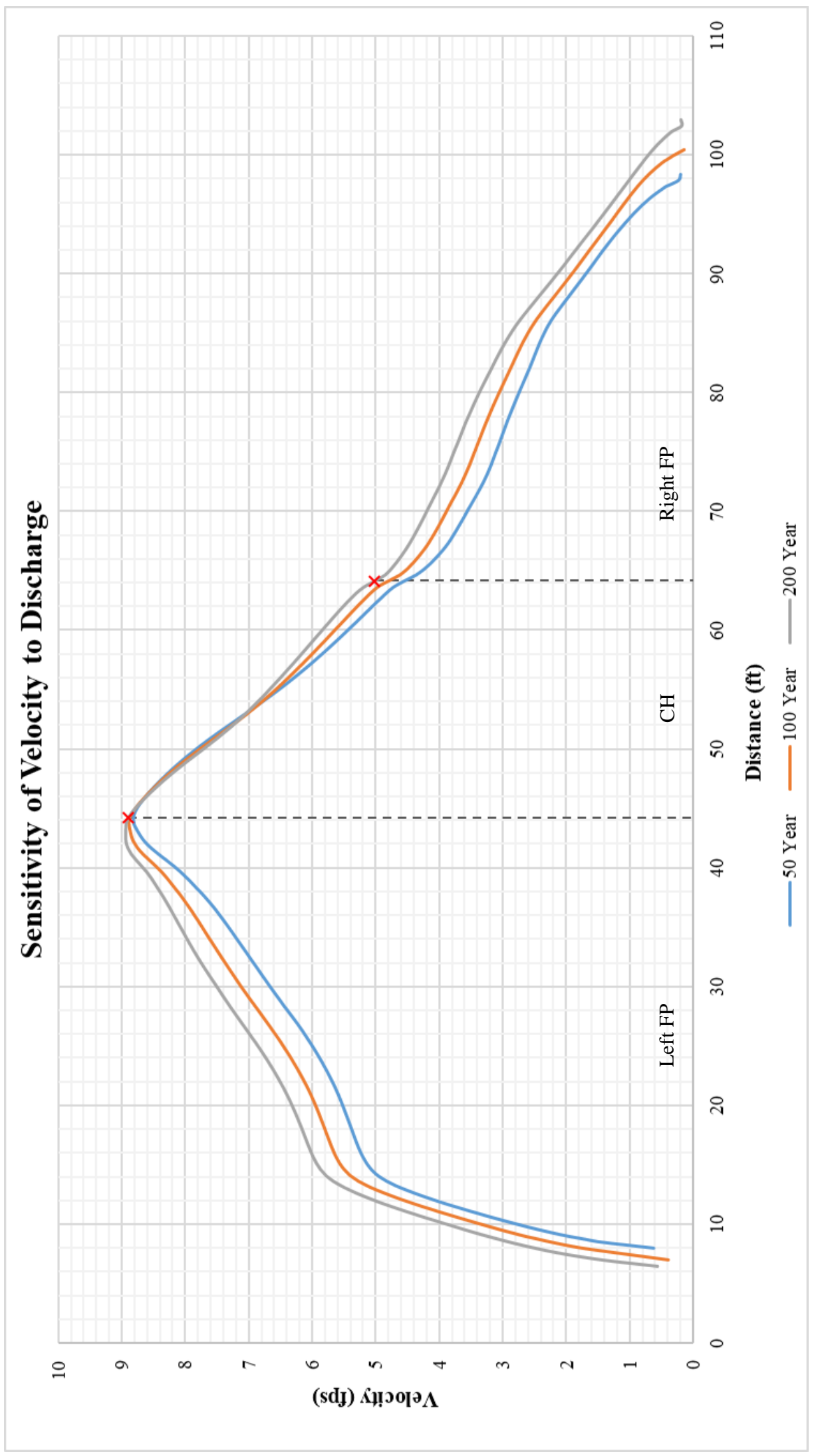

Figure 10. Sensitivity of Velocity to Discharge variation - Brushy Creek 


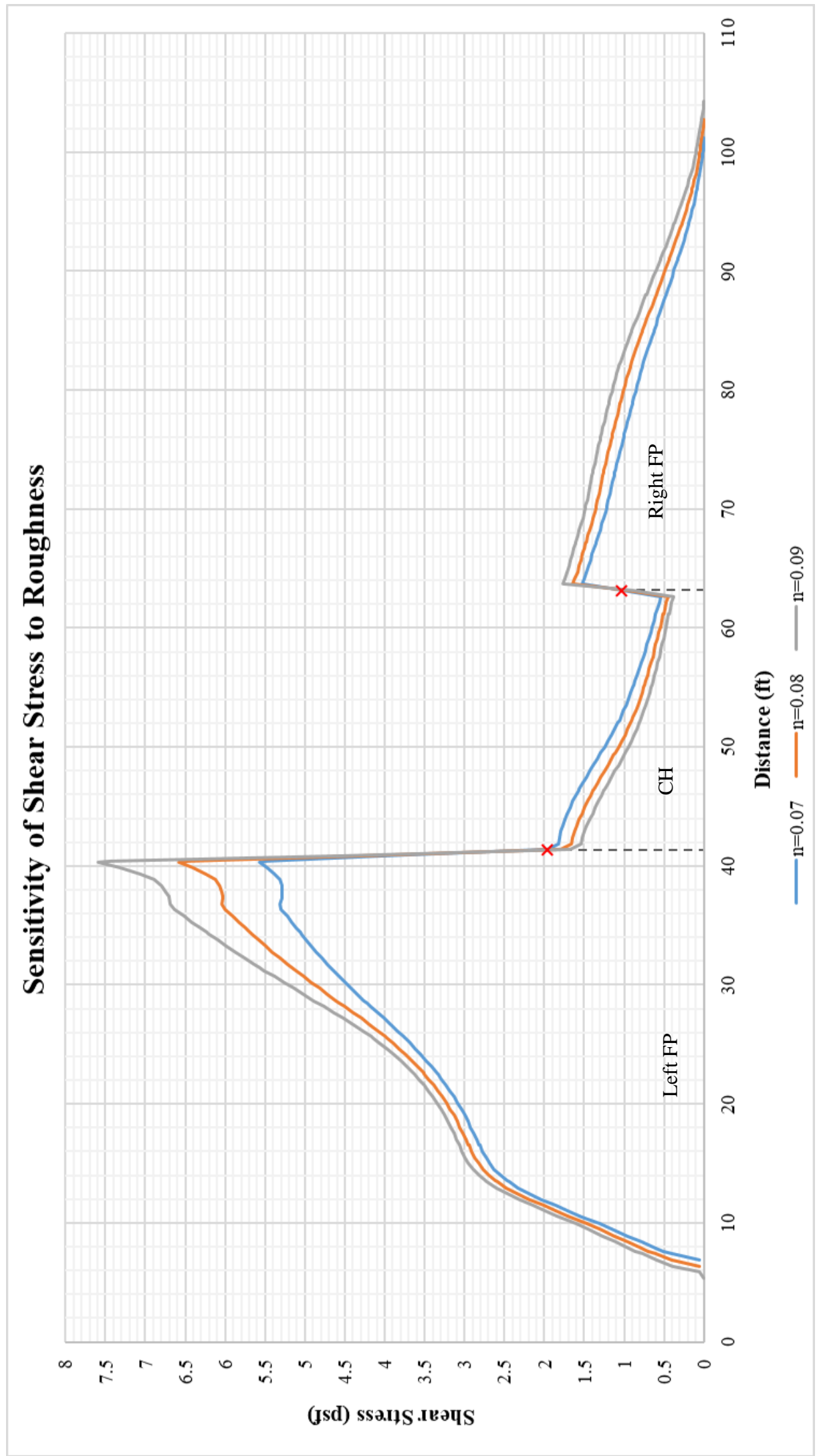

Figure 11. Sensitivity of Velocity to Discharge variation - Brushy Creek 


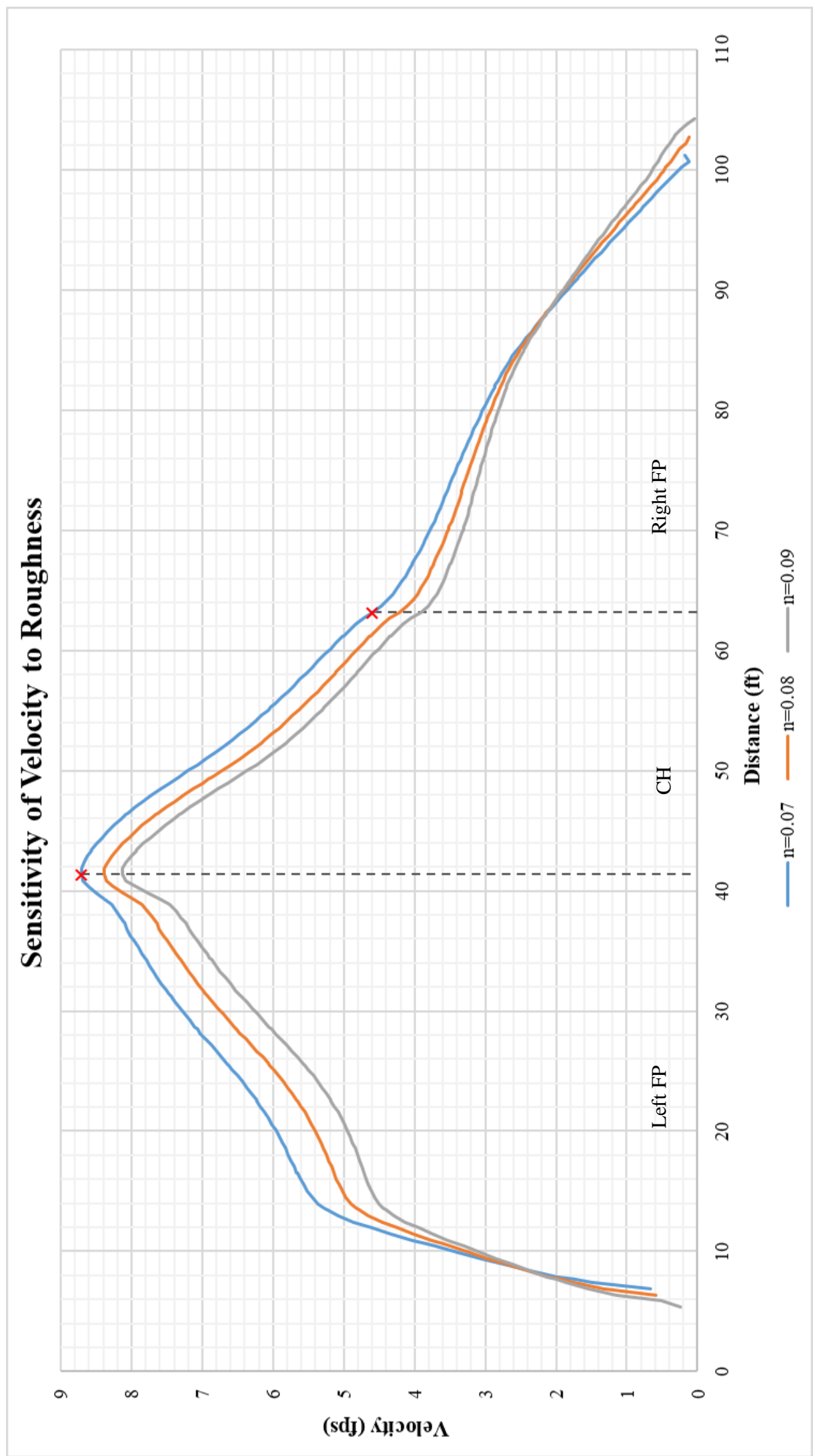

Figure 12. Sensitivity of Velocity to Roughness variation - Brushy Creek 
Table 12. Comparison of the average shear stress for different Inflow - Brushy Creek

\begin{tabular}{|c|c|c|c|c|c|c|c|}
\hline & & \multicolumn{2}{|c|}{$\begin{array}{c}\text { Left } \\
\text { Floodplain }\end{array}$} & \multicolumn{2}{c|}{ Channel } & \multicolumn{2}{c|}{$\begin{array}{c}\text { Right } \\
\text { Floodplain }\end{array}$} \\
\hline & $\begin{array}{c}\text { Flow } \\
(\mathbf{c f s})\end{array}$ & $\begin{array}{c}\boldsymbol{\tau}_{\text {avg }} \\
(\mathbf{p s f})\end{array}$ & $\begin{array}{c}\text { Percentage } \\
\text { Change* }^{*}\end{array}$ & $\begin{array}{c}\boldsymbol{\tau}_{\text {avg }} \\
(\mathbf{p s f})\end{array}$ & $\begin{array}{c}\text { Percentage } \\
\text { Change }^{*}\end{array}$ & $\begin{array}{c}\boldsymbol{\tau}_{\text {avg }} \\
(\mathbf{p s f})\end{array}$ & $\begin{array}{c}\text { Percentage } \\
\text { Change* }^{*}\end{array}$ \\
\hline $\mathbf{5 0} \mathbf{Y r}$ & 2090 & 3.46 & $-6.8 \%$ & 1.21 & $+0.4 \%$ & 0.66 & $-11.1 \%$ \\
\hline $\mathbf{1 0 0}-\mathbf{Y r}$ & 2400 & 3.69 & & 1.20 & & 0.73 & \\
\hline $\mathbf{2 0 0}-\mathbf{Y r}$ & 2710 & 3.92 & $+6.1 \%$ & 1.20 & $+0.2 \%$ & 0.79 & $+8.7 \%$ \\
\hline
\end{tabular}

* These percentage changes are calculated based on 100-year flow.

\begin{tabular}{|c|c|c|c|c|c|c|c|}
\hline & & \multicolumn{2}{|c|}{$\begin{array}{c}\text { Left } \\
\text { Floodplain }\end{array}$} & \multicolumn{2}{|c|}{ Channel } & \multicolumn{2}{|c|}{$\begin{array}{c}\text { Right } \\
\text { Floodplain }\end{array}$} \\
\hline & $\begin{array}{c}\text { Flow } \\
\text { (cfs) }\end{array}$ & $\begin{array}{l}\tau_{\max } \\
(\mathbf{p s f})\end{array}$ & $\begin{array}{c}\text { Percentage } \\
\text { Change }^{*}\end{array}$ & $\begin{array}{l}\tau \text { max } \\
(\mathbf{p s f})\end{array}$ & $\begin{array}{c}\text { Percentage } \\
\text { Change }^{*}\end{array}$ & $\begin{array}{l}\tau \text { max } \\
(\text { psf) }\end{array}$ & $\begin{array}{c}\text { Percentage } \\
\text { Change }^{*}\end{array}$ \\
\hline $50-Y r$ & 2090 & 5.96 & $-0.9 \%$ & 2.11 & $+0.9 \%$ & 1.46 & $-9.2 \%$ \\
\hline 100-Yr & 2400 & 6.01 & & 2.09 & & 1.60 & \\
\hline $200-Y r$ & 2710 & 6.05 & $+0.7 \%$ & 2.06 & $-1.4 \%$ & 1.73 & $+8.6 \%$ \\
\hline
\end{tabular}

$*$ These percentage changes are calculated based on 100-year flow.

Table 14. Comparison of the average velocity for different Inflow-Brushy Creek

\begin{tabular}{|c|c|c|c|c|c|c|c|}
\hline & & \multicolumn{2}{|c|}{$\begin{array}{c}\text { Left } \\
\text { Floodplain }\end{array}$} & \multicolumn{2}{c|}{ Channel } & \multicolumn{2}{c|}{$\begin{array}{c}\text { Right } \\
\text { Floodplain }\end{array}$} \\
\hline & $\begin{array}{c}\text { Flow } \\
\text { (cfs) }\end{array}$ & $\begin{array}{c}\text { V avg } \\
\text { (fps) }\end{array}$ & $\begin{array}{c}\text { Percentage } \\
\text { Change* }\end{array}$ & $\begin{array}{c}\text { V avg } \\
\text { (fps) }\end{array}$ & $\begin{array}{c}\text { Percentage } \\
\text { Change }^{*}\end{array}$ & $\begin{array}{c}\text { V avg } \\
\text { (fps) }\end{array}$ & $\begin{array}{c}\text { Percentage } \\
\text { Change }^{*}\end{array}$ \\
\hline $\mathbf{5 0}-\mathbf{Y r}$ & 2090 & 6.11 & $-4.6 \%$ & 6.90 & $-1.2 \%$ & 2.44 & $-6.6 \%$ \\
\hline $\mathbf{1 0 0}-\mathbf{Y r}$ & 2400 & 6.40 & & 6.97 & & 2.60 & \\
\hline $\mathbf{2 0 0}-\mathbf{Y r}$ & 2710 & 6.69 & $+4.6 \%$ & 7.06 & $+1.3 \%$ & 2.71 & $+4.4 \%$ \\
\hline
\end{tabular}

* These percentage changes are calculated based on 100-year flow.

Table 15. Comparison of the maximum velocity for different Inflow - Brushy Creek

\begin{tabular}{|c|c|c|c|c|c|c|c|}
\multicolumn{1}{|c|}{} & \multicolumn{2}{|c|}{$\begin{array}{c}\text { Left } \\
\text { Floodplain }\end{array}$} & \multicolumn{2}{c|}{ Channel } & \multicolumn{3}{c|}{$\begin{array}{c}\text { Right } \\
\text { Floodplain }\end{array}$} \\
\hline & $\begin{array}{c}\text { Flow } \\
\text { (cfs) }\end{array}$ & $\begin{array}{c}\text { V max } \\
\text { (fps) }\end{array}$ & $\begin{array}{c}\text { Percentage } \\
\text { Change* }\end{array}$ & $\begin{array}{c}\text { V max } \\
\text { (fps) }\end{array}$ & $\begin{array}{c}\text { Percentage } \\
\text { Change }^{*}\end{array}$ & $\begin{array}{c}\text { V max } \\
\text { (fps) }\end{array}$ & $\begin{array}{c}\text { Percentage } \\
\text { Change }^{*}\end{array}$ \\
\hline $\mathbf{5 0 - Y r}$ & 2090 & 8.81 & $-1.0 \%$ & 8.81 & $-0.7 \%$ & 4.36 & $-5.7 \%$ \\
\hline $\mathbf{1 0 0}-\mathbf{Y r}$ & 2400 & 8.90 & & 8.87 & & 4.61 & \\
\hline $\mathbf{2 0 0}-\mathbf{Y r}$ & 2710 & 8.95 & $+0.6 \%$ & 8.90 & $+0.3 \%$ & 4.85 & $+5.3 \%$ \\
\hline
\end{tabular}

* These percentage changes are calculated based on 100-year flow.

Table 16. Comparison of the average shear stress for different Roughness - Brushy Creek

\begin{tabular}{|c|c|c|c|c|c|c|c|}
\hline & \multirow[b]{2}{*}{$\begin{array}{c}\text { Flow } \\
\text { (cfs) }\end{array}$} & \multicolumn{2}{|c|}{$\begin{array}{c}\text { Left } \\
\text { Floodplain }\end{array}$} & \multicolumn{2}{|c|}{ Channel } & \multicolumn{2}{|c|}{$\begin{array}{c}\text { Right } \\
\text { Floodplain }\end{array}$} \\
\hline & & $\begin{array}{r}\tau \text { avg } \\
(\text { psf }) \\
\end{array}$ & $\begin{array}{c}\text { Percentage } \\
\text { Change }^{*}\end{array}$ & $\begin{array}{l}\tau \text { avg } \\
(\mathbf{p s f}) \\
\end{array}$ & $\begin{array}{c}\text { Percentage } \\
\text { Change }^{*}\end{array}$ & $\begin{array}{l}\tau \text { avg } \\
(\mathbf{p s f})\end{array}$ & $\begin{array}{c}\text { Percentage } \\
\text { Change }^{*}\end{array}$ \\
\hline$n=0.07$ & 2400 & 3.51 & $-8.0 \%$ & 1.17 & $+12.4 \%$ & 0.71 & $-11.9 \%$ \\
\hline$n=0.08$ & 2400 & 3.79 & & 1.03 & & 0.79 & \\
\hline$n=0.09$ & 2400 & 3.97 & $+4.7 \%$ & 0.92 & $-10.2 \%$ & 0.88 & $+10.2 \%$ \\
\hline
\end{tabular}

* These percentage changes are calculated based on $n=0.08$. 
Table 17. Comparison of the maximum shear stress for different Roughness - Brushy Creek

\begin{tabular}{|l|c|c|c|c|c|c|c|}
\hline & & \multicolumn{2}{|c|}{$\begin{array}{c}\text { Left } \\
\text { Floodplain }\end{array}$} & \multicolumn{2}{c|}{ Channel } & \multicolumn{2}{c|}{$\begin{array}{c}\text { Right } \\
\text { Floodplain }\end{array}$} \\
\hline & $\begin{array}{c}\text { Flow } \\
(\mathbf{c f s})\end{array}$ & $\begin{array}{c}\boldsymbol{\tau} \text { max } \\
(\mathbf{p s f})\end{array}$ & $\begin{array}{c}\text { Percentage } \\
\text { Change }^{*}\end{array}$ & $\begin{array}{c}\boldsymbol{\tau}_{\max } \\
(\mathbf{p s f})\end{array}$ & $\begin{array}{c}\text { Percentage } \\
\text { Change }^{*}\end{array}$ & $\begin{array}{c}\boldsymbol{\tau}_{\text {max }} \\
(\mathbf{p s f})\end{array}$ & $\begin{array}{c}\text { Percentage } \\
\text { Change }^{*}\end{array}$ \\
\hline $\boldsymbol{n = 0 . 0 7}$ & 2400 & 5.57 & $-18.1 \%$ & 1.96 & $+7.8 \%$ & 1.52 & $-7.9 \%$ \\
\hline $\boldsymbol{n = 0 . 0 8}$ & 2400 & 6.58 & & 1.80 & & 1.64 & \\
\hline $\boldsymbol{n = 0 . 0 9}$ & 2400 & 7.60 & $+15.4 \%$ & 1.68 & $-7.1 \%$ & 1.76 & $+7.2 \%$ \\
\hline
\end{tabular}

* These percentage changes are calculated based on $\mathrm{n}=0.08$.

\begin{tabular}{|} 
Table 18. Comparison of the average velocity for different Roughness-Brushy Creek \\
\begin{tabular}{|c|c|c|c|c|c|c|c|}
\hline \multirow{2}{*}{} & & \multicolumn{2}{|c|}{$\begin{array}{c}\text { Left } \\
\text { Flodplain }\end{array}$} & \multicolumn{2}{c|}{ Channel } & \multicolumn{3}{c|}{$\begin{array}{c}\text { Right } \\
\text { Floodplain }\end{array}$} \\
\hline & $\begin{array}{c}\text { Flow } \\
\text { (cfs) }\end{array}$ & $\begin{array}{c}\mathbf{V}_{\text {avg }} \\
\text { (fps) }\end{array}$ & $\begin{array}{c}\text { Percentage } \\
\text { Change* }\end{array}$ & $\begin{array}{c}\mathbf{V}_{\text {avg }} \\
\text { (fps) }\end{array}$ & $\begin{array}{c}\text { Percentage } \\
\text { Change }^{*}\end{array}$ & $\begin{array}{c}\text { V avg } \\
\text { (fps) }\end{array}$ & $\begin{array}{c}\text { Percentage } \\
\text { Change }^{*}\end{array}$ \\
\hline $\boldsymbol{n = 0 . 0 7}$ & 2400 & 6.26 & $+8.2 \%$ & 6.85 & $+6.2 \%$ & 2.52 & $+6.2 \%$ \\
\hline $\boldsymbol{n = 0 . 0 8}$ & 2400 & 5.75 & & 6.42 & & 2.37 & \\
\hline $\boldsymbol{n = 0 . 0 9}$ & 2400 & 5.24 & $-8.9 \%$ & 6.10 & $-5.1 \%$ & 2.23 & $-5.7 \%$ \\
\hline
\end{tabular}
\end{tabular}

$*$ These percentage changes are calculated based on $\mathrm{n}=0.08$.

Table 19. Comparison of the maximum velocity for different Roughness - Brushy Creek

\begin{tabular}{|l|c|c|c|c|c|c|c|}
\hline & & \multicolumn{3}{c|}{$\begin{array}{c}\text { Left } \\
\text { Floodplain }\end{array}$} & \multicolumn{2}{c|}{ Channel } & \multicolumn{2}{c|}{$\begin{array}{c}\text { Right } \\
\text { Floodplain }\end{array}$} \\
\hline & $\begin{array}{c}\text { Flow } \\
\text { (cfs) }\end{array}$ & $\begin{array}{c}\text { V max } \\
\text { (fps) }\end{array}$ & $\begin{array}{c}\text { Percentage } \\
\text { Change }^{*}\end{array}$ & $\begin{array}{c}\text { V max } \\
\text { (fps) }\end{array}$ & $\begin{array}{c}\text { Percentage } \\
\text { Change }\end{array}$ & $\begin{array}{c}\text { V max } \\
\text { (fps) }\end{array}$ & $\begin{array}{c}\text { Percentage } \\
\text { Change }^{*}\end{array}$ \\
\hline $\boldsymbol{n = 0 . 0 7}$ & 2400 & 8.69 & $+3.8 \%$ & 8.71 & $+3.6 \%$ & 4.48 & $+8.3 \%$ \\
\hline $\boldsymbol{n = 0 . 0 8}$ & 2400 & 8.36 & & 8.39 & & 4.10 & \\
\hline $\boldsymbol{n = 0 . 0 9}$ & 2400 & 8.08 & $-3.4 \%$ & 8.13 & $-3.2 \%$ & 3.81 & $-7.2 \%$ \\
\hline
\end{tabular}

4.3 Model Results

Based on both the sensitivity analysis and calibration results for Slabcamp Creek and the sensitivity analysis for Brushy Creek, one model representing the 100-yr flow for each of the sites was selected to complete the remainder of the analysis. The model selected for Slabcamp Creek used a flow of $400 \mathrm{cfs}$ and Manning $\mathrm{n}$ values of 0.04 and 0.07 for the channel and floodplains, respectively. The model for Brushy Creek used the flow of 2400 cfs and Manning n roughness coefficients of 0.04 and 0.07 , for the channel and floodplain, respectively. Detailed descriptions of the results of those models is provided here. 


\subsubsection{Slabcamp Creek}

Color contour maps of shear stress and velocity (Figure 13 and Figure 14) and a vector plot of the velocity direction (Figure 15) were produced. These maps also include the location of the upstream boundary conditions, the downstream boundary conditions and the domain of the model where detailed analysis was conducted. The flow development region near the upstream boundary and the region effected by the downstream boundary are also shown. Detailed analysis was conducted on the region downstream of the flow development region and upstream of the regions effected by the downstream boundary.

A large portion of the inundated area has boundary shear stress (Figure 13) less than 2 psf. Areas of higher shear stress (2-4 psf) are concentrated along the channel, in areas where the inundation area is narrow, and in a few places in wide floodplain areas. Very high stress (greater than $4 \mathrm{psf}$ ) are limited to patches and ridges within the high shear stress areas. Although high stresses are concentrated along the floodplain and in the banks, the channel bed indicates a stress less than 2 psf over most of its length.

The velocity variation (Figure 14) is a bit more complex but generally shows similar trends with the highest velocities concentrated where the inundated area is narrow and along the channel. One exception is the areas of the streambed, where some of the highest velocities occur. In many locations the flow velocity above the channel bed is high and the computed shear stress on the channel bed is low. This is related to the rapid variation in roughness from the channel $(n=0.04)$ to banks and floodplains $(n=0.07)$.

The local vector direction of velocity (Figure 15) is aligned with the channel in inundated areas that are narrow and show high velocities. In many of the wide floodplain 
reaches, areas of cross valley flow are present: some velocity vectors indicate flow at approximately 90 degrees to the down valley direction. The vectors also indicate areas where flow is directed from the channel into stream banks. Where channel velocities are high the impact of flow directed at the banks would increase the potential for bank erosion at velocities that may not cause erosion if aligned with the bank. Diversion of flow from the channel, however, may reduce the stress on banks downstream; the magnitude and direction of the near-bank flow are factoring that effect erosion. 


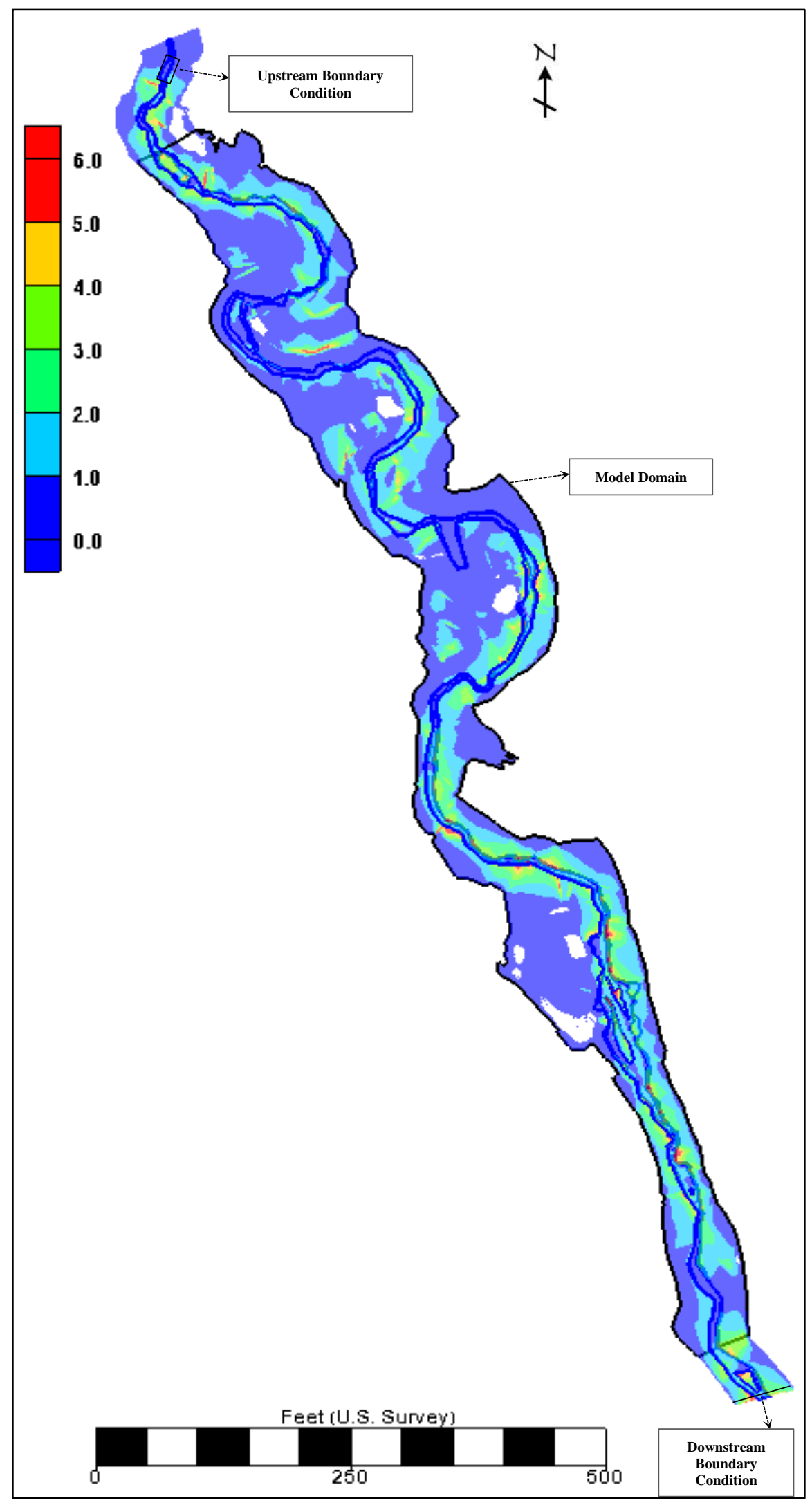

Figure 13. Slabcamp Creek - Shear Stress Distribution 


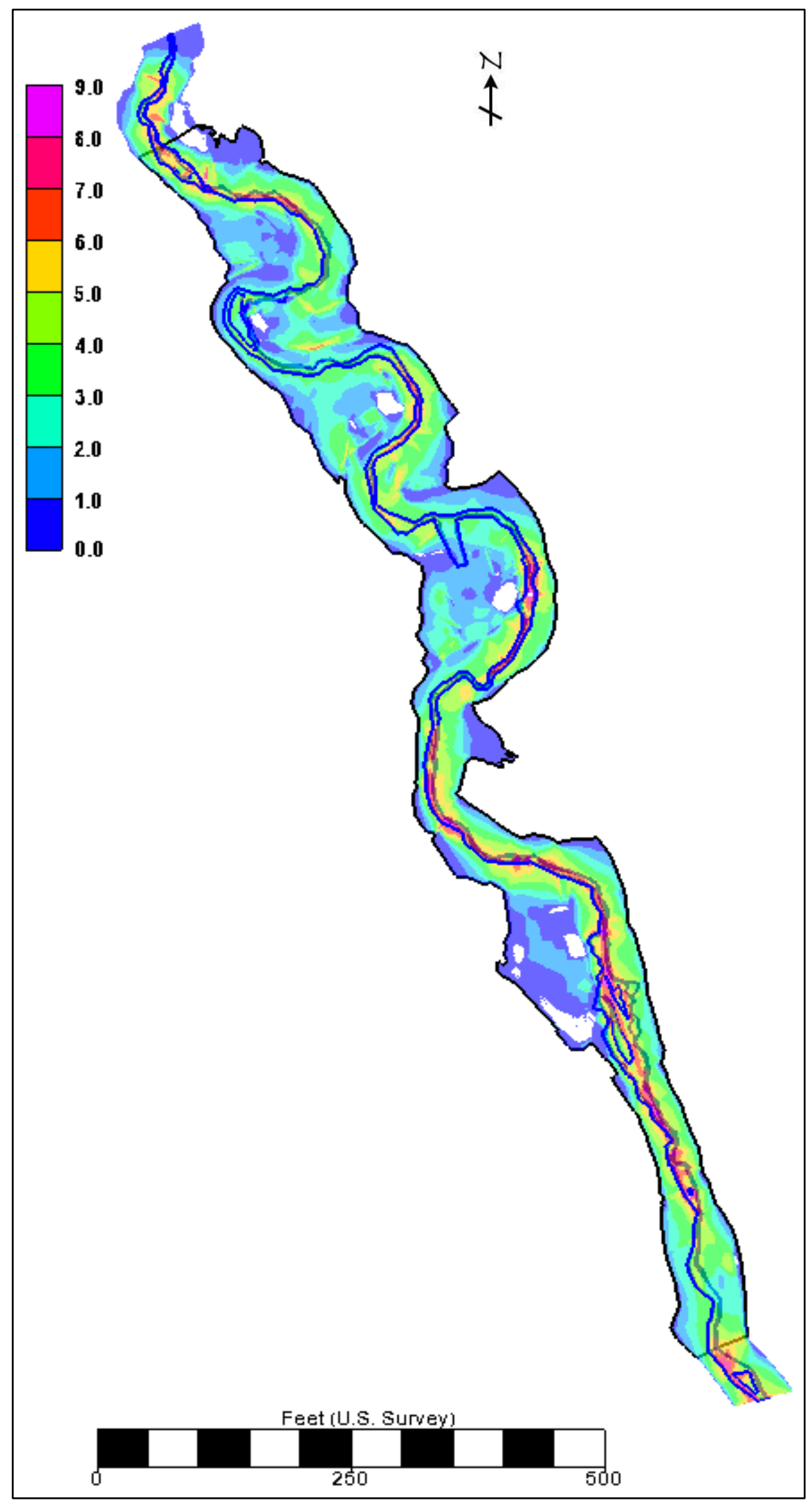

Figure 14. Slabcamp Creek - Velocity Distribution 


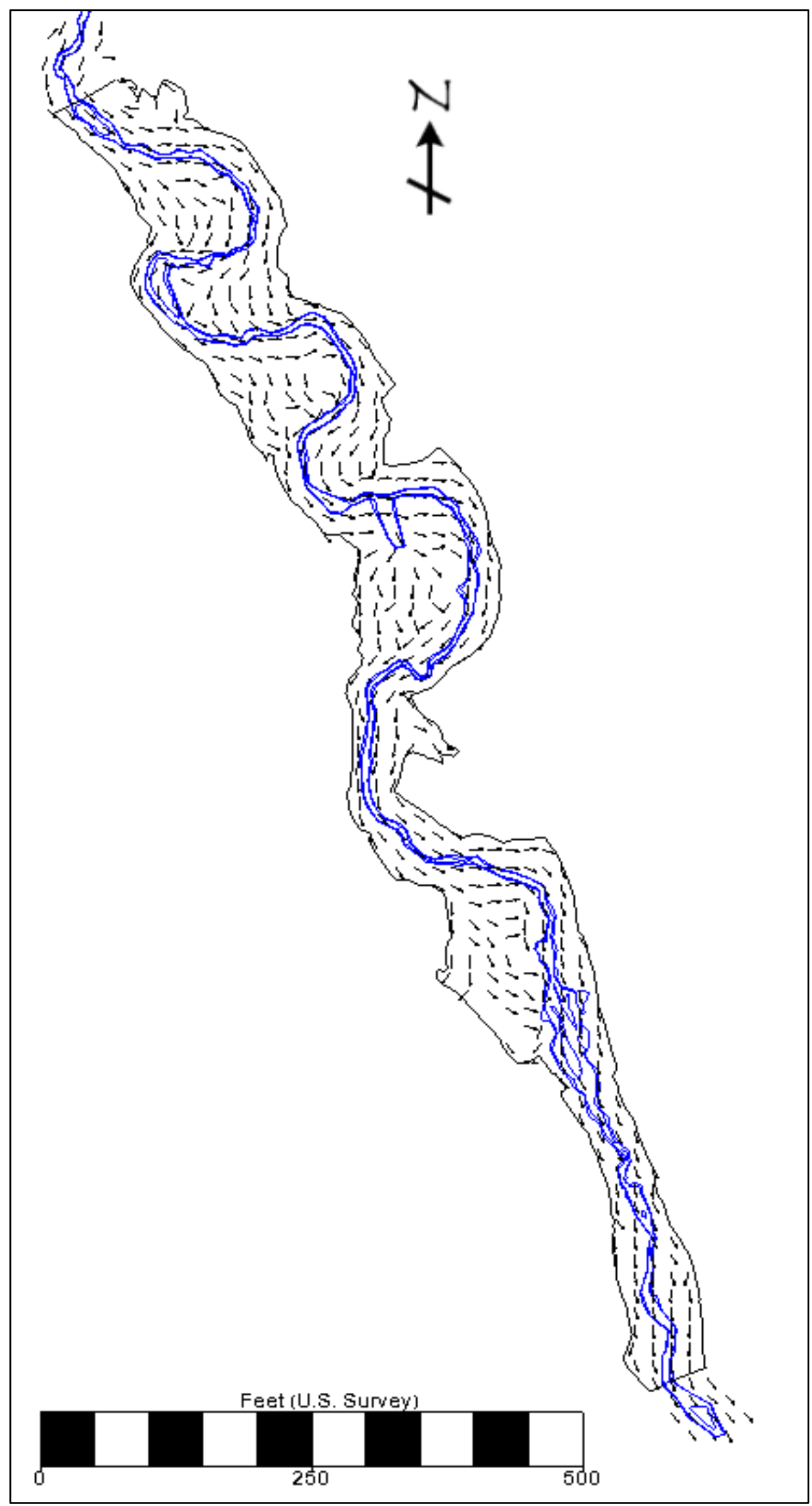

Figure 15. Slabcamp Creek - Velocity Vector 


\subsubsection{Aggregate Statistical Characteristics of Model Velocity Distribution}

The result of a general statistical description of the modeled velocity distributions over the floodplain, banks and channel are provided (Table 20 to Table 25 and Figure 16 to Figure 19). In the tables the frequency of computational nodes and the percent of area in velocity intervals of $1 \mathrm{fps}$ were computed from the model results separately for floodplain areas, channel areas, and channel bank area. More than half of the wetted area on the floodplain (61\%) has a velocity of less than $3 \mathrm{fps}$; about $80 \%$ of floodplain has the velocity less than 4 fps. Although the maximum velocity in the floodplain is $9.40 \mathrm{fps}$, only 10 nodes have a velocity of more than 9 fps.

At the banks, the velocity is higher than the floodplain and almost half of the wetted area on the banks has the velocity less than $4 \mathrm{fps}$ and in about $80 \%$ of its area, the velocity is less than $5 \mathrm{fps}$. It is interesting that based on the numerical results from the model there is just one node with velocity more than $9 \mathrm{fps}$, and it is the maximum amount of velocity (9.02 fps).

The channel has the highest velocity. Forty percente of the channel has the velocity less than 5 fps and about $68 \%$ has velocity less than 6 fps. 100 nodes in the channel have the velocity more than 9 fps. The maximum one is about $9.64 \mathrm{fps}$. Furthermore, the mean value in the channel (5.02 fps) is higher than those of the banks (4.68 fps) and floodplain (2.54 fps), respectively.

\section{Floodplain}

Table 20. Numerical results of velocity distribution for floodplain - Slabcamp Creek

\begin{tabular}{|c|c|c|c|}
\hline Velocity (fps) & Node Frequency* & Area $\left(\boldsymbol{f t}^{2}\right)$ & \% Area \\
\hline $0-1$ & 84886 & 21221.5 & $18.94 \%$ \\
\hline $1-2$ & 95190 & 23797.5 & $21.24 \%$ \\
\hline $2-3$ & 91875 & 22968.75 & $20.50 \%$ \\
\hline $3-4$ & 90617 & 22654.25 & $20.22 \%$ \\
\hline
\end{tabular}




\begin{tabular}{|c|c|c|c|}
\hline $4-5$ & 59059 & 14764.75 & $13.18 \%$ \\
\hline $5-6$ & 21471 & 5367.75 & $4.79 \%$ \\
\hline $6-7$ & 4243 & 1060.75 & $0.95 \%$ \\
\hline $7-8$ & 679 & 169.75 & $0.15 \%$ \\
\hline $8-9$ & 92 & 23 & $0.02 \%$ \\
\hline$>9$ & 10 & 2.5 & $0.00 \%$ \\
\hline
\end{tabular}

*Velocity is calculated at each computational node and represents an area of 0.25 square feet.

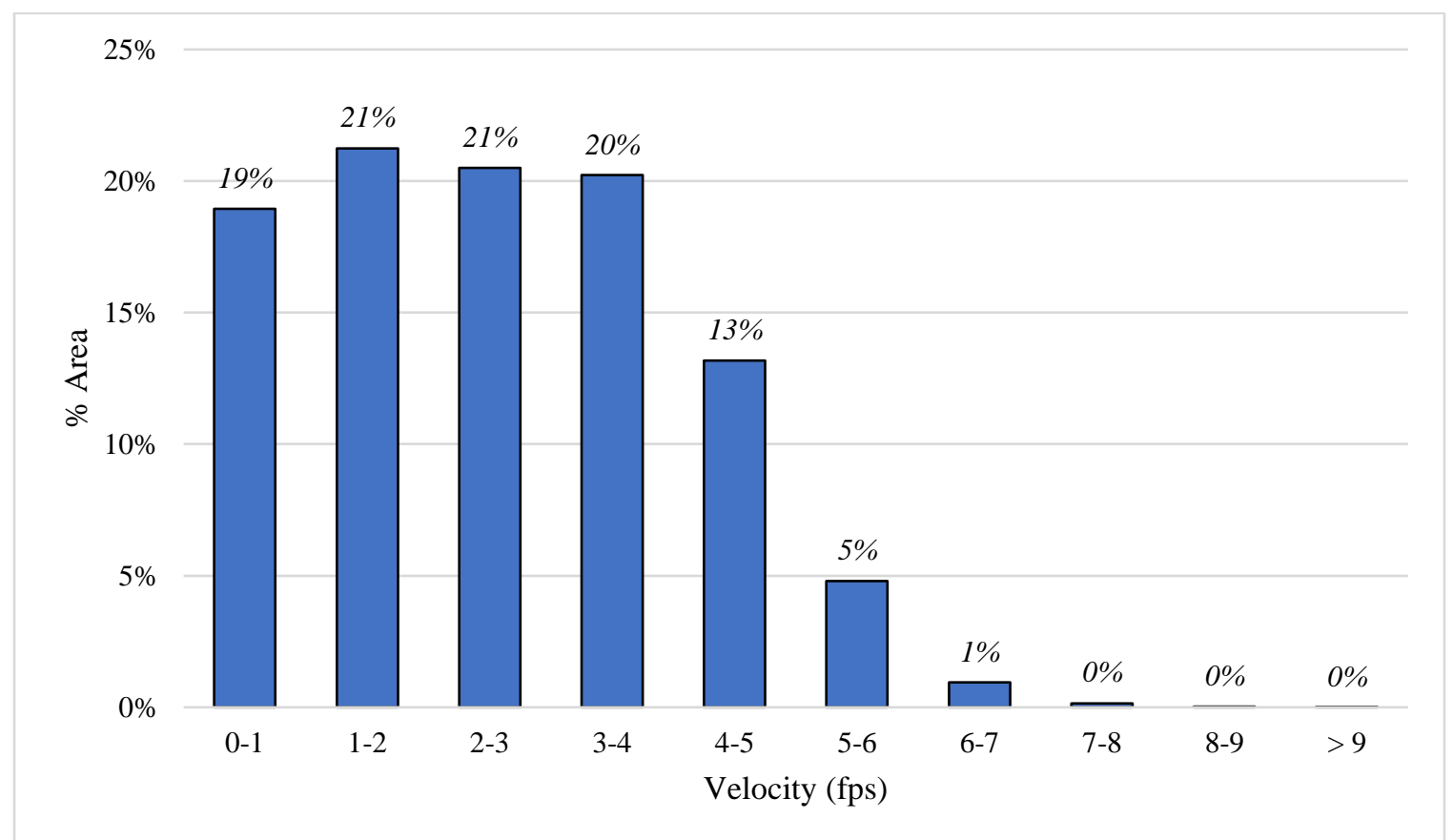

Figure 16. The percentage of area for different velocity categories for floodplain - Slabcamp Creek

Table 21. Descriptive statistics of velocity for floodplain - Slabcamp Creek

\begin{tabular}{|c|c|}
\hline \multicolumn{2}{|c|}{ Velocity $(\boldsymbol{f p s})$} \\
\hline Mean & 2.54 \\
\hline Median & 2.46 \\
\hline Standard Deviation & 1.54 \\
\hline Max & 9.40 \\
\hline Min & 0 \\
\hline
\end{tabular}

Banks

Table 22. Numerical results of velocity distribution for banks - Slabcamp Creek

\begin{tabular}{|c|c|c|c|}
\hline Velocity (fps) & Node Frequency & Area $\left(\boldsymbol{f t}^{2}\right)$ & \% Area \\
\hline $0-1$ & 390 & 97.5 & $1.99 \%$ \\
\hline $1-2$ & 576 & 144 & $2.93 \%$ \\
\hline $2-3$ & 1482 & 370.5 & $7.54 \%$ \\
\hline $3-4$ & 3607 & 901.75 & $18.36 \%$ \\
\hline $4-5$ & 4757 & 1189.25 & $24.22 \%$ \\
\hline
\end{tabular}




\begin{tabular}{|c|c|c|c|}
\hline $5-6$ & 5095 & 1273.75 & $25.94 \%$ \\
\hline $6-7$ & 3045 & 761.25 & $15.50 \%$ \\
\hline $7-8$ & 604 & 151 & $3.07 \%$ \\
\hline $8-9$ & 86 & 21.5 & $0.44 \%$ \\
\hline$>9$ & 1 & 0.25 & $0.01 \%$ \\
\hline
\end{tabular}

*Velocity is calculated at each computational node and represents an area of 0.25 square feet.

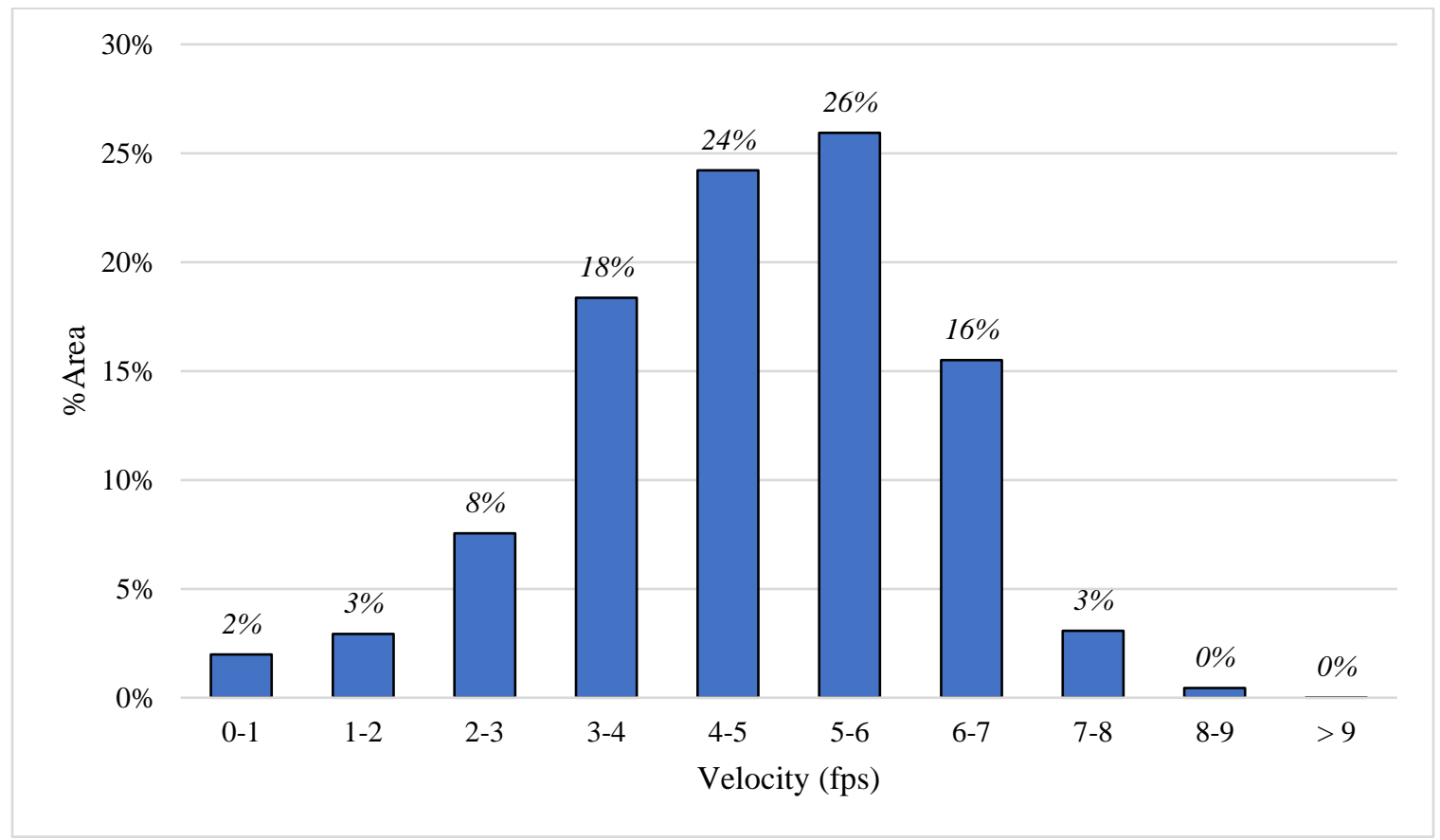

Figure 17. The percentage of area for different velocity categories for banks - Slabcamp Creek

Table 23. Descriptive statistics of velocity for banks - Slabcamp Creek

\begin{tabular}{|c|c|}
\hline \multicolumn{2}{|c|}{ Velocity $(\boldsymbol{f p s})$} \\
\hline Mean & 4.68 \\
\hline Median & 4.83 \\
\hline Standard Deviation & 1.49 \\
\hline Max & 9.02 \\
\hline Min & 0 \\
\hline
\end{tabular}

\section{Channel}

Table 24. Numerical results of velocity distribution for channel-Slabcamp Creek
\begin{tabular}{|c|c|c|c|}
\hline Velocity (fps) & Node Frequency & Area $\left(\boldsymbol{f t}^{2}\right)$ & \% Area \\
\hline $0-1$ & 450 & 112.5 & $0.91 \%$ \\
\hline $1-2$ & 1455 & 363.75 & $2.95 \%$ \\
\hline $2-3$ & 3828 & 957 & $7.76 \%$ \\
\hline $3-4$ & 7701 & 1925.25 & $15.61 \%$ \\
\hline $4-5$ & 9436 & 2359 & $19.12 \%$ \\
\hline $5-6$ & 10649 & 2662.25 & $21.58 \%$ \\
\hline
\end{tabular}




\begin{tabular}{|c|c|c|c|}
\hline $6-7$ & 11650 & 2912.5 & $23.61 \%$ \\
\hline $7-8$ & 3398 & 849.5 & $6.89 \%$ \\
\hline $8-9$ & 666 & 166.5 & $1.35 \%$ \\
\hline$>9$ & 106 & 26.5 & $0.21 \%$ \\
\hline
\end{tabular}

*Velocity is calculated at each computational node and represents an area of 0.25 square feet.

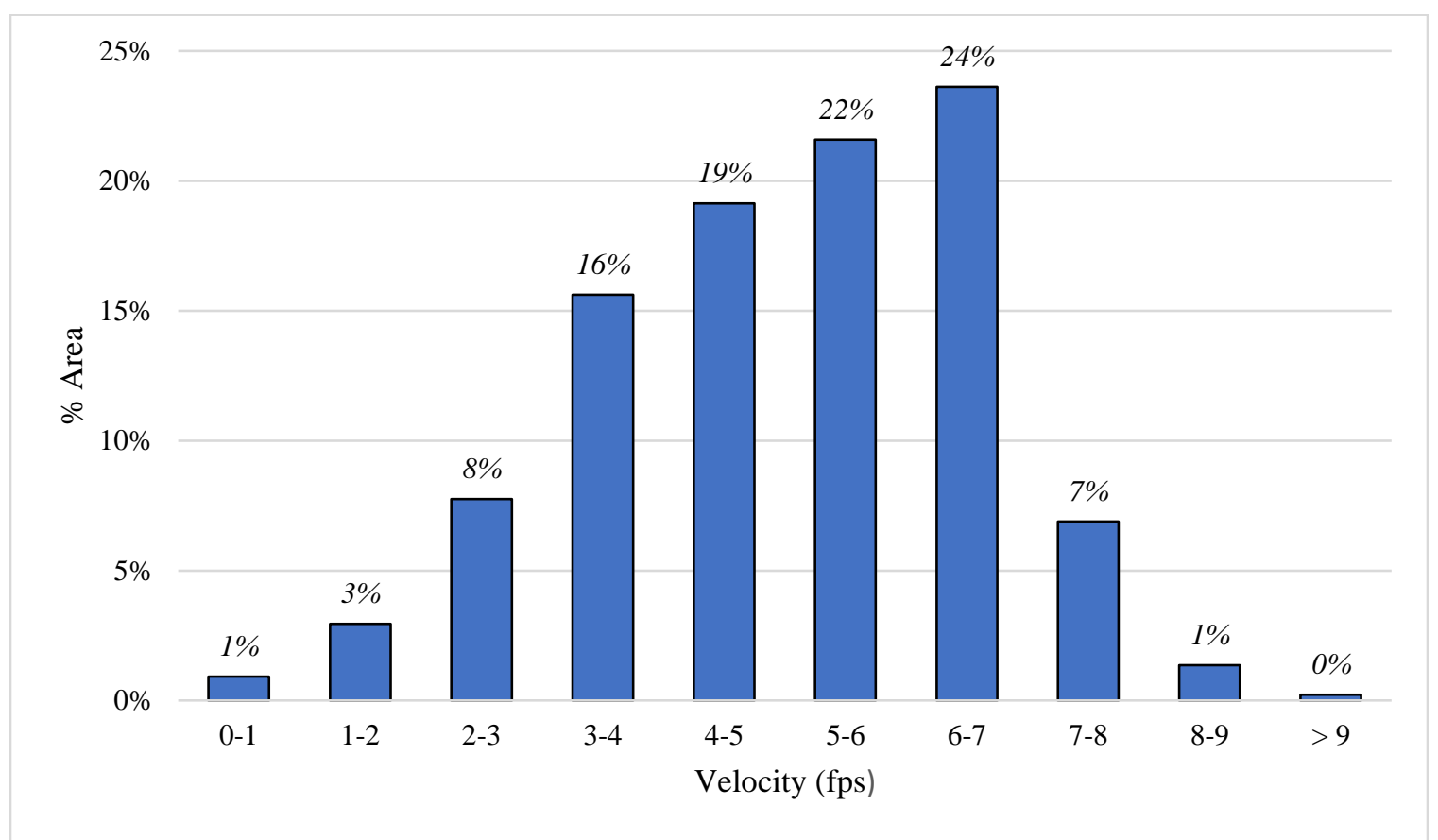

Figure 18. The percentage of area for different velocity categories for channel-Slabcamp Creek Table 25. Descriptive statistics of velocity for channel - Slabcamp Creek

\begin{tabular}{|c|c|}
\hline \multicolumn{2}{|c|}{ Velocity $(\boldsymbol{f p s})$} \\
\hline Mean & 5.02 \\
\hline Median & 5.19 \\
\hline Standard Deviation & 1.60 \\
\hline Max & 9.64 \\
\hline Min & 0.01 \\
\hline
\end{tabular}




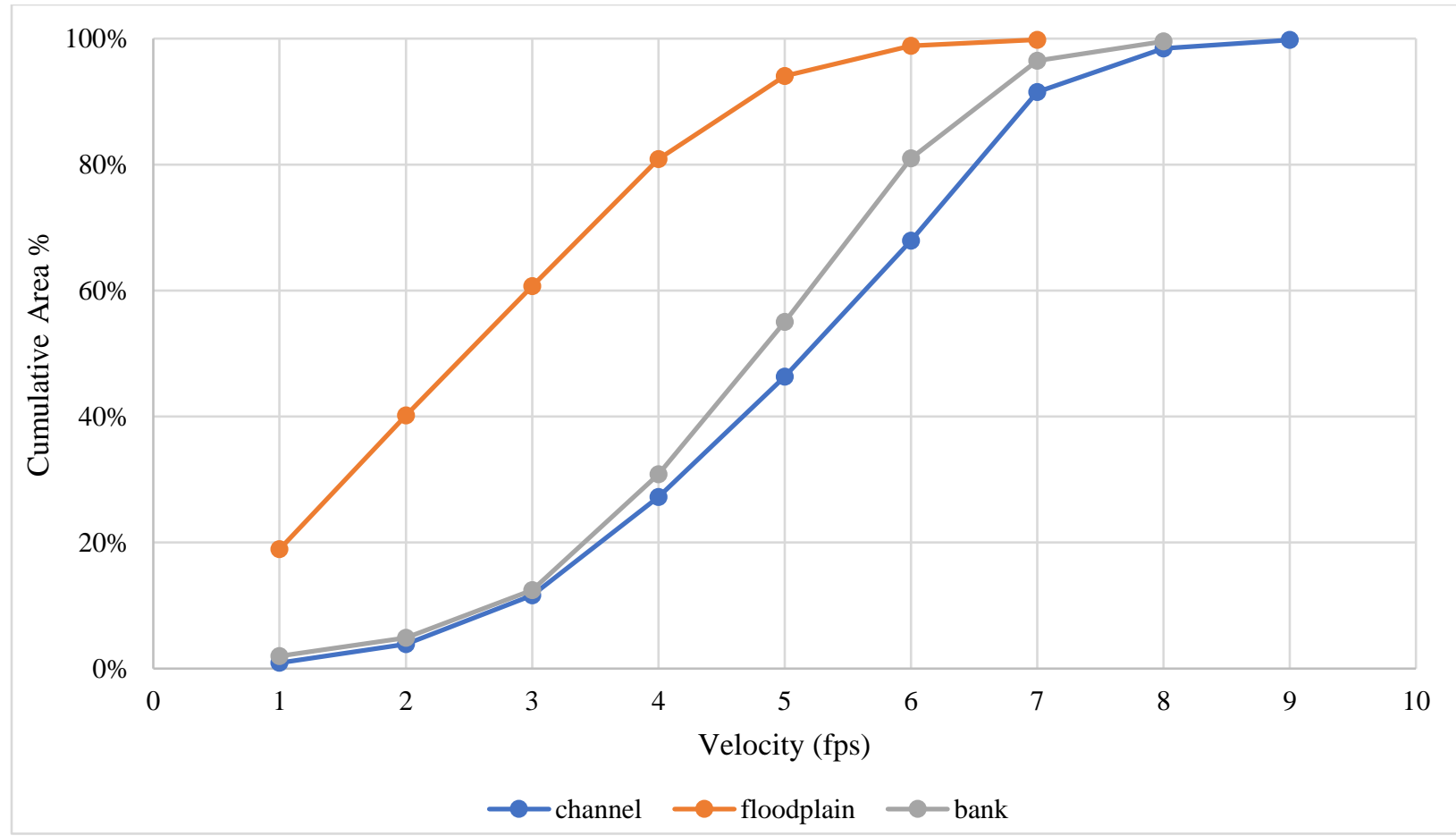

Figure 19. The cumulative percentage of area for different velocity categories for all parts - Slabcamp Creek

\subsubsection{Aggregate Statistical Characteristics of Model Shear Stress Distribution}

The result of a general statistical description of the modeled shear stress distributions over the floodplain, banks and channel were provided statistically (Table 26 to Table 31 and Figure 20 to Figure 23). In the tables the frequency of computational nodes and the percent of area in shear stress intervals of 1.0 psf were computed from the model results separately for floodplain areas, channel areas, and channel bank area.

$82 \%$ of wetted area on floodplain has the shear stress less than 2 psf. About $0.13 \%$ of wetted area on the floodplain has the shear stress greater than 6 psf. The maximum value is 9.01 psf. For the banks, these percentages increased: $70 \%$ of the wetted area on the bank has shear stress less than 3 psf. Although the average stress on the banks was higher that of the floodplain, the maximum value of the shear stress on the bank (8.65 psf) is less than the floodplain. The percentage of bank area greater than $6 \mathrm{psf}$ is $1.01 \%$ and is 
more than the floodplain. As expected, the shear stress in the channel is low compared to the banks and floodplain: about $95 \%$ of the its area has the shear stress less than 2 psf.

\section{Floodplain}

Table 26. Numerical results of shear stress distribution for floodplain - Slabcamp Creek

\begin{tabular}{|c|c|c|c|}
\hline Shear Stress (psf) & Node Frequency & Area $\left(\boldsymbol{f t}^{2}\right)$ & \% Area \\
\hline $0-1$ & 255840 & 63960 & $57.09 \%$ \\
\hline $1-2$ & 113013 & 28253.25 & $25.22 \%$ \\
\hline $2-3$ & 54167 & 13541.75 & $12.09 \%$ \\
\hline $3-4$ & 18000 & 4500 & $4.02 \%$ \\
\hline $4-5$ & 5107 & 1276.75 & $1.14 \%$ \\
\hline $5-6$ & 1409 & 352.25 & $0.31 \%$ \\
\hline$>6$ & 586 & 146.5 & $0.13 \%$ \\
\hline
\end{tabular}

* Shear stress is calculated at each computational node and represents an area of 0.25 square feet.

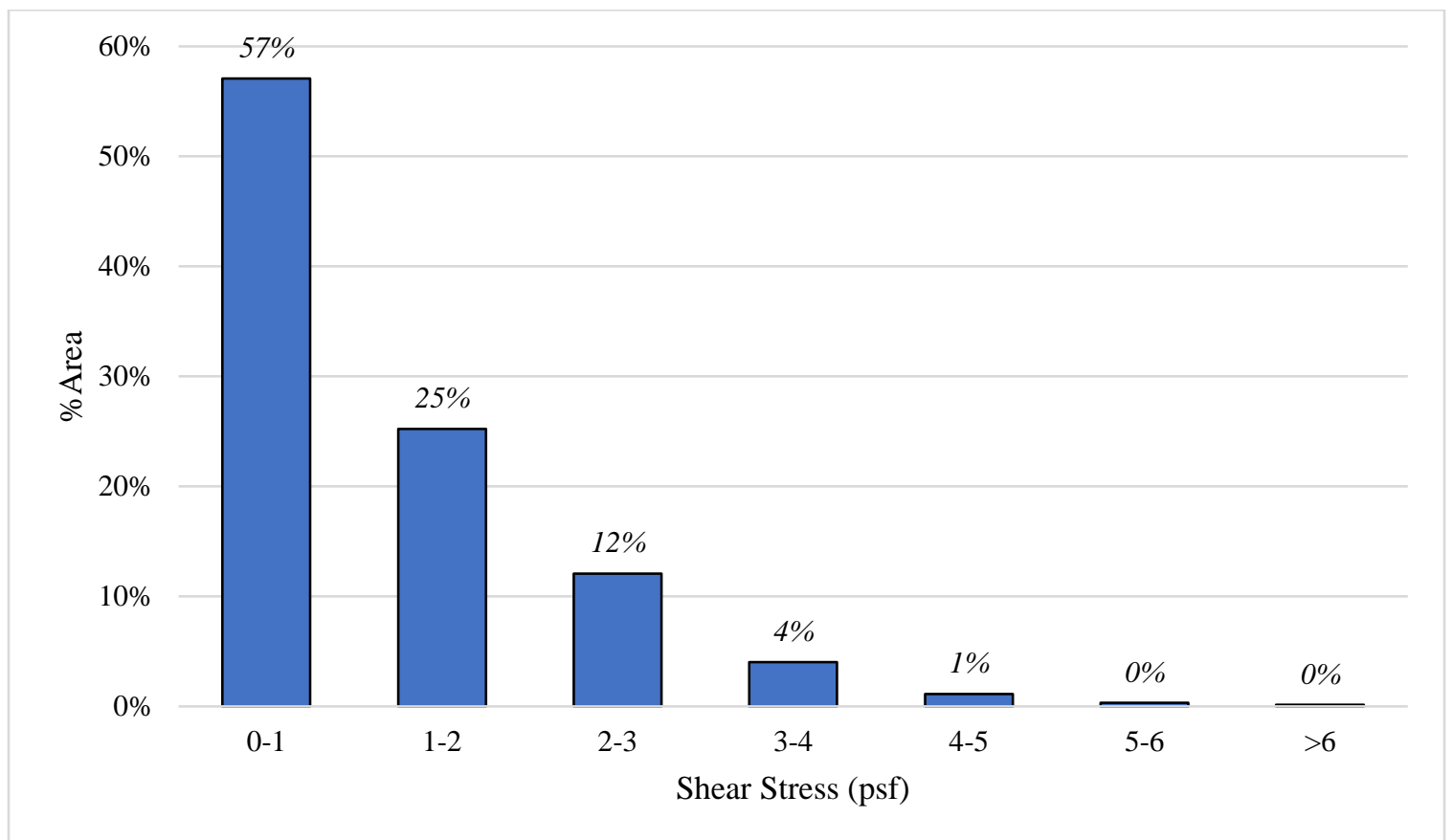

Figure 20. The percentage of area for different shear stress categories for floodplain-Slabcamp Creek Table 27. Descriptive statistics of shear stress for floodplain-Slabcamp Creek

\begin{tabular}{|c|c|}
\hline \multicolumn{2}{|c|}{ Shear Stress $(\boldsymbol{p s} \boldsymbol{f})$} \\
\hline Mean & 1.08 \\
\hline Median & 0.79 \\
\hline Standard Deviation & 1.04 \\
\hline Max & 9.01 \\
\hline Min & 0 \\
\hline
\end{tabular}




\section{Banks}

Table 28. Numerical results of shear stress distribution for banks - Slabcamp Creek

\begin{tabular}{|c|c|c|c|}
\hline Shear Stress $(\boldsymbol{p s f})$ & Node Frequency $^{*}$ & Area $\left(\boldsymbol{f t}^{\mathbf{2}}\right)$ & \% Area \\
\hline $0-1$ & 3683 & 920.75 & $18.75 \%$ \\
\hline $1-2$ & 5187 & 1296.75 & $26.41 \%$ \\
\hline $2-3$ & 5066 & 1266.5 & $25.79 \%$ \\
\hline $3-4$ & 3358 & 839.5 & $17.10 \%$ \\
\hline $4-5$ & 1558 & 389.5 & $7.93 \%$ \\
\hline $5-6$ & 592 & 148 & $3.01 \%$ \\
\hline$>6$ & 199 & 49.75 & $1.01 \%$ \\
\hline
\end{tabular}

* Shear stress is calculated at each computational node and represents an area of 0.25 square feet.

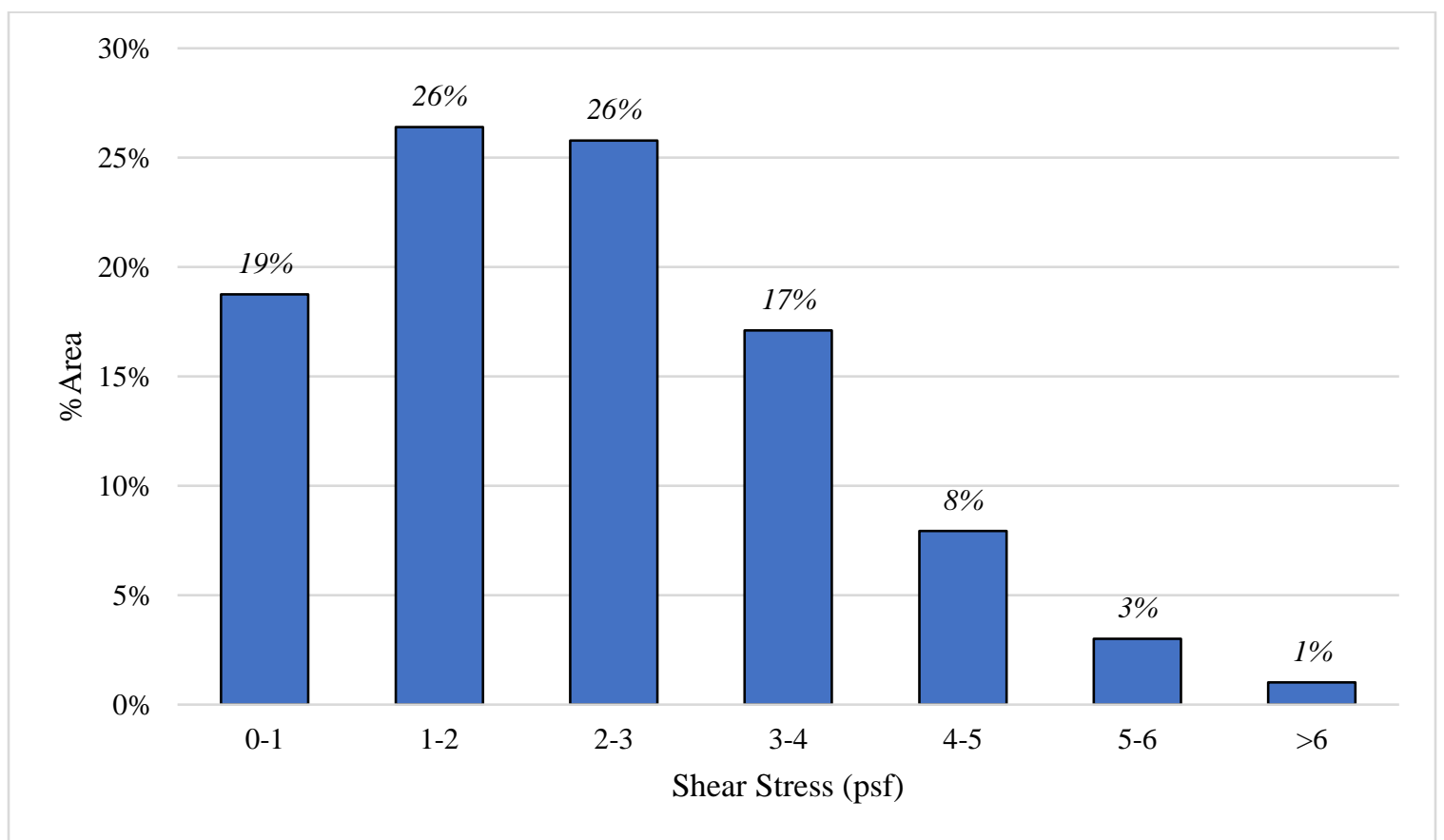

Figure 21. The percentage of area for different shear stress categories for banks - Slabcamp Creek Table 29. Descriptive statistics of shear stress for banks - Slabcamp Creek

\begin{tabular}{|c|c|}
\hline \multicolumn{2}{|c|}{ Shear Stress $(\boldsymbol{p s} \boldsymbol{f})$} \\
\hline Mean & 2.31 \\
\hline Median & 2.18 \\
\hline Standard Deviation & 1.38 \\
\hline Max & 8.65 \\
\hline Min & 0 \\
\hline
\end{tabular}

\section{Channel}

Table 30. Numerical results of shear stress distribution for channel-Slabcamp Creek

\begin{tabular}{|c|c|c|c|}
\hline Shear Stress (psf) & Node Frequency $^{*}$ & Area $\left(\boldsymbol{f t}^{2}\right)$ & \% Area \\
\hline $0-1$ & 26195 & 6548.75 & $53.09 \%$ \\
\hline $1-2$ & 20533 & 5133.25 & $41.62 \%$ \\
\hline
\end{tabular}




\begin{tabular}{|c|c|c|c|}
\hline $2-3$ & 2236 & 559 & $4.53 \%$ \\
\hline $3-4$ & 345 & 86.25 & $0.70 \%$ \\
\hline $4-5$ & 28 & 7 & $0.06 \%$ \\
\hline $5-6$ & 2 & 0.5 & $0.00 \%$ \\
\hline$>6$ & 0 & 0 & $0.00 \%$ \\
\hline
\end{tabular}

* Shear stress is calculated at each computational node and represents an area of 0.25 square feet.

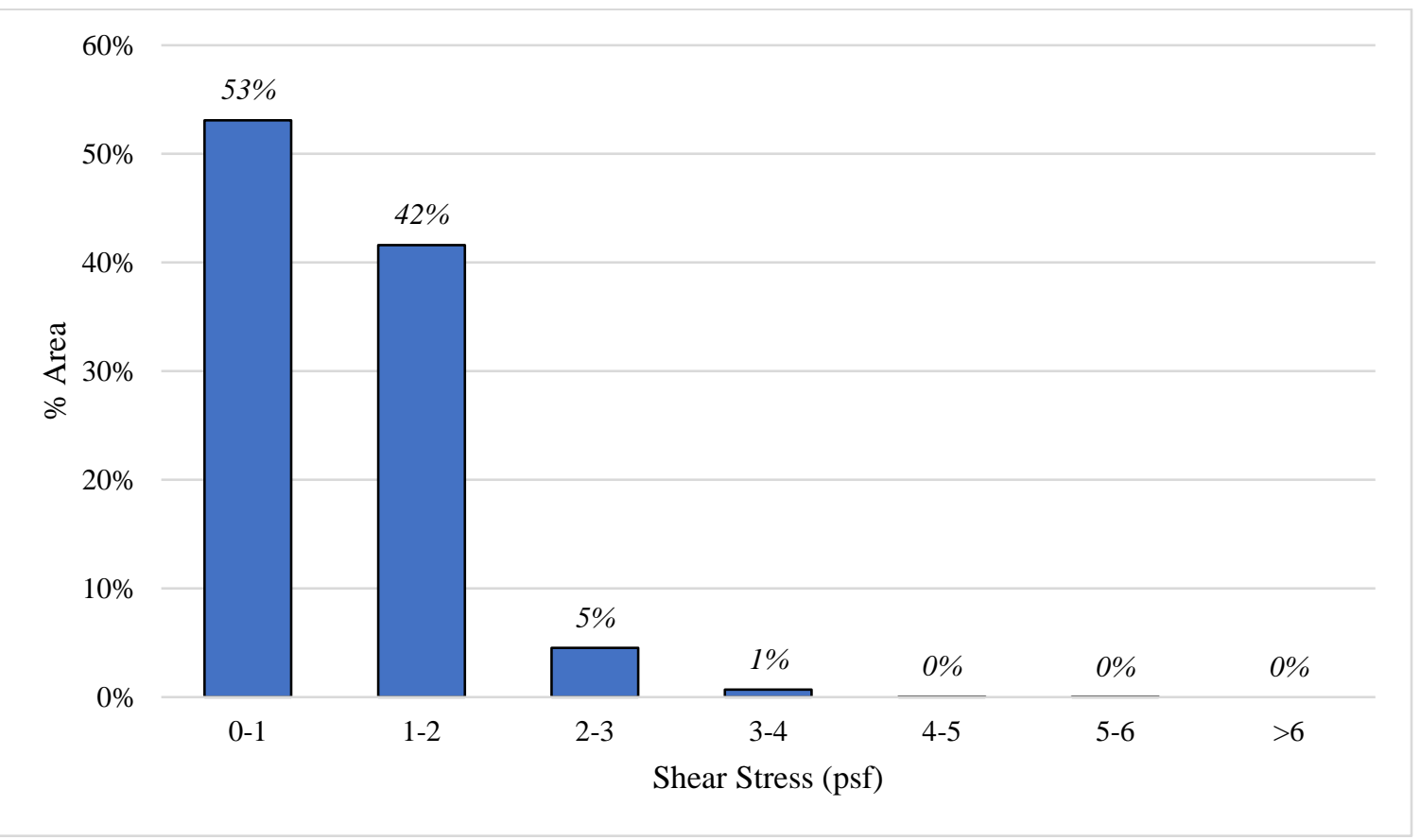

Figure 22. The percentage of area for different shear stress categories for channel-Slabcamp Creek Table 31. Descriptive statistics of shear stress for channel-Slabcamp Creek

\begin{tabular}{|c|c|}
\hline \multicolumn{2}{|c|}{ Shear Stress $(\boldsymbol{p s f})$} \\
\hline Mean & 0.99 \\
\hline Median & 0.94 \\
\hline Standard Deviation & 0.61 \\
\hline Max & 5.20 \\
\hline Min & 0 \\
\hline
\end{tabular}




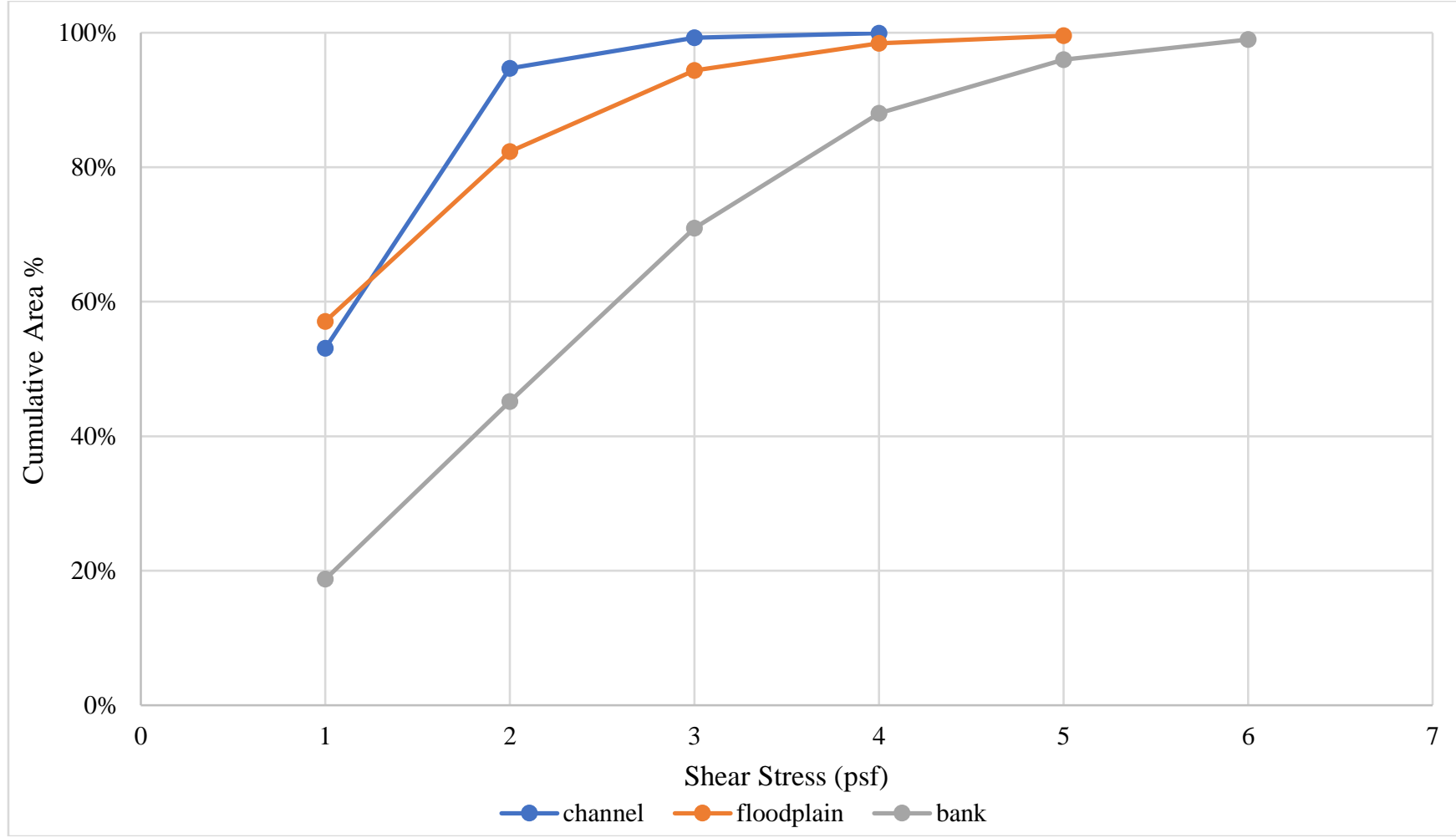

Figure 23. The cumulative percentage of area for different shear stress categories for all parts - Slabcamp Creek

\subsubsection{Brushy Creek}

Color contour maps of shear stress and velocity (Figure 24 and Figure 25) and a vector plot of the velocity direction (Figure 26) were produced. These maps also include the location of the upstream boundary conditions, the downstream boundary conditions and the section of the model that was useful for analysis. The flow development region near the upstream boundary and the region effected by the downstream boundary are also shown. Detailed analysis was conducted on the region downstream of the flow development region and upstream of the regions effected by the downstream boundary.

A large portion of the inundated area has boundary shear stress (Figure 24) less than 2 psf. Areas of higher shear stress (2-4 psf) are concentrated on banks in the floodplain were flow transfers from the channel onto the floodplain (Figure 25). In these locations the velocity vectors (Figure 26) indicate flow from the channel on to the floodplain and 
occur on outside banks in the downstream part of bends and on the floodplains downstream of those bends. The highest shear stresses (greater than $4 \mathrm{psf}$ ) were limited to banks and short sections of floodplain along those same bend areas. The most downstream reaches of the analysis area were affected by topographic confinement of the floodplain into a narrow reach that passes under a bridge. The low shear stresses on the channel, banks and floodplain in the most downstream portion of the analysis area (approximately 250 feet) were a result of the backwater effects.

The highest velocities (Figure 25) occur over the channel and along the banks, especially in the narrowest floodplain reaches. Small areas of high velocity occur on the floodplains in the same locations as high shear stresses occur - were high velocity flow transfers from the channel onto floodplain areas (Figure 25 and Figure 26). As was found in the Slabcamp model, in many locations the flow velocity above the channel bed is high and the computed shear stress on the channel bed is low. This is related to the rapid variation in roughness from the channel $(n=0.04)$ to banks and floodplains $(n=0.07)$. 


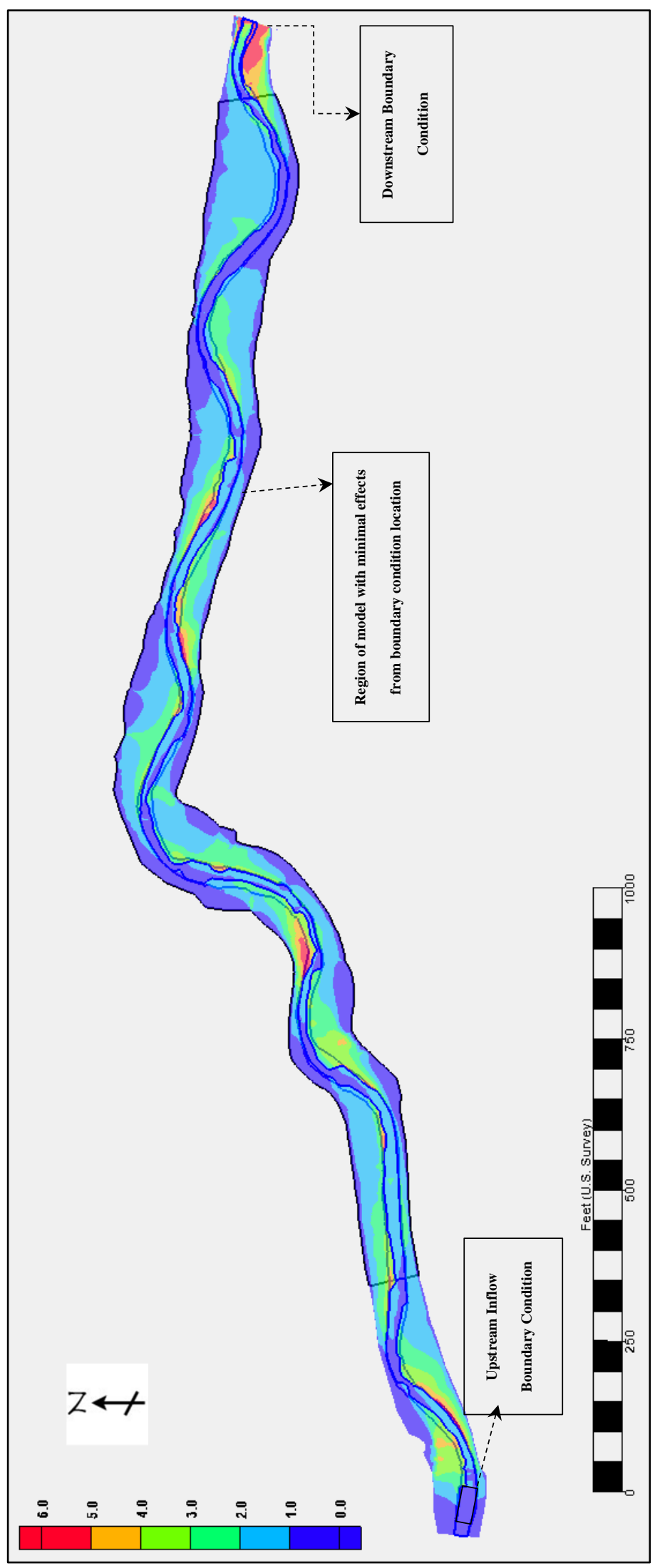

Figure 24. Brushy Creek - Shear Stress Distribution 


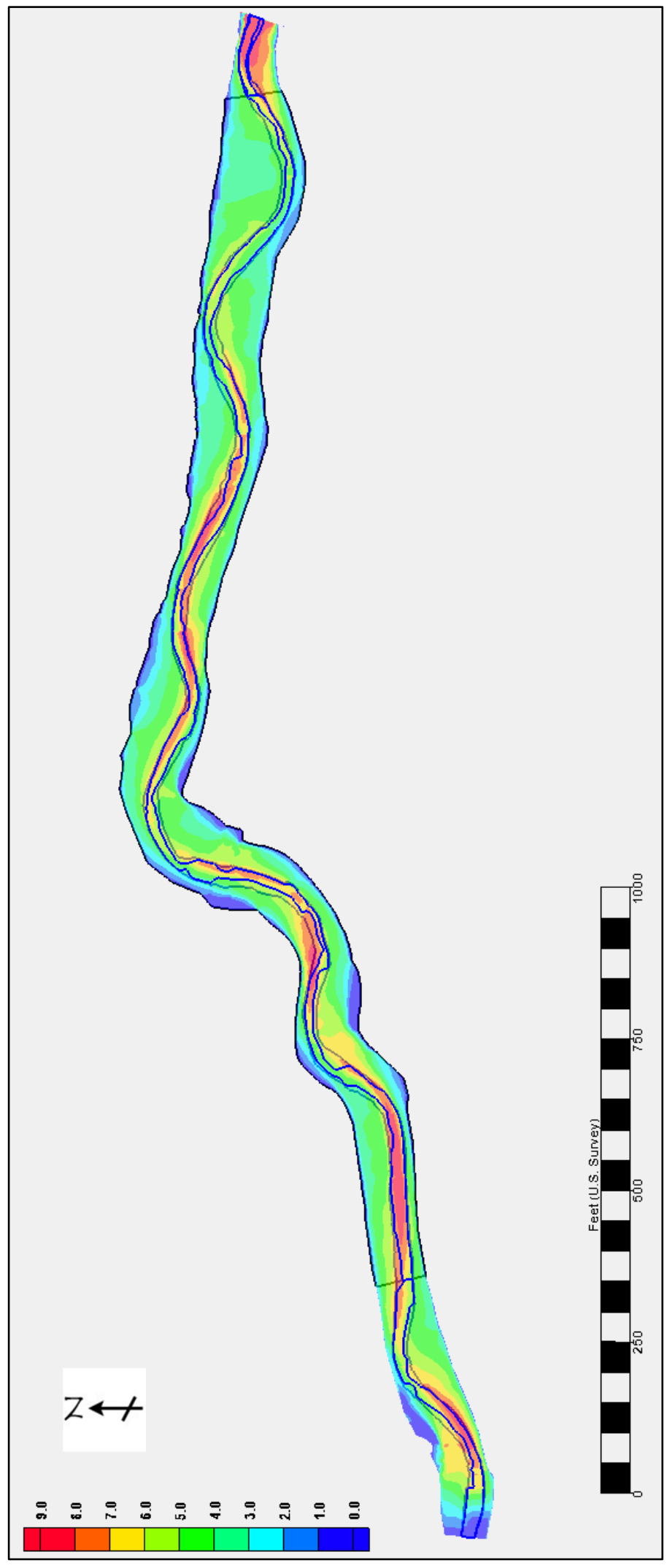

Figure 25. Brushy Creek - Velocity Distribution 


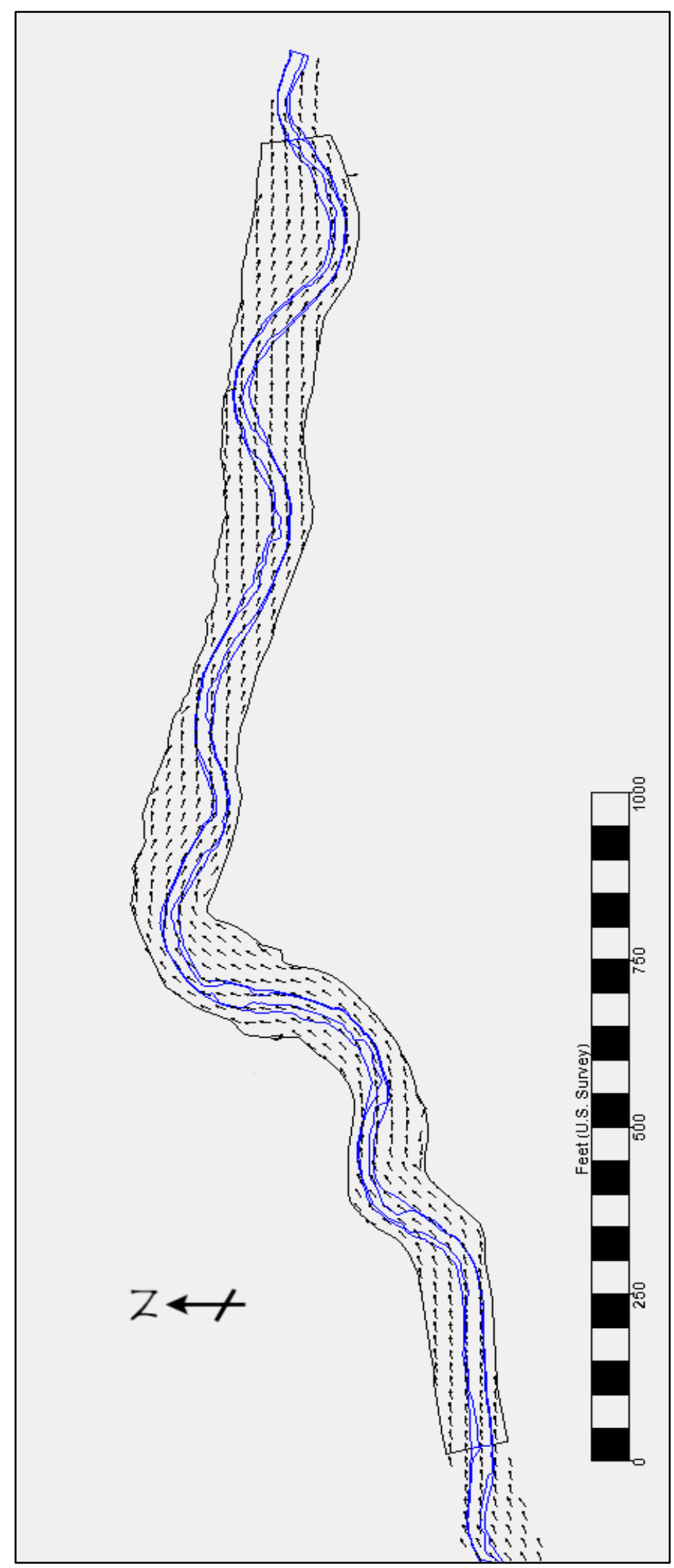

Figure 26. Brushy Creek - Velocity Vector 


\subsubsection{Aggregate Statistical Characteristics of Model Velocity Distribution}

The result of a statistical analysis of the modeled velocity distributions over the floodplain, banks and channel are provided (Table 32 to Table 37 and Figure 27 to Figure 30) In the tables the frequency of computational nodes and the percent of area in velocity intervals of 1 fps were computed from the model results separately for floodplain areas, channel areas, and channel bank area.

More than half of the wetted area on the floodplain has a velocity of less than $4 \mathrm{fps}$; about $80 \%$ of floodplain has the velocity less than $5 \mathrm{fps}$. The maximum velocity in the floodplain is $9.57 \mathrm{fps}$.

At the banks, the velocity is higher than the floodplain and more than half of the area on the banks has a velocity greater than $5 \mathrm{fps}$ and in about $22 \%$ of its area, the velocity is greater than $7 \mathrm{fps}$. The channel has the highest velocities. More than half of the channel areas had velocities in excess of $6.5 \mathrm{fps}$. Thirty six percent of the channel has the velocity greater than 7 fps. The maximum velocity computed in the channel was about $9.72 \mathrm{fps}$. The mean value in the channel $(6.33 \mathrm{fps})$ is higher than those of the banks $(5.76 \mathrm{fps})$ and floodplain (3.83 fps), respectively.

\section{Floodplain}

Table 32. Numerical results of velocity distribution for floodplain - Brushy Creek
\begin{tabular}{|c|c|c|c|}
\hline Velocity (fps) & Node Frequency & Area $\left(\boldsymbol{f t}^{2}\right)$ & $\%$ Area \\
\hline $0-1$ & 37924 & 9481 & $5.60 \%$ \\
\hline $1-2$ & 52174 & 13043.5 & $7.71 \%$ \\
\hline $2-3$ & 84506 & 21126.5 & $12.49 \%$ \\
\hline $3-4$ & 174212 & 43553 & $25.74 \%$ \\
\hline $4-5$ & 190028 & 47507 & $28.08 \%$ \\
\hline $5-6$ & 90335 & 22583.75 & $13.35 \%$ \\
\hline $6-7$ & 36606 & 9151.5 & $5.41 \%$ \\
\hline $7-8$ & 9115 & 2278.75 & $1.35 \%$ \\
\hline $8-9$ & 1926 & 481.5 & $0.28 \%$ \\
\hline
\end{tabular}




\begin{tabular}{|l|l|l|l|}
\hline$>9$ & 19 & 4.75 & $0.00 \%$ \\
\hline
\end{tabular}

*Velocity is calculated at each computational node and represents an area of 0.25 square feet.

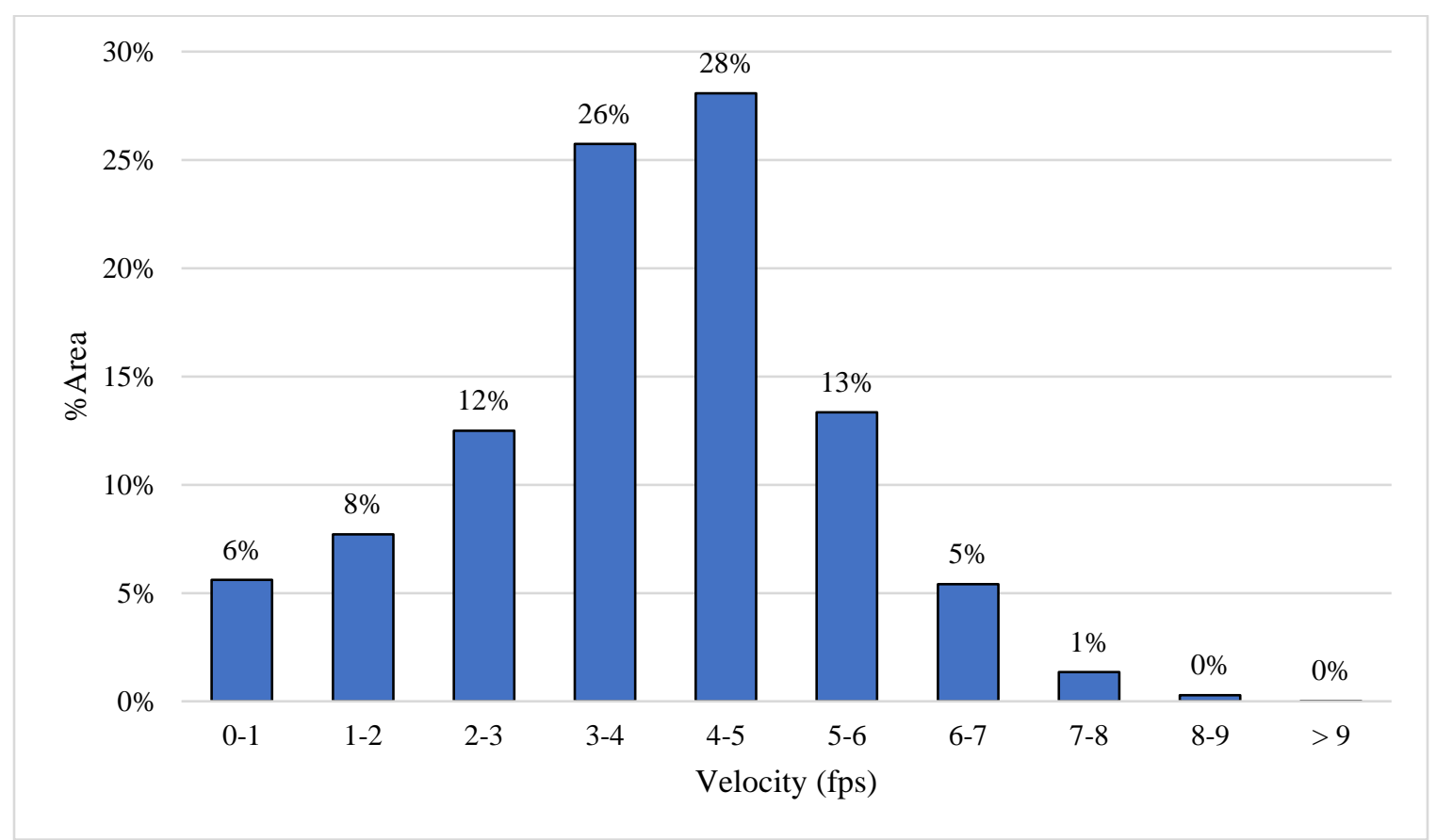

Figure 27. The percentage of area for different velocity categories for floodplain-Brushy Creek Table 33. Descriptive statistics of velocity for floodplain - Brushy Creek

\begin{tabular}{|c|c|}
\hline \multicolumn{2}{|c|}{ Velocity (fps) } \\
\hline Mean & 3.83 \\
\hline Median & 3.96 \\
\hline Standard Deviation & 1.54 \\
\hline Max & 9.57 \\
\hline Min & 0 \\
\hline
\end{tabular}

Banks

Table 34. Numerical results of velocity distribution for banks - Brushy Creek

\begin{tabular}{|c|c|c|c|}
\hline Velocity (fps) & Node Frequency & Area $\left.^{*} \boldsymbol{f t}^{2}\right)$ & \% Area \\
\hline $0-1$ & 0 & 0 & $0.00 \%$ \\
\hline $1-2$ & 0 & 0 & $0.00 \%$ \\
\hline $2-3$ & 528 & 132 & $0.64 \%$ \\
\hline $3-4$ & 6567 & 1641.75 & $7.97 \%$ \\
\hline $4-5$ & 17947 & 4486.75 & $21.78 \%$ \\
\hline $5-6$ & 23205 & 5801.25 & $28.17 \%$ \\
\hline $6-7$ & 16356 & 4089 & $19.85 \%$ \\
\hline $7-8$ & 14423 & 3605.75 & $17.51 \%$ \\
\hline $8-9$ & 3320 & 830 & $4.03 \%$ \\
\hline$>9$ & 39 & 9.75 & $0.05 \%$ \\
\hline
\end{tabular}

*Velocity is calculated at each computational node and represents an area of 0.25 square feet. 


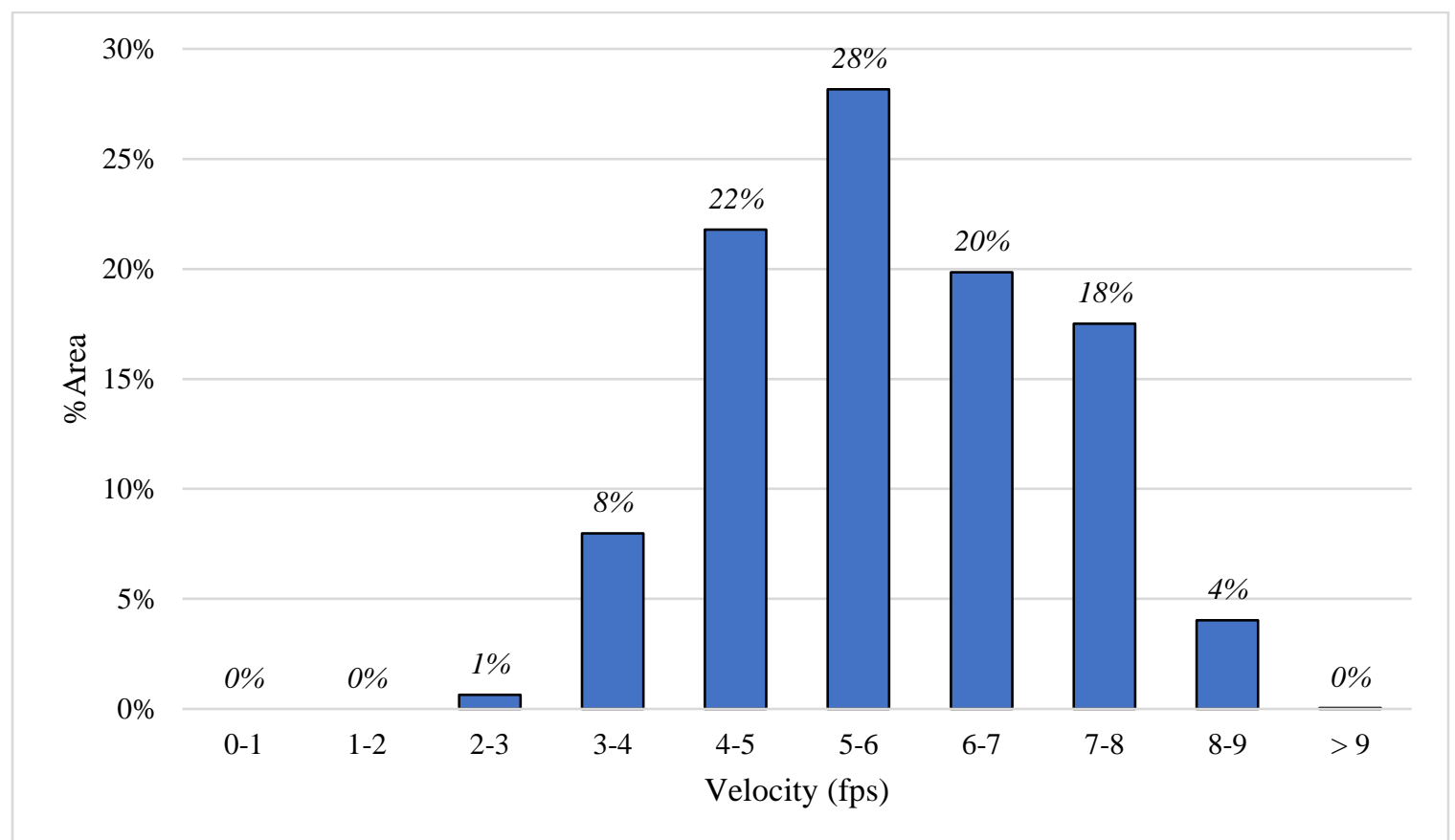

Figure 28. The percentage of area for different velocity categories for banks - Brushy Creek Table 35. Descriptive statistics of velocity for banks - Brushy Creek

\begin{tabular}{|c|c|}
\hline \multicolumn{2}{|c|}{ Velocity (fps) } \\
\hline Mean & 5.76 \\
\hline Median & 5.64 \\
\hline Standard Deviation & 1.29 \\
\hline Max & 9.71 \\
\hline Min & 2.33 \\
\hline
\end{tabular}

\section{Channel}

Table 36. Numerical results of velocity distribution for channel - Brushy Creek
\begin{tabular}{|c|c|c|c|}
\hline Velocity (fps) & Node Frequency & Area $\left(\boldsymbol{f t}^{2}\right)$ & \% Area \\
\hline $0-1$ & 0 & 0 & $0.00 \%$ \\
\hline $1-2$ & 0 & 0 & $0.00 \%$ \\
\hline $2-3$ & 380 & 95 & $0.25 \%$ \\
\hline $3-4$ & 7057 & 1764.25 & $4.73 \%$ \\
\hline $4-5$ & 20924 & 5231 & $14.03 \%$ \\
\hline $5-6$ & 30846 & 7711.5 & $20.69 \%$ \\
\hline $6-7$ & 35780 & 8945 & $23.99 \%$ \\
\hline $7-8$ & 37046 & 9261.5 & $24.84 \%$ \\
\hline $8-9$ & 16823 & 4205.75 & $11.28 \%$ \\
\hline$>9$ & 260 & 65 & $0.17 \%$ \\
\hline
\end{tabular}

*Velocity is calculated at each computational node and represents an area of 0.25 square feet. 


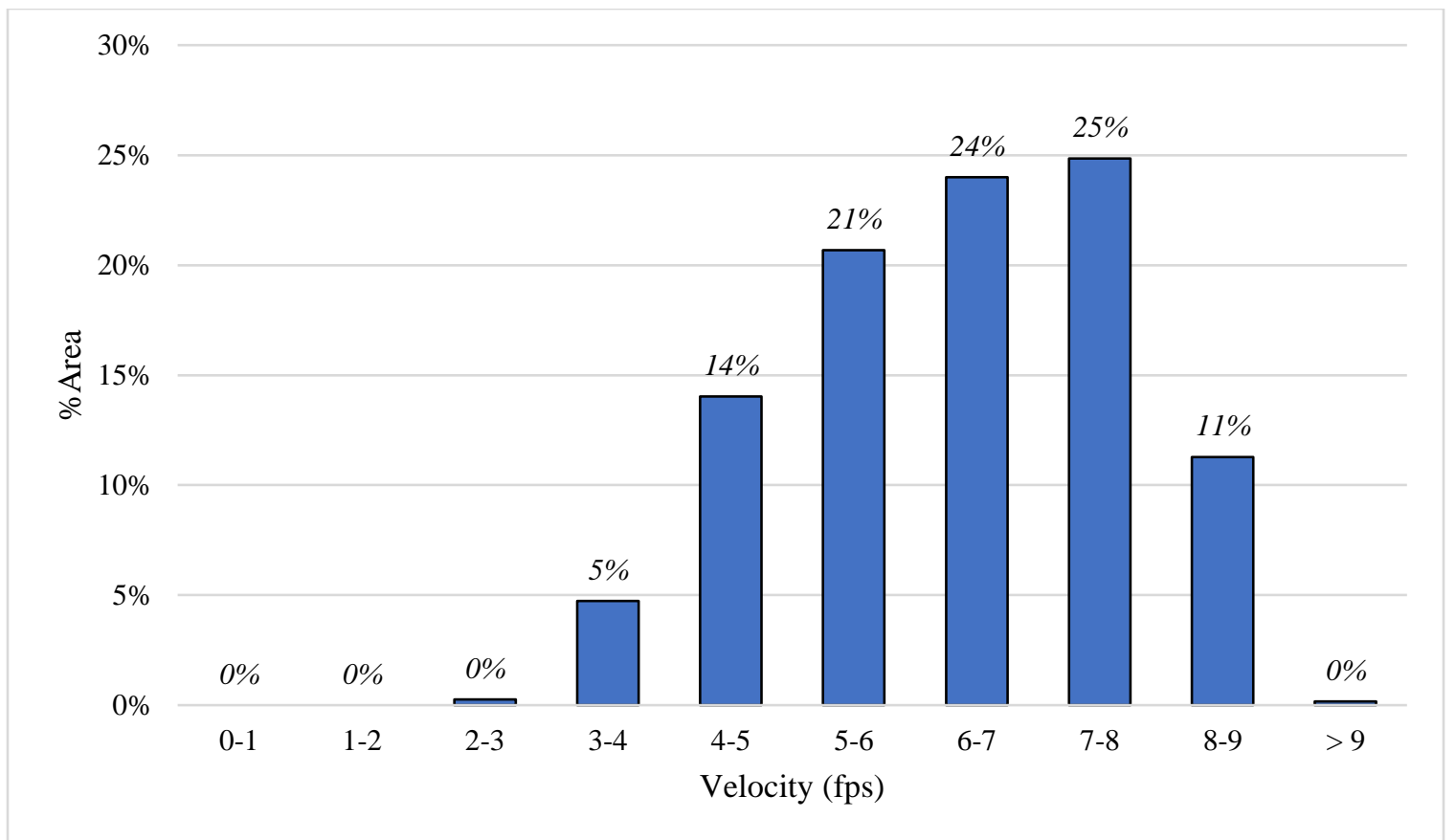

Figure 29. The percentage of area for different velocity categories for channel-Brushy Creek Table 37. Descriptive statistics of velocity for channel - Brushy Creek

\begin{tabular}{|c|c|}
\hline \multicolumn{2}{|c|}{ Velocity (fps) } \\
\hline Mean & 6.33 \\
\hline Median & 6.45 \\
\hline Standard Deviation & 1.35 \\
\hline Max & 9.72 \\
\hline Min & 2.40 \\
\hline
\end{tabular}




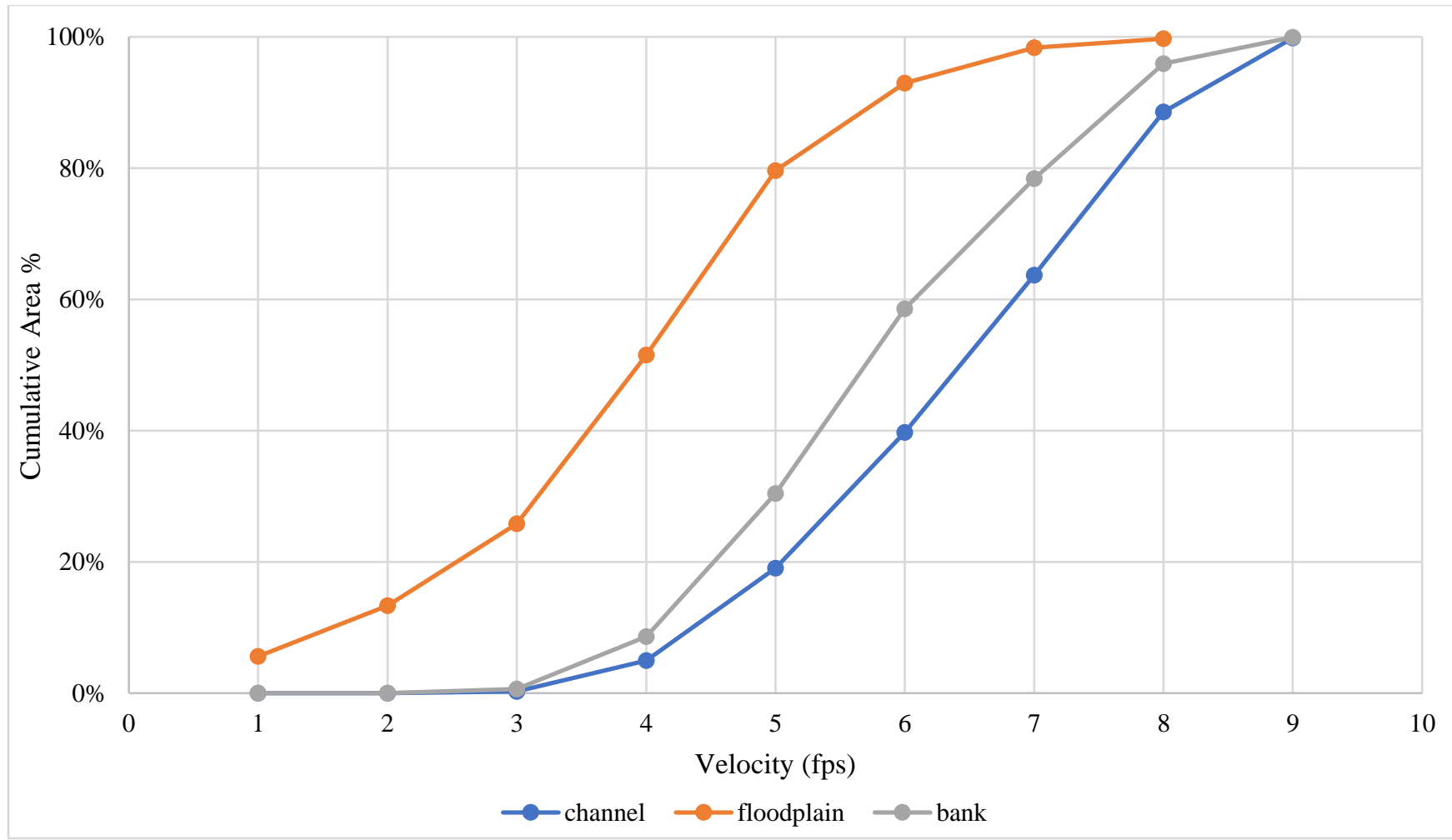

Figure 30. The cumulative percentage of area for different velocity categories for all parts - Brushy Creek

\subsubsection{Aggregate Statistical Characteristics of Model Shear Stress Distribution}

The result of a statistical analysis of the modeled shear stress distributions over the floodplain, banks and channel are provided (Table 38 to Table 43 and Figure 31 to Figure 34) In the tables the frequency of computational nodes and the percent of area in shear stress intervals of $1.0 \mathrm{psf}$ were computed from the model results separately for floodplain areas, channel areas, and channel bank area.

More than half of the wetted area on the floodplain has a shear stress of less than 1.5 psf; about $93 \%$ of floodplain has the shear stress less than 3 psf. The maximum shear stress in the floodplain is 7.25 psf although less than $1 \%$ of the floodplain area had a stress greater than 5 psf. 
At the banks, the shear stress was generally higher than the floodplain and more than half of the area on the banks had a shear stress greater than $2.6 \mathrm{psf}$ and in about $26 \%$ of its area, the shear stress was greater than 4 psf. The channel has the lowest shear stresses. More than half of the channel areas had stresses less than 1 psf and less than $0.5 \%$ of the channel area exceeded 2 psf. The mean shear stress value in the channel (1.01 psf) is lower than those of the banks (2.56 psf) and floodplain (1.50 psf), respectively.

\section{Floodplain}

Table 38. Numerical results of shear stress distribution for floodplain - Brushy Creek

\begin{tabular}{|c|c|c|c|}
\hline Shear Stress $(\boldsymbol{p s f})$ & Node Frequency $^{*}$ & Area $\left(\boldsymbol{f t}^{2}\right)$ & \% Area \\
\hline $0-1$ & 206038 & 51509.5 & $30.44 \%$ \\
\hline $1-2$ & 303135 & 75783.75 & $44.79 \%$ \\
\hline $2-3$ & 120113 & 30028.25 & $17.75 \%$ \\
\hline $3-4$ & 35344 & 8836 & $5.22 \%$ \\
\hline $4-5$ & 9059 & 2264.75 & $1.34 \%$ \\
\hline $5-6$ & 2868 & 717 & $0.42 \%$ \\
\hline$>6$ & 288 & 72 & $0.04 \%$ \\
\hline
\end{tabular}

* Shear stress is calculated at each computational node and represents an area of 0.25 square feet.

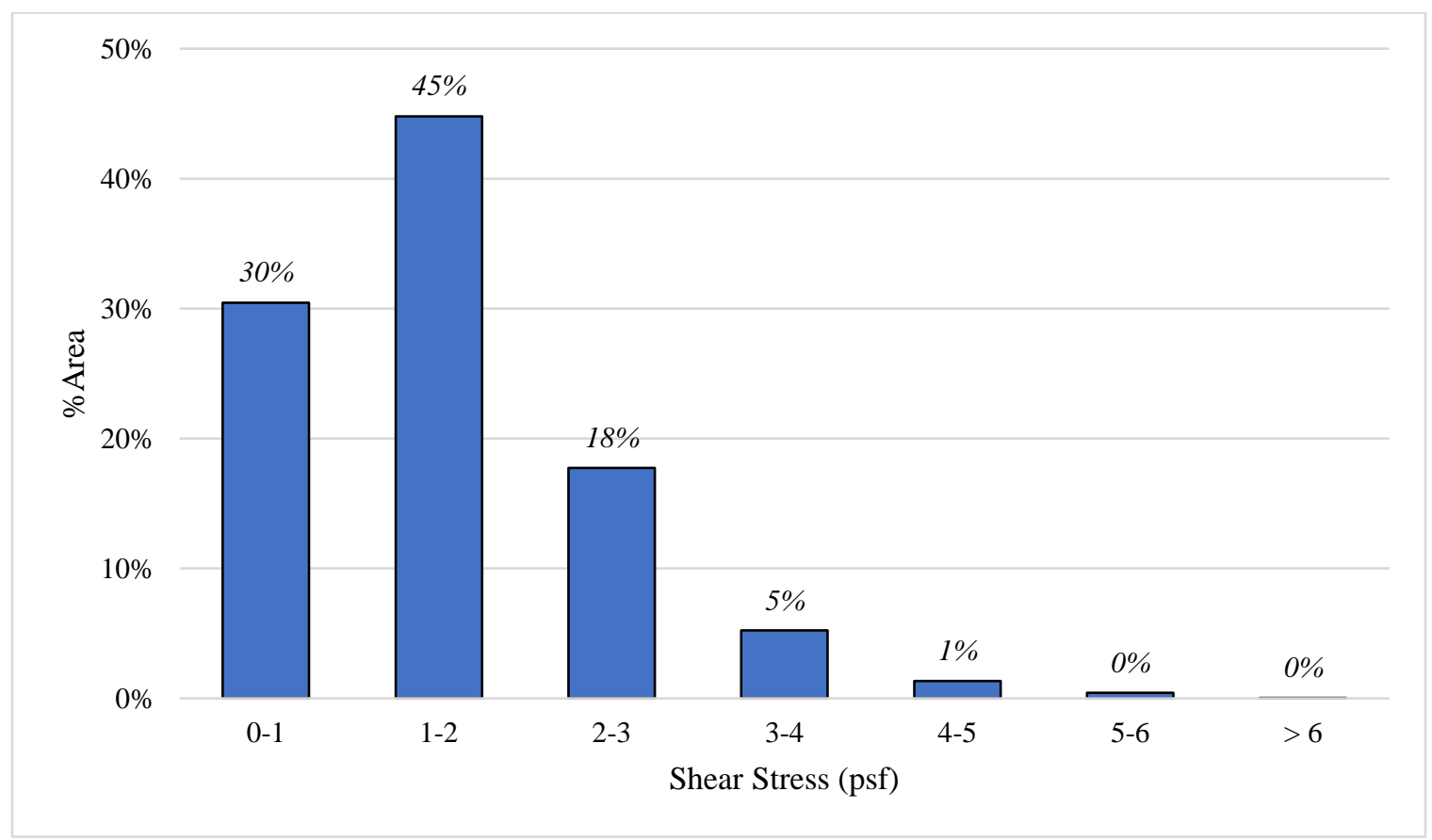

Figure 31. The percentage of area for different shear stress categories for floodplain - Brushy Creek 
Table 39. Descriptive statistics of shear stress for floodplain - Brushy Creek

\begin{tabular}{|c|c|}
\hline \multicolumn{2}{|c|}{ Shear Stress (psf) } \\
\hline Mean & 1.50 \\
\hline Median & 1.40 \\
\hline Standard Deviation & 0.95 \\
\hline Max & 7.25 \\
\hline Min & 0 \\
\hline
\end{tabular}

\section{Banks}

Table 40. Numerical results of shear stress distribution for banks-Brushy Creek

\begin{tabular}{|c|c|c|c|}
\hline Shear Stress $(\boldsymbol{p s f})$ & Node Frequency $^{*}$ & Area $^{\left(\boldsymbol{f t}^{2}\right)}$ & \% Area \\
\hline $0-1$ & 4464 & 1116 & $5.42 \%$ \\
\hline $1-2$ & 25449 & 6362.25 & $30.89 \%$ \\
\hline $2-3$ & 24846 & 6211.5 & $30.16 \%$ \\
\hline $3-4$ & 17232 & 4308 & $20.92 \%$ \\
\hline $4-5$ & 7344 & 1836 & $8.91 \%$ \\
\hline $5-6$ & 2894 & 723.5 & $3.51 \%$ \\
\hline$>6$ & 156 & 39 & $0.19 \%$ \\
\hline
\end{tabular}

*Shear stress is calculated at each computational node and represents an area of 0.25 square feet.

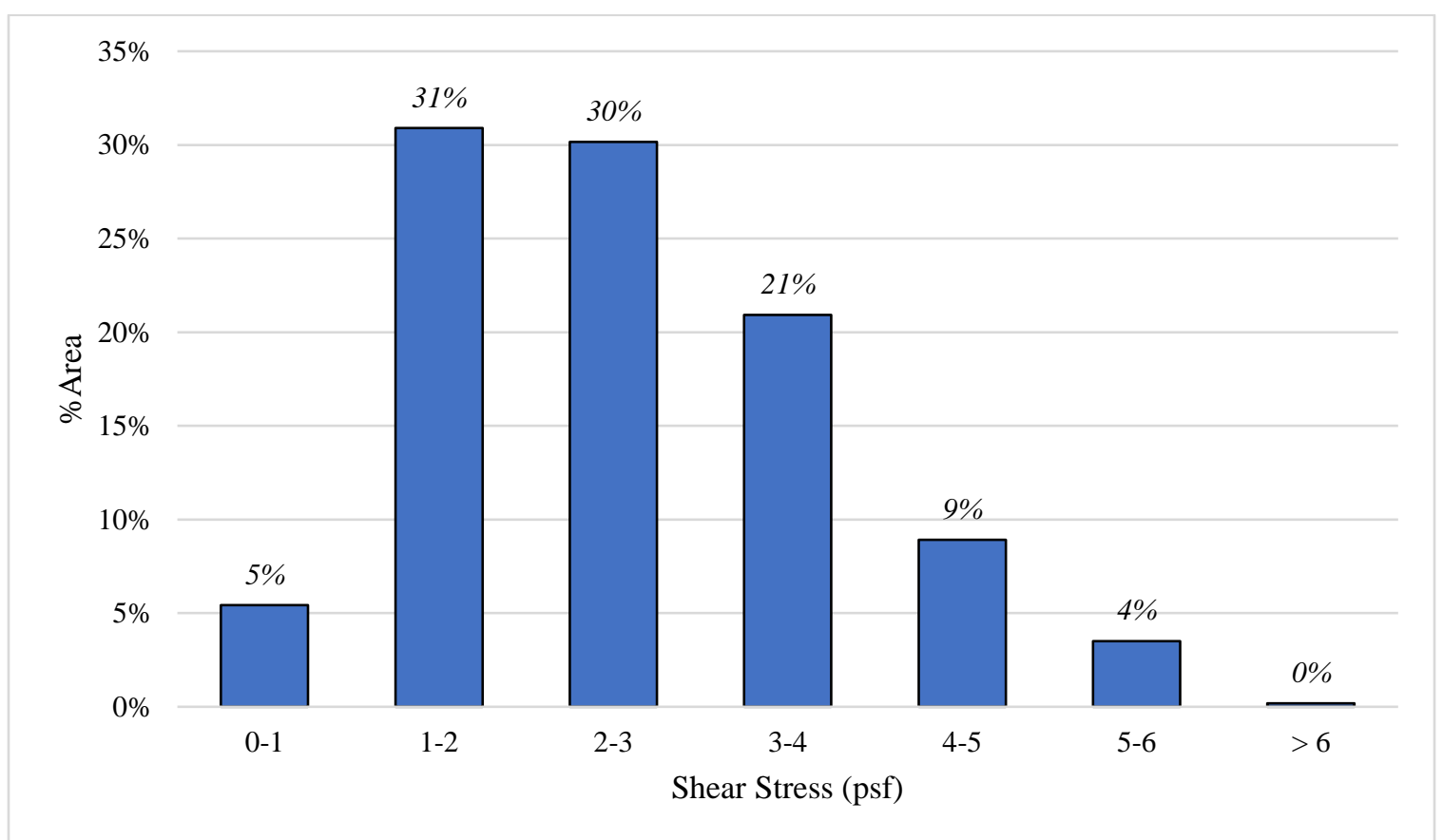

Figure 32. The percentage of area for different shear stress categories for banks - Brushy Creek Table 41. Descriptive statistics of shear stress for banks-Brushy Creek

\begin{tabular}{|c|c|}
\hline \multicolumn{2}{|c|}{ Shear Stress (psf) } \\
\hline Mean & 2.59 \\
\hline Median & 2.35 \\
\hline Standard Deviation & 1.17 \\
\hline
\end{tabular}




\begin{tabular}{|l|l|} 
Max & 7.32 \\
\hline Min & 0.21 \\
\hline
\end{tabular}

\section{Channel}

Table 42. Numerical results of shear stress distribution for channel-Brushy Creek

\begin{tabular}{|c|c|c|c|}
\hline Shear Stress (psf) & Node Frequency" & $\operatorname{Area}\left(f t^{2}\right)$ & \% Area \\
\hline $0-1$ & 75197 & 18799.25 & $50.43 \%$ \\
\hline $1-2$ & 73204 & 18301 & $49.09 \%$ \\
\hline $2-3$ & 706 & 176.5 & $0.47 \%$ \\
\hline $3-4$ & 9 & 2.25 & $0.01 \%$ \\
\hline $4-5$ & 0 & 0 & $0.00 \%$ \\
\hline $5-6$ & 0 & 0 & $0.00 \%$ \\
\hline$>6$ & 0 & 0 & $0.00 \%$ \\
\hline
\end{tabular}

*Shear stress is calculated at each computational node and represents an area of 0.25 square feet.

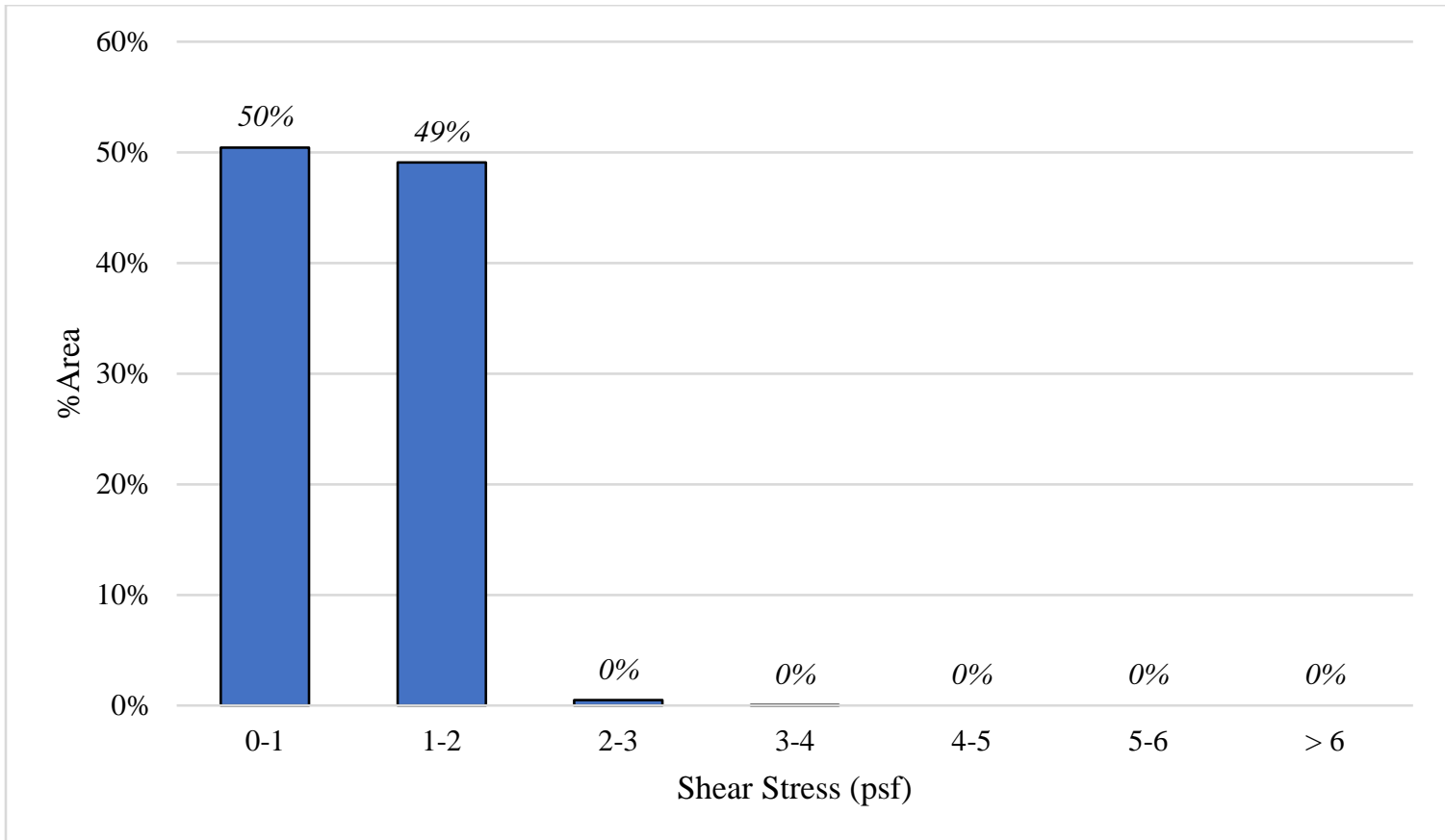

Figure 33. The percentage of area for different shear stress categories for channel-Brushy Creek Table 43. Descriptive statistics of shear stress for channel-Brushy Creek

\begin{tabular}{|c|c|}
\hline \multicolumn{2}{|c|}{ Shear Stress (psf) } \\
\hline Mean & 1.01 \\
\hline Median & 1.00 \\
\hline Standard Deviation & 0.42 \\
\hline Max & 3.13 \\
\hline Min & 0.14 \\
\hline
\end{tabular}




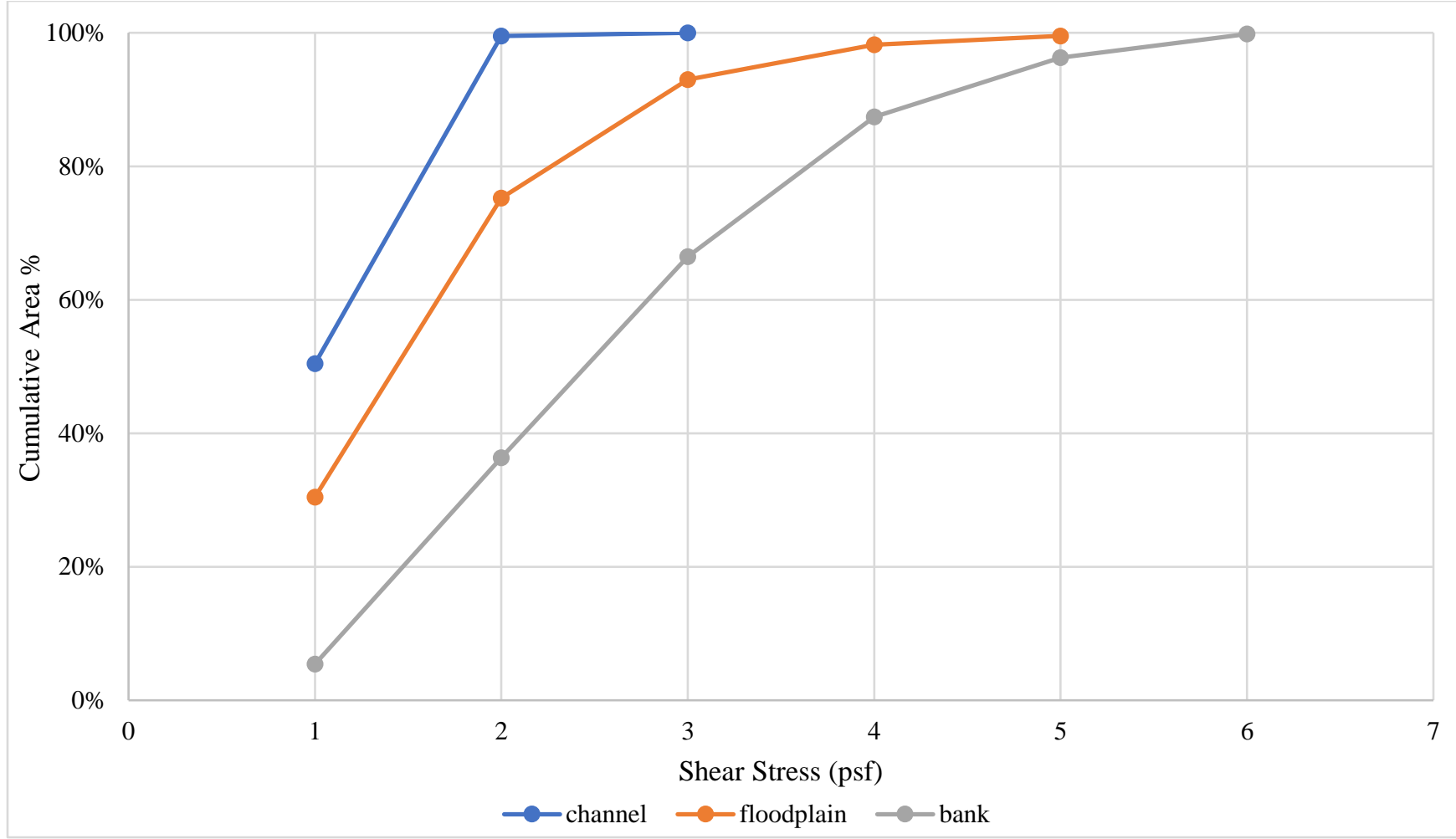

Figure 34. The cumulative percentage of area for different shear stress categories for all parts - Brushy Creek

4.4 Shear Stress, Velocity Magnitude and Occurrence of Erosion

Polygons representing areas identified as eroded based on differences between asbuilt surveyed bank lines and bank lines identified in recent aerial photographs at Slabcamp Creek (Figure 35, Figure 36 and Table 44); The differences, however, should not be interpreted as areas of active bank erosion. Bank erosion did not appear active along most of the channel banks. The bank line differences indicated that $39 \%$ of the channel bank area was eroded during the monitoring period. Most of the area identified as eroded floodplain was in close proximity to stream banks that were identified as experiencing erosion after the as-built survey. The polygons representing floodplain erosion were always adjacent to bank erosion polygons. Several errors may have been responsible for error in the determination of bank erosion. 1) differences in methods of determining the bank line, 
2) areas where vegetation was removed caused by invasive vegetation management, 3) buried by silt misinterpreted as eroded areas, 3) errors in as-built surveys, 4) freeze thaw degradation of banks rather than shear stress of channels. These errors are particularly important in the case of bank erosion because area of the banks is very narrow, on the order of 1 to 5 feet.

In Brushy Creek (Figure 37, Figure 38 and Table 45), extensive lateral channel movement or channel avulsion in combination with large sediment deposits in areas identified in the design as channel, banks, and floodplain complicated the interpretation of eroded areas: some channels, banks and floodplains may have been buried rather than eroded and some floodplain areas may have been eroded through a bank erosion process, rather than vertical degradation of the floodplain. Changes in the channel, banks, and floodplain topography were changed significantly from the as-built topography. Bank erosion was indicted along $51 \%$ of the banks identified in the as-built condition and $32 \%$ of the floodplain was identified as eroded. 


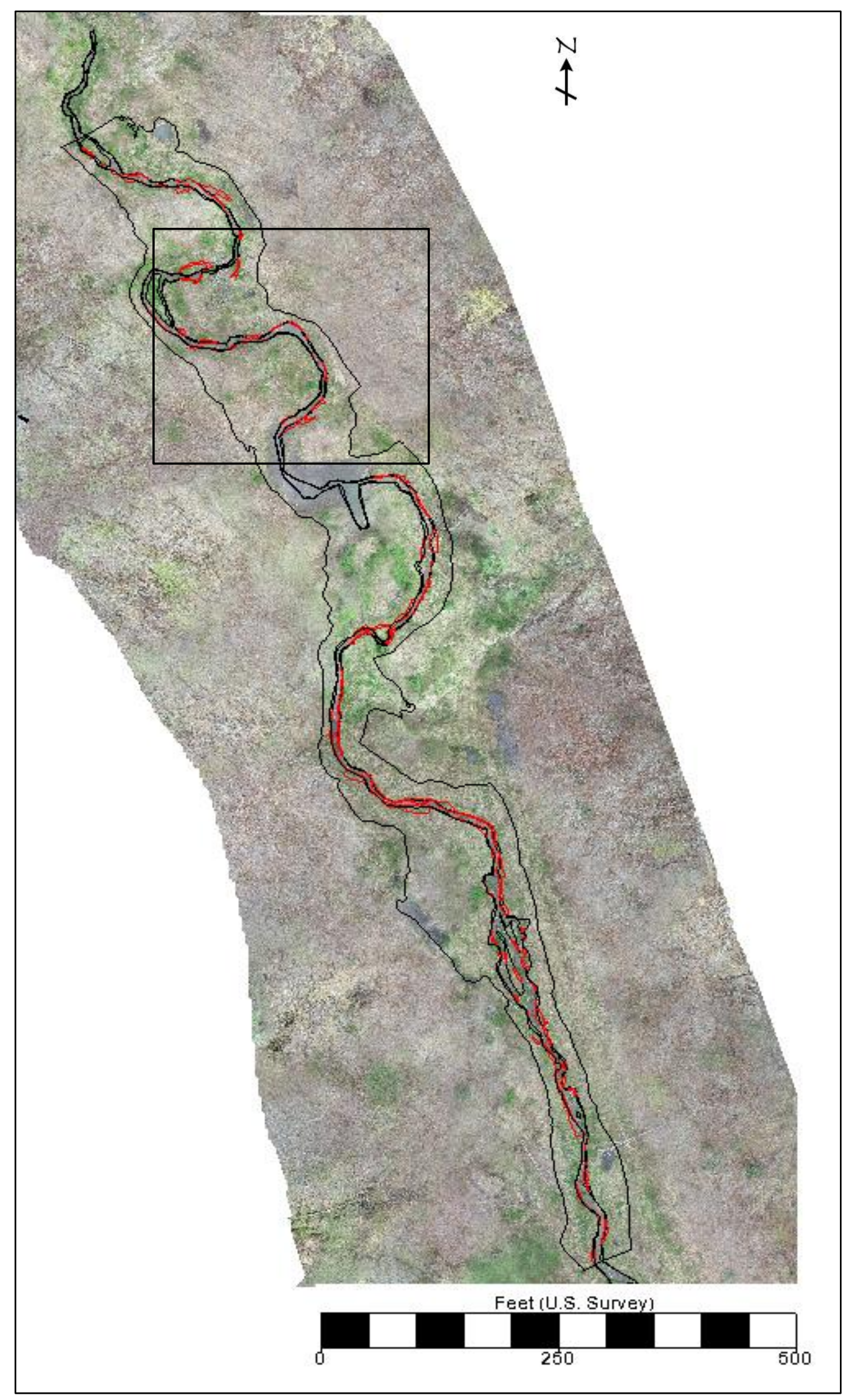

Figure 35. Eroded spots in Slabcamp Creek, Red polygons indicate area of erosion 


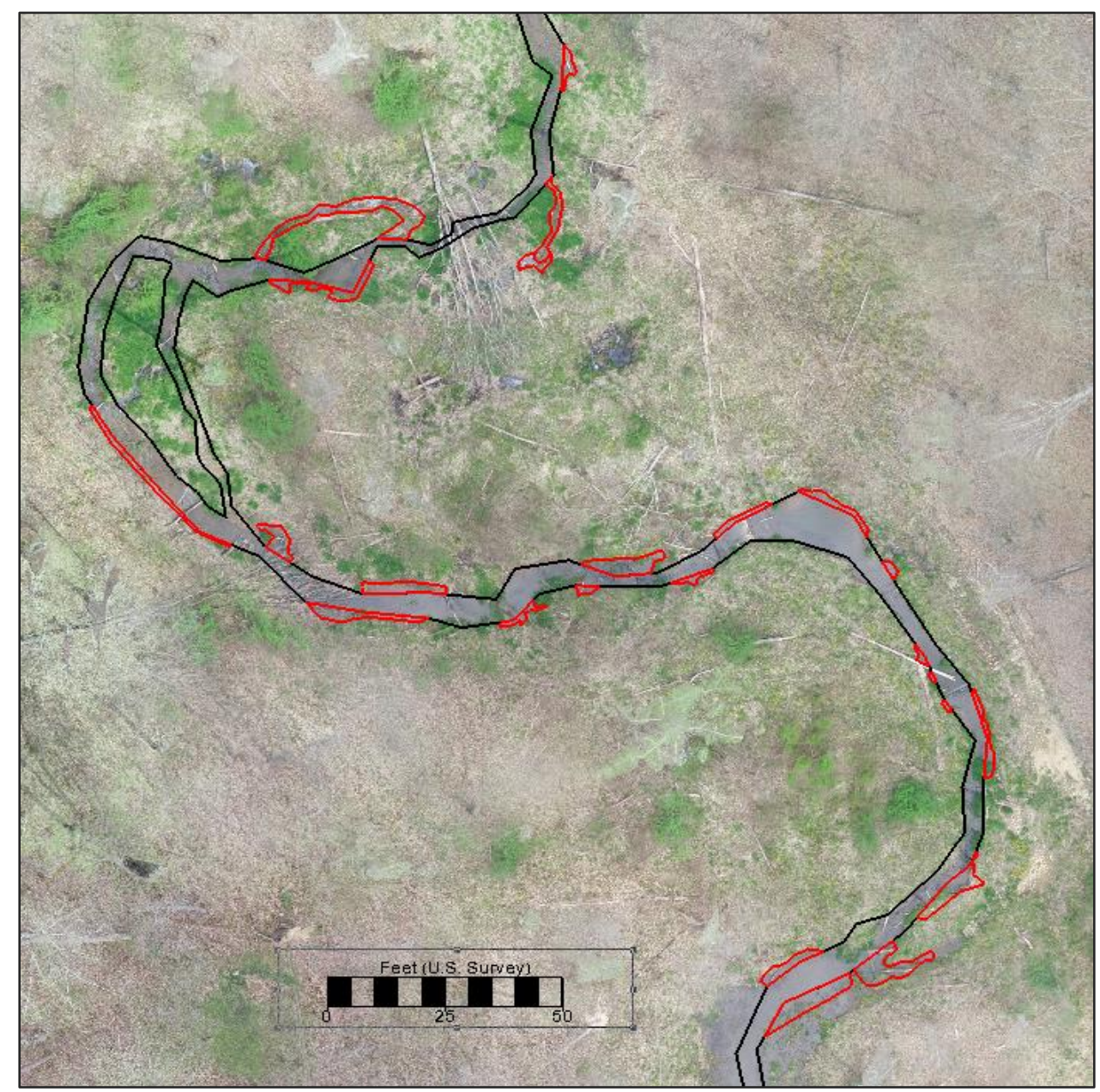

Figure 36. Eroded spots in Slabcamp Creek. Red polygons indicate area of erosion. Table 44. The percentage of each area from total wet area-Slabcamp Creek

\begin{tabular}{|c|c|c|}
\hline & Area $\left(\mathrm{ft}^{2}\right)$ & $\%$ Wet Area \\
\hline Wet Area & 130863 & 100.00 \\
\hline Channel & 12318 & 9.41 \\
\hline Bank & 4924 & 3.76 \\
\hline Floodplain & 113621 & 86.82 \\
\hline Eroded Bank & 1913 & 1.46 \\
\hline Eroded Floodplain & 2565 & 1.96 \\
\hline
\end{tabular}




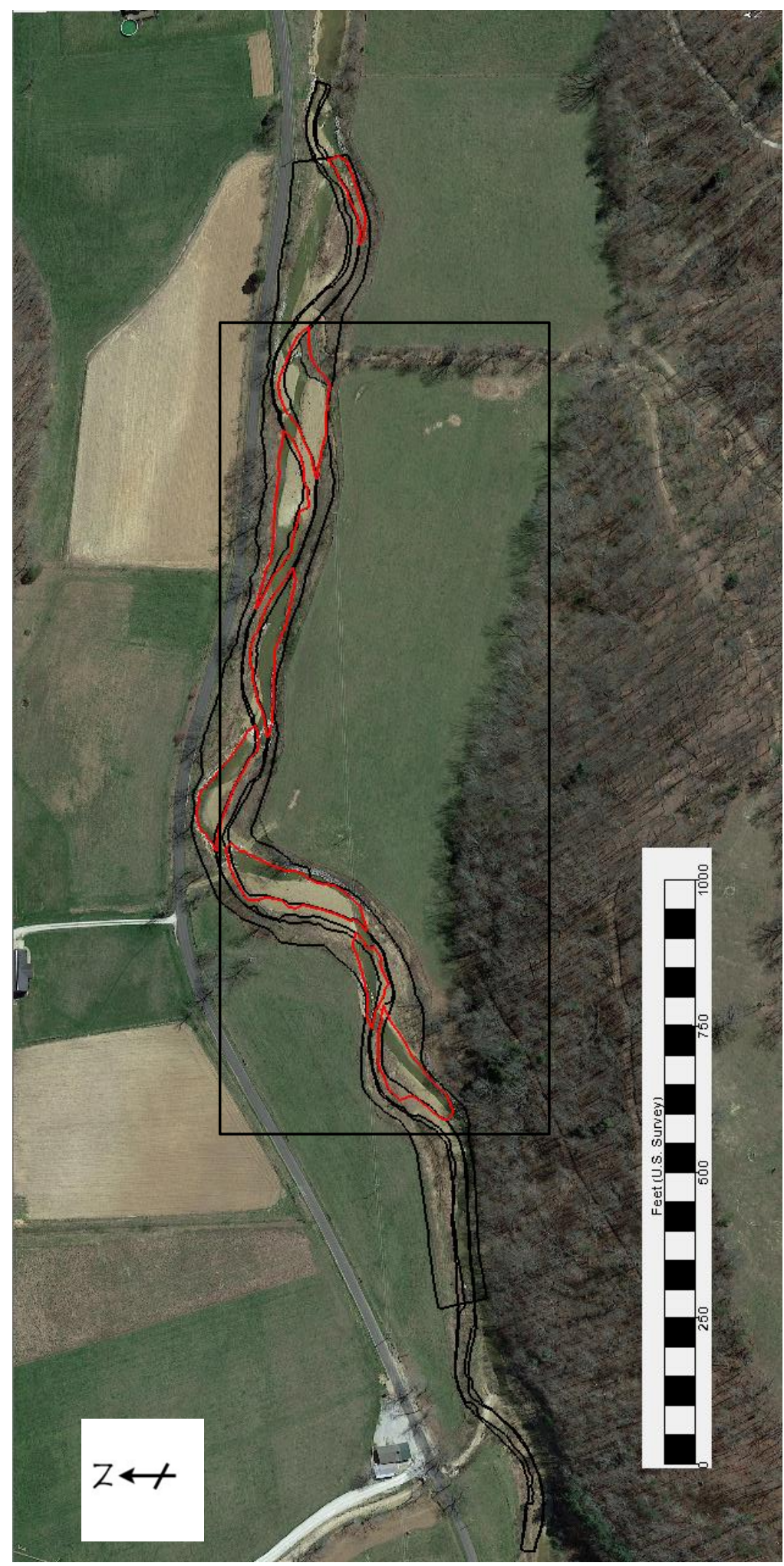

Figure 37. Eroded areas in Brushy Creek. Red polygons represent areas identified as areas of erosion. 


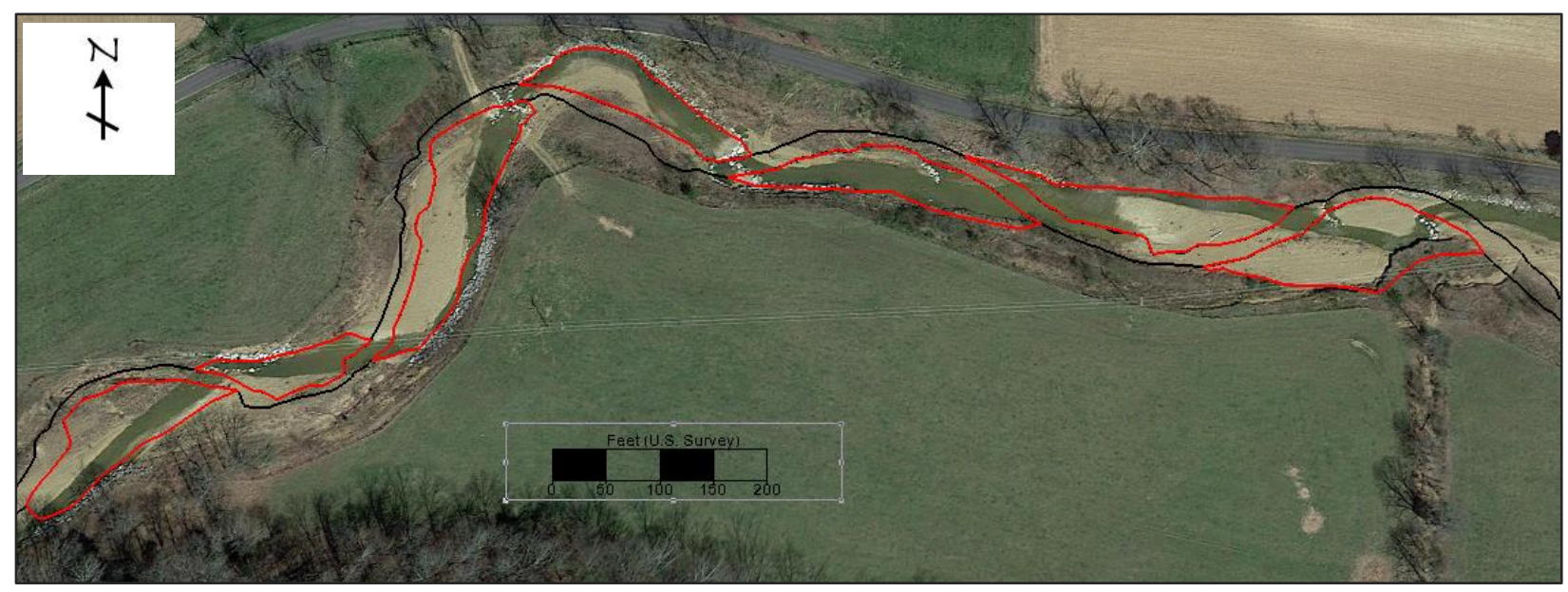

Figure 38. Eroded areas in Brushy Creek. Red polygons represent areas identified as erosion Table 45. The percentage of each area from total wet area - Brushy Creek

\begin{tabular}{|c|c|c|}
\hline & Area $\left(\mathrm{ft}^{2}\right)$ & $\%$ Wet Area \\
\hline Wet Area & 227336 & 100.00 \\
\hline Channel & 37294 & 16.40 \\
\hline Bank & 20710 & 9.11 \\
\hline Floodplain & 169332 & 74.49 \\
\hline Eroded Bank & 10580 & 4.65 \\
\hline Eroded Floodplain & 54810 & 24.11 \\
\hline
\end{tabular}

4.5 Shear Stress and Velocity Magnitude and Occurrence of Bank and Floodplain Erosion

Analysis of the percentage area eroded of the combined bank and floodplain areas (Figure 39 to Figure 42) and for separate floodplain areas (Figure 43, Figure 44, Figure 47 and Figure 48) and bank areas (Figure 45, Figure 46, Figure 49 and Figure 50) indicate that banks may need to be looked at differently than floodplains. The large floodplain area overwhelms the bank area in the assessment of percentage total bank and floodplain areas. Nonetheless, the examination of results for the combined areas provides information on the total area inundated. For Slabcamp, the percentage of area eroded for modeled shear stress 
and velocities of less than 3 psf (Figure 39) and 5 fps (Figure 40), respectively are relatively small. The percent area eroded is significantly higher for shear stresses greater than $4 \mathrm{psf}$ (Figure 39) and velocity greater than 6 fps (Figure 40). For Brushy Creek the transition from areas of shear and velocity of low percentage of erosion to high percentage of erosion is more gradual: shear stress between $0 \mathrm{psf}$ and $3.5 \mathrm{psf}$ (Figure 41) and velocity between 2 and 7 fps (Figure 42). In both the Slabcamb and Brushy analysis for the combined bank and floodplain areas, shear stress over 4 psf and velocity over 6 fps showed high percentage area of erosion.

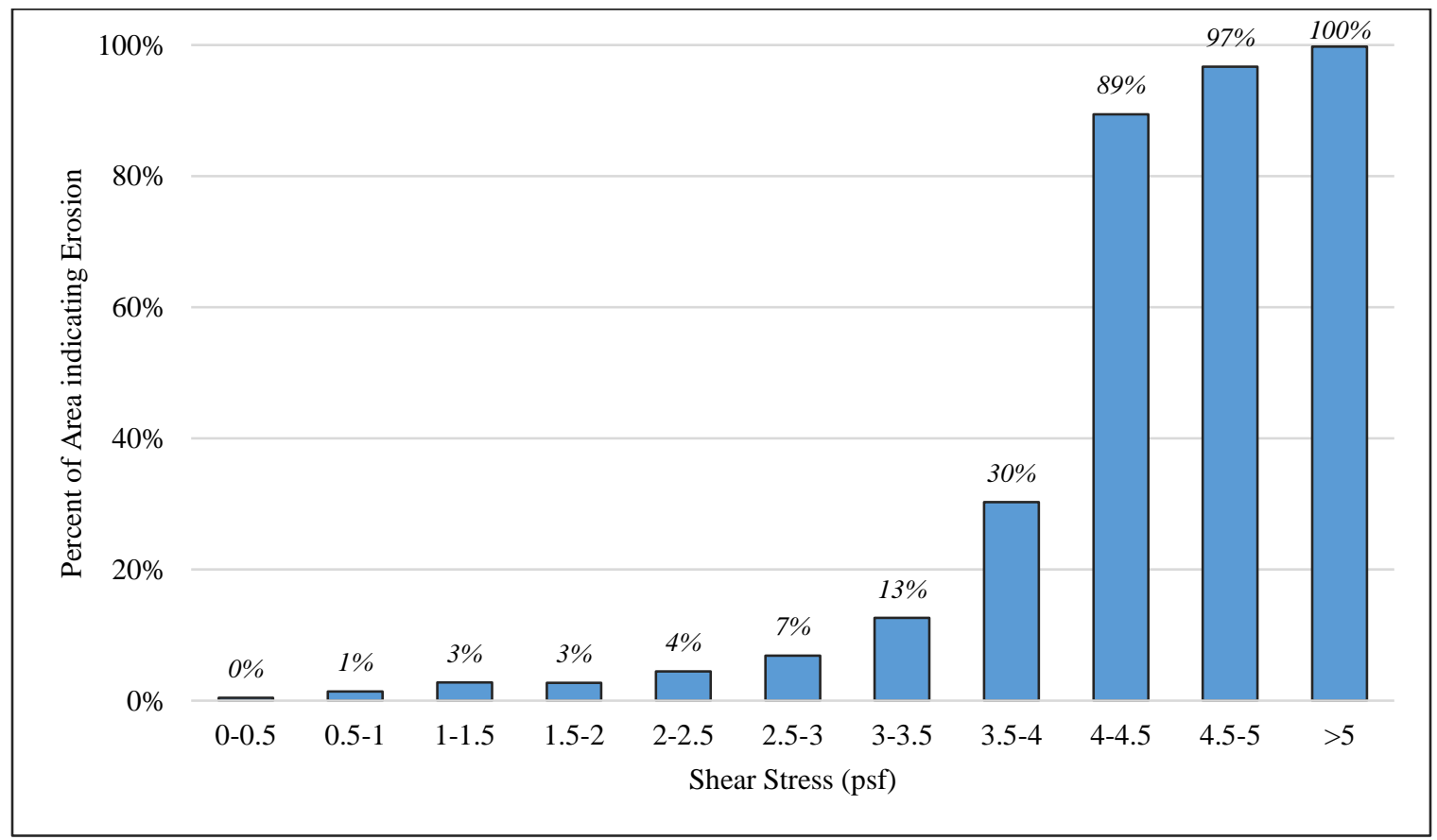

Figure 39. Banks \& Floodplains - Slabcamp Creek 


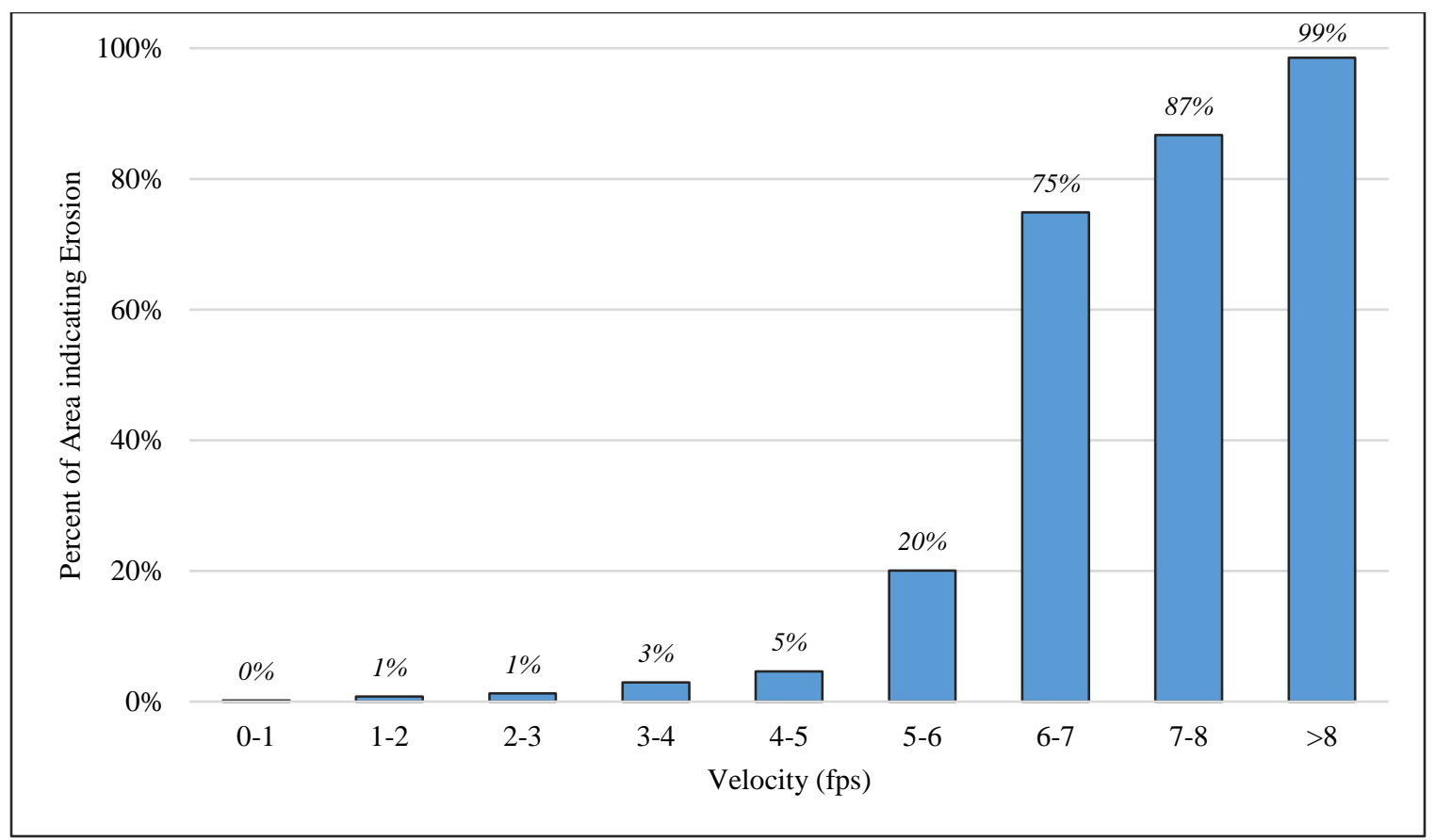

Figure 40. Banks \& Floodplains - Slabcamp Creek

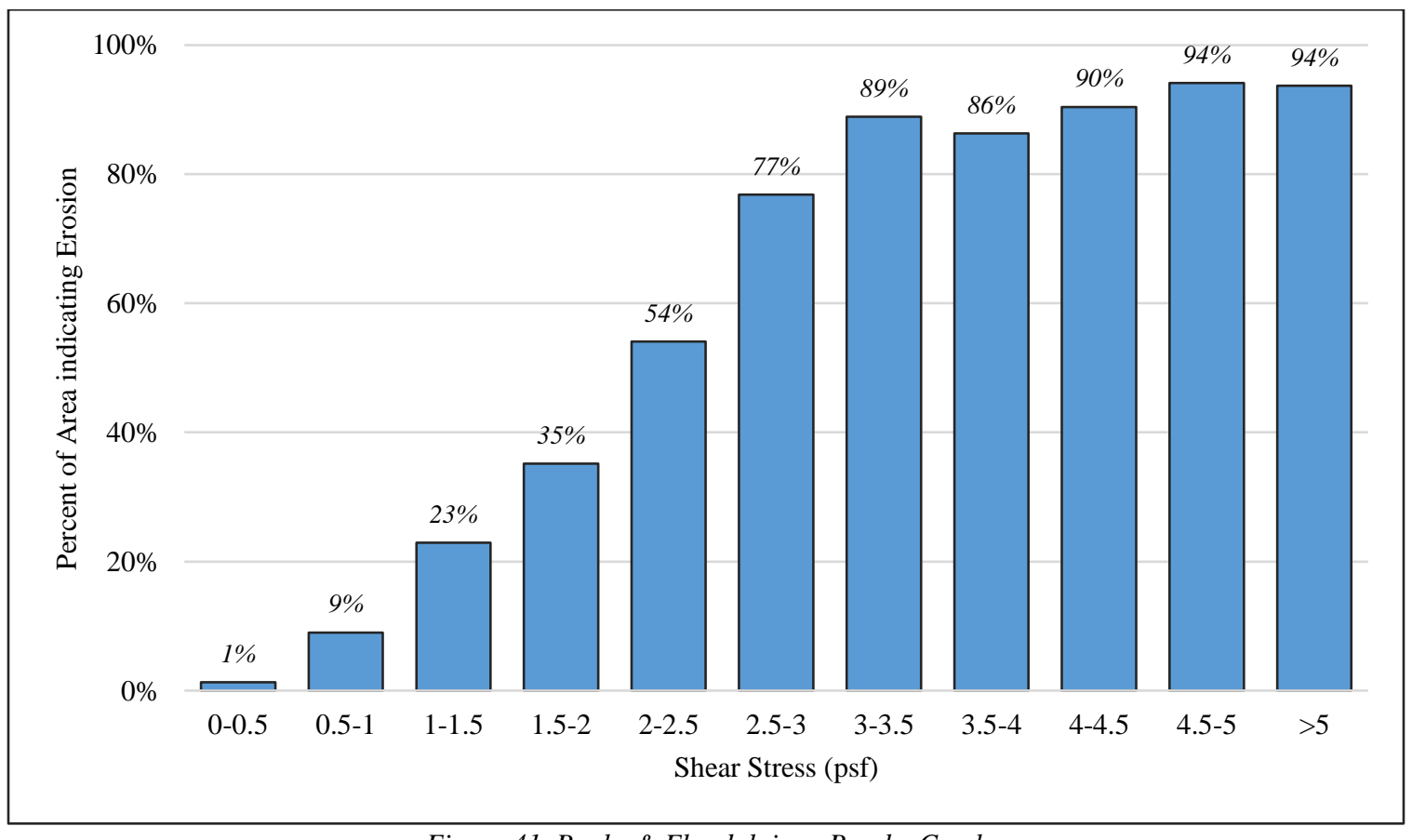

Figure 41. Banks \& Floodplains - Brushy Creek 


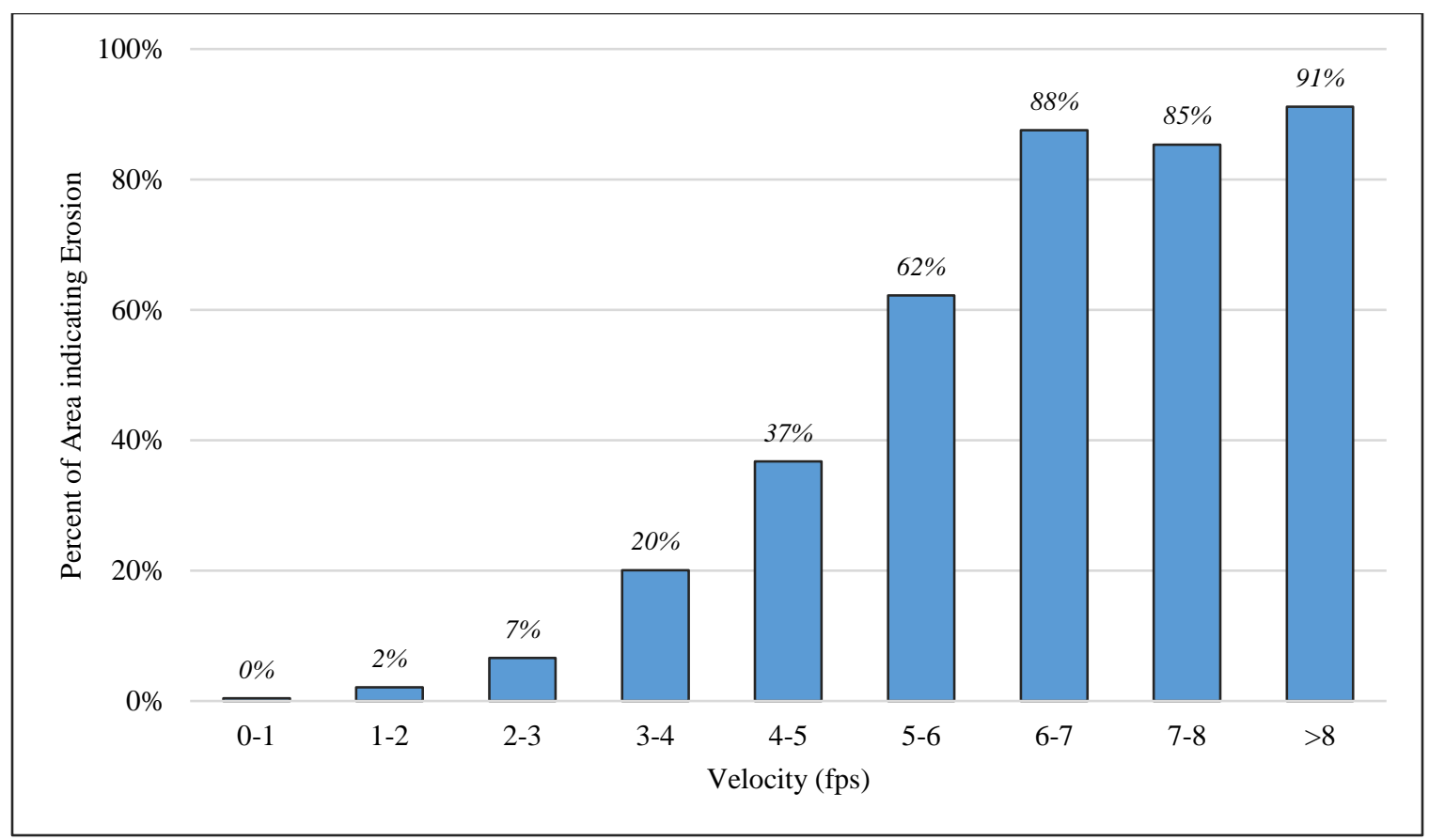

Figure 42. Banks \& Floodplains - Brushy Creek

Separate analysis of the floodplain for Slabcamp (Figure 43 and Figure 44) show that the percentage of area eroded for modeled shear stress and velocities of less than 3.5 psf (Figure 43) and 5 fps (Figure 44), respectively are relatively small while the percent area eroded is significantly higher for shear stresses greater than 4 psf (Figure 43) and velocity greater than 6 psf (Figure 44).

Separate analysis of the banks of Slabcam (Figure 45 and Figure 46) did not show the same clear transition from low percentage area of erosion to high percentage area of erosion. There is, however, a clear increase in percentage area eroded at stresses greater than 4 psf and velocities greater than $6 \mathrm{fps}$. 


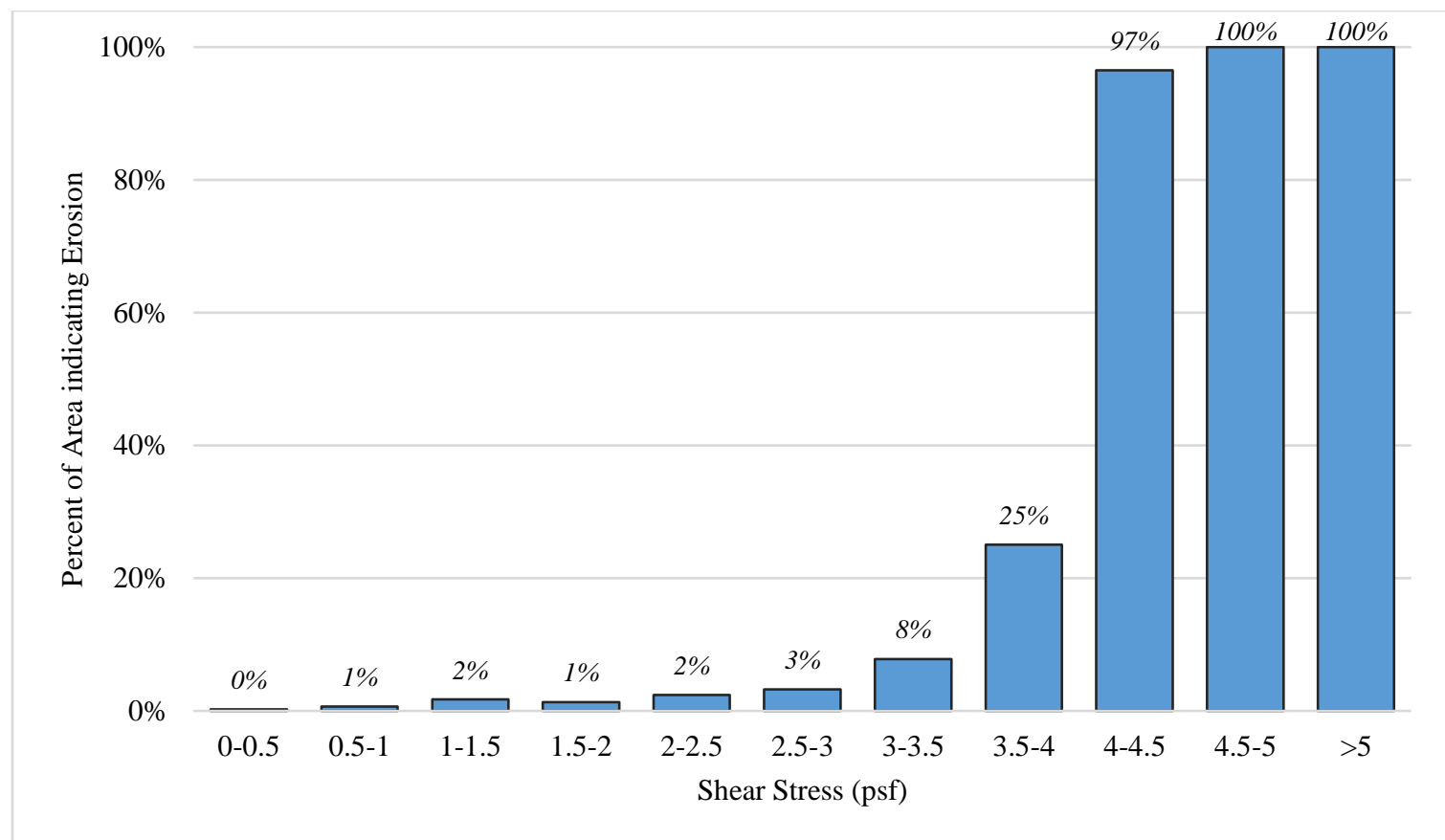

Figure 43. Floodplains - Slabcamp Creek

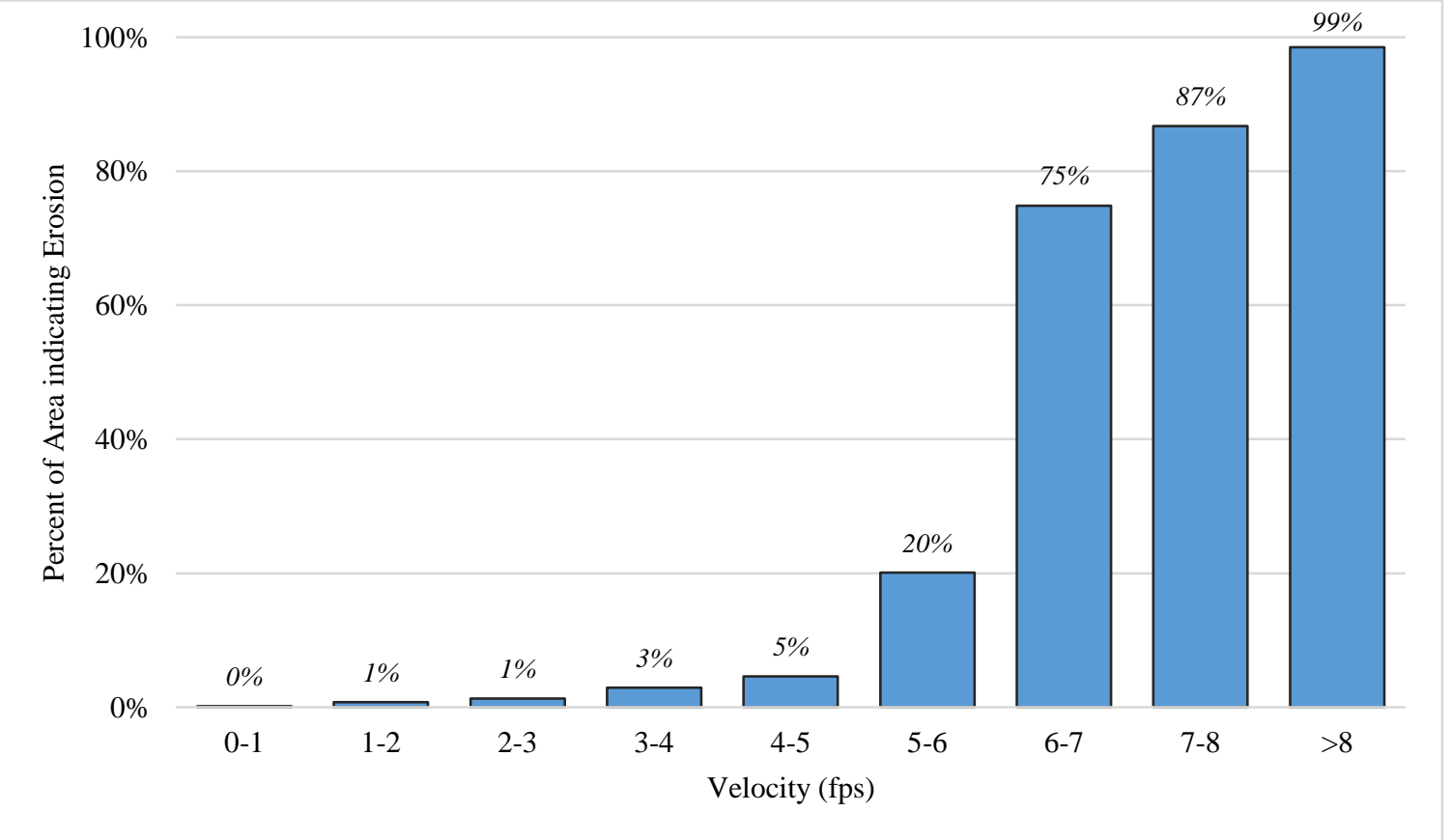

Figure 44. Floodplains - Slabcamp Creek 


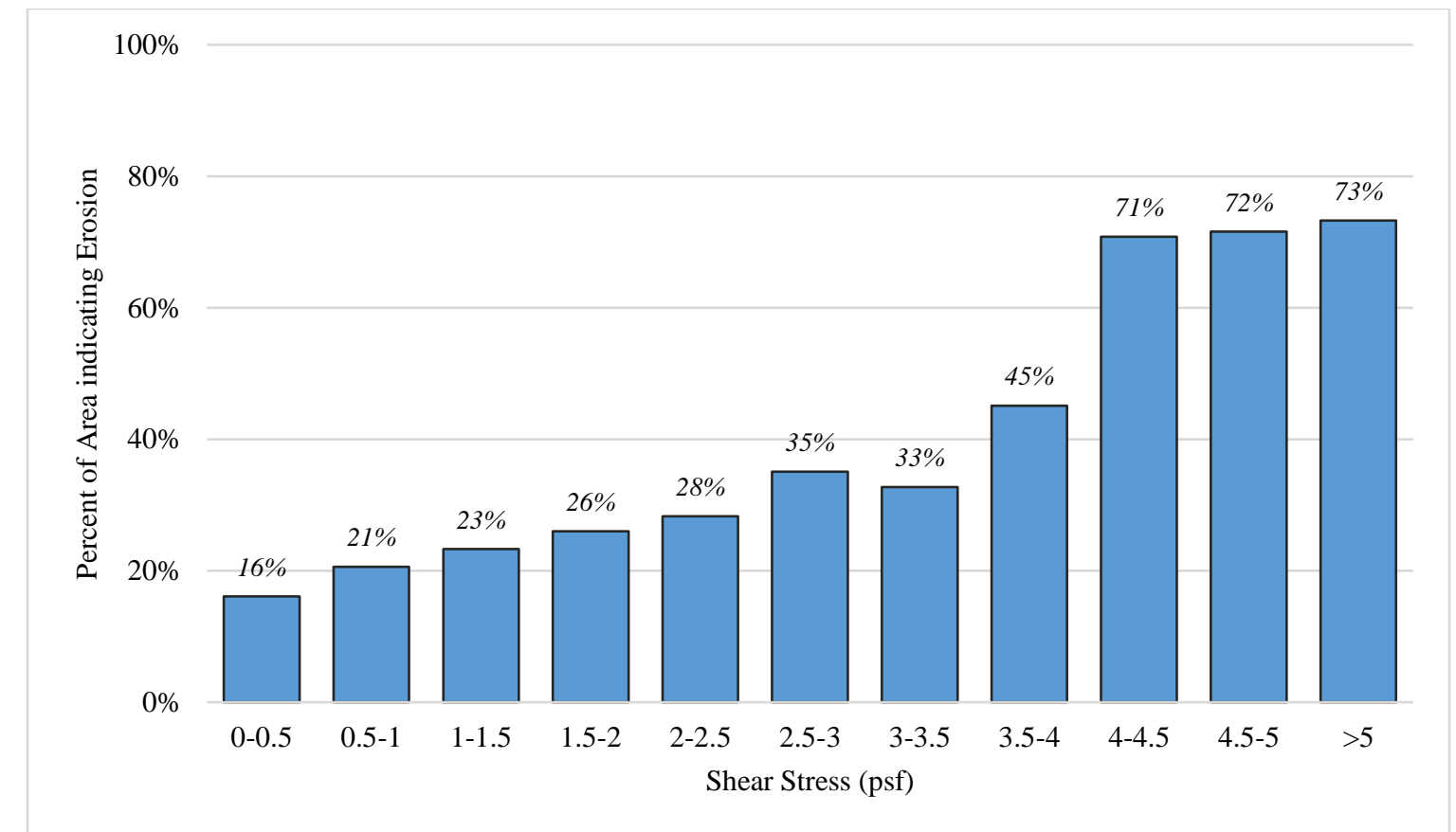

Figure 45. Banks - Slabcamp Creek

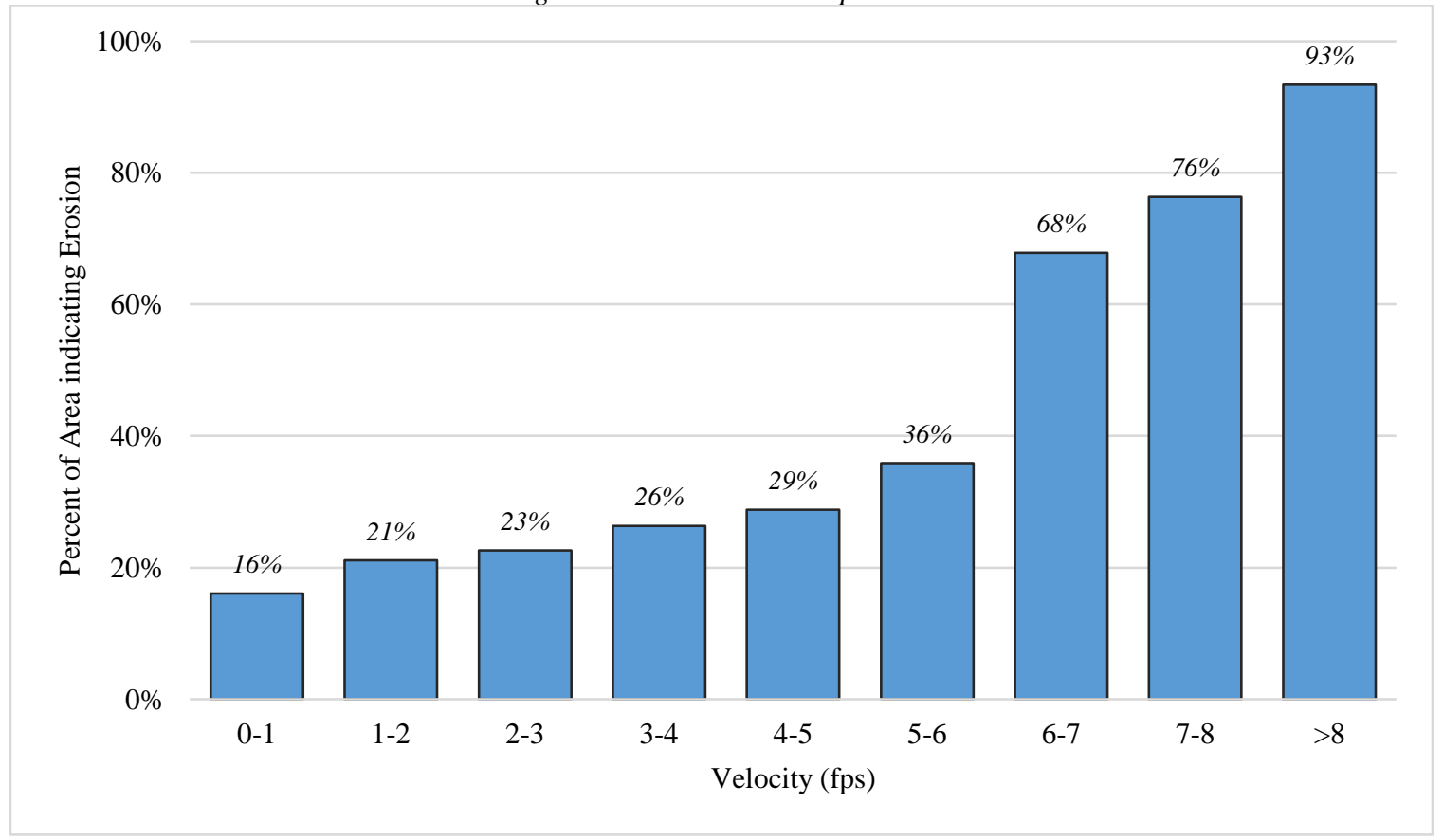

Figure 46. Banks - Slabcamp Creek

Separate analysis of the floodplain for Brushy (Figure 47 and Figure 48) show that the percentage of area eroded for modeled shear stress and velocities is gradual: shear stress between 0 psf and 3.5 psf (Figure 47) and velocity between 2 and 7 fps (Figure 48). In 
both the Slabcamb and Brushy analysis for the floodplain areas, shear stress over 4 psf and velocity over 6 fps showed high percentage area of erosion.

Separate analysis of the banks for Brushy (Figure 49 and Figure 50) show that the percentage of area eroded for modeled shear stress and velocities is gradual as well: shear stress between $0 \mathrm{psf}$ and $3.5 \mathrm{psf}$ (Figure 49) and velocity between 3 and $6 \mathrm{fps}$ (Figure 50). In both the Slabcamb and Brushy analysis for the bank areas, shear stress over 4 psf and velocity over 6 fps showed high percentage area of erosion.

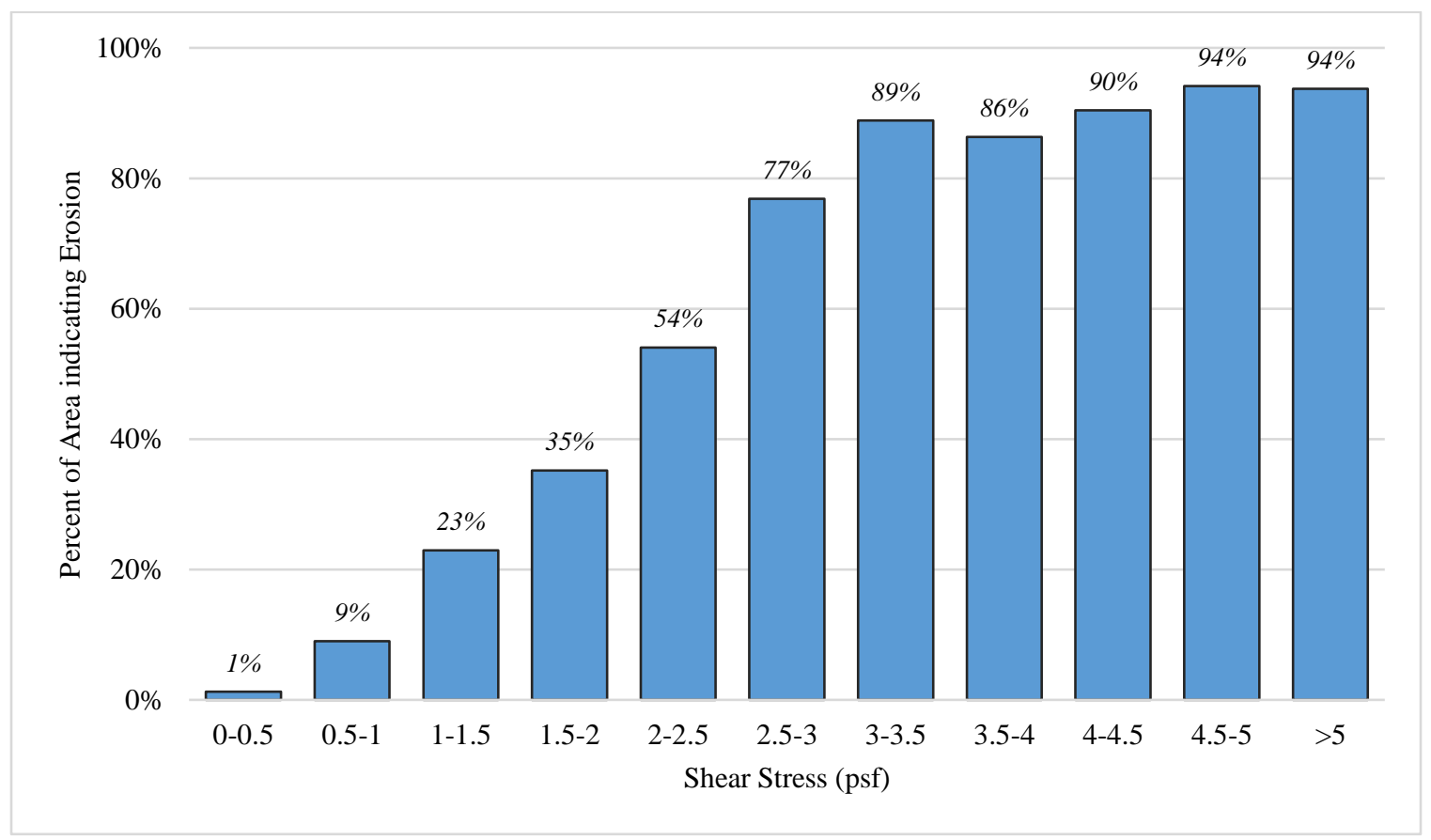

Figure 47. Floodplains - Brushy Creek 


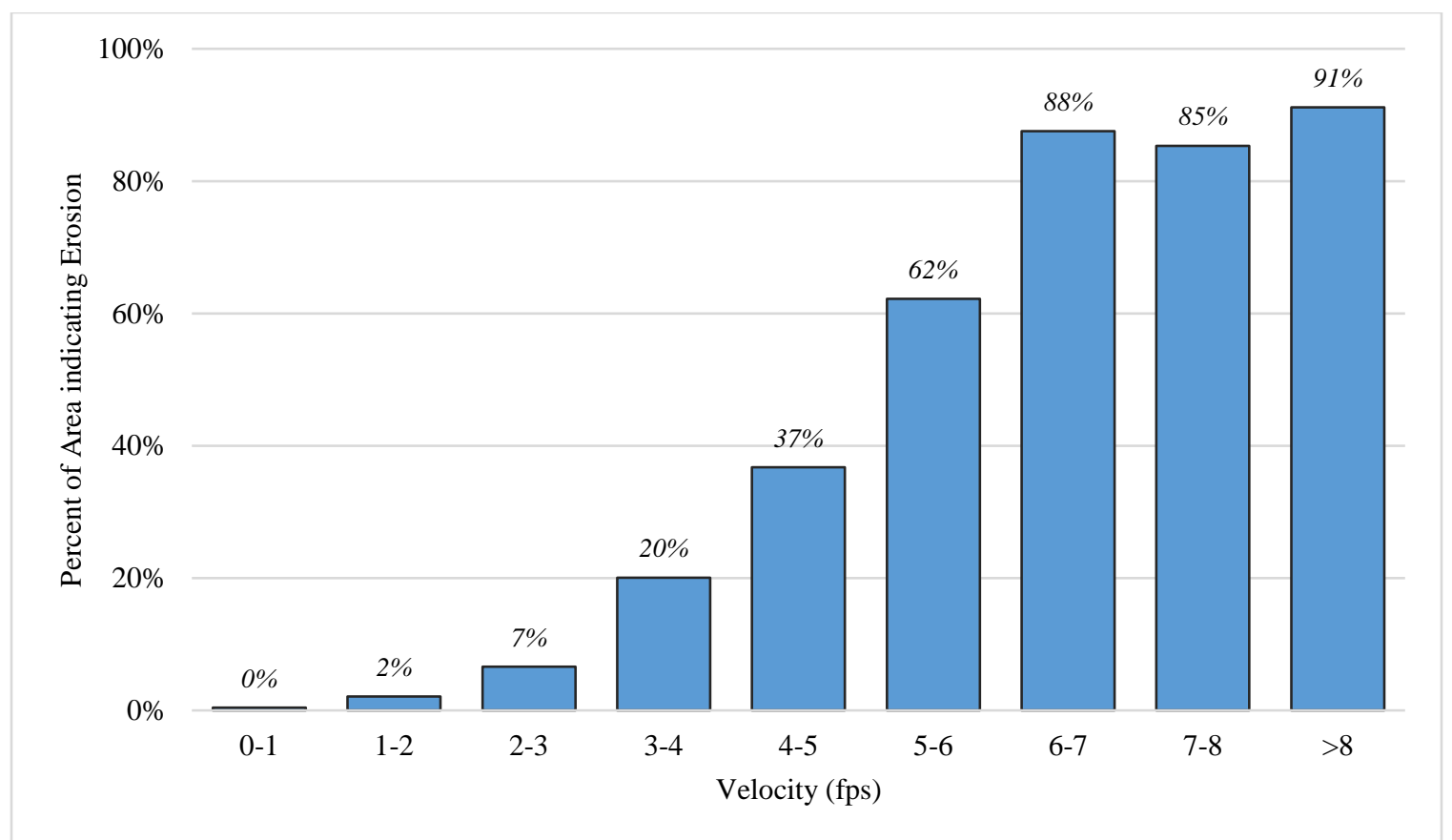

Figure 48. Floodplains - Brushy Creek

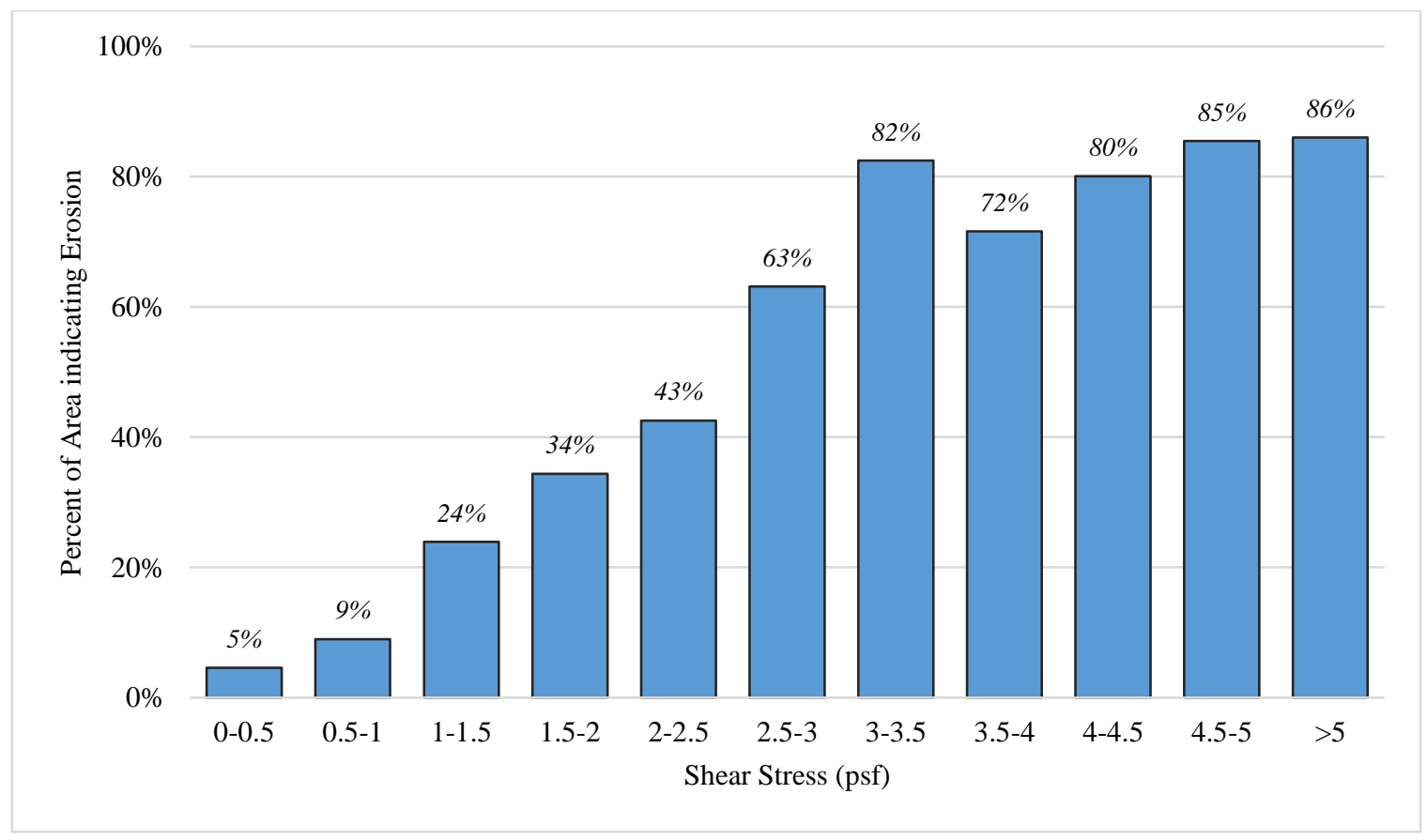

Figure 49. Banks - Brushy Creek 


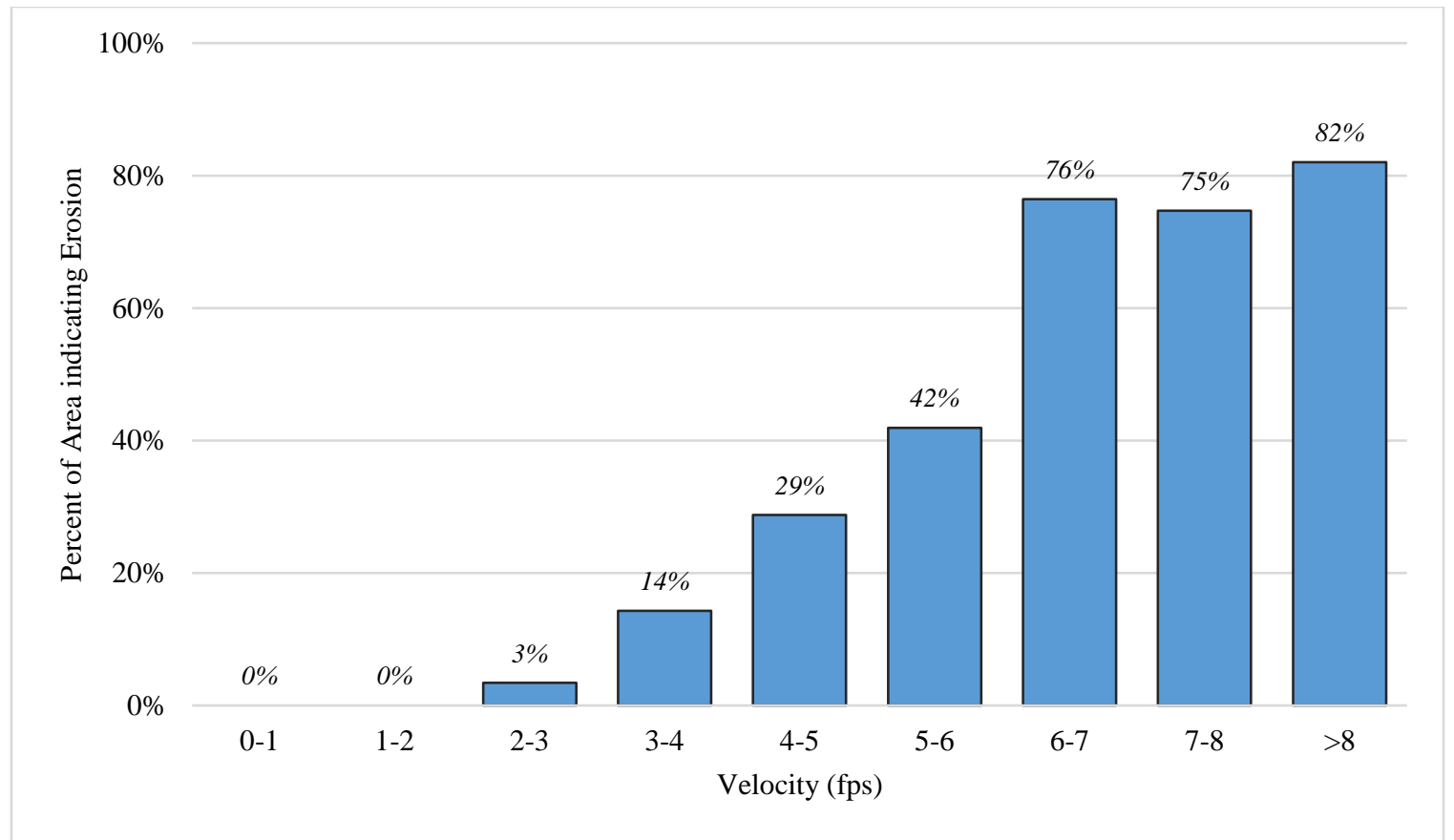

Figure 50. Banks - Brushy Creek 


\section{CHAPTER 5}

\section{DISCUSSION OF RESULTS}

\subsection{Model Sensitivity, Uncertainty and Error}

The sensitivity analysis of modeled shear stress and velocity with variation inflow floodplain (roughness held constant) at both sites provided useful information about the expected error in estimated shear and velocity with uncertainty in the estimated flow rates. An estimate of the error associated with flow uncertainty (Error! Reference source not $\mathrm{f}$ ound.) was developed using the maximum changes between the 50-year and 200-year values of cross section average stress and velocity and maximum changes in the peak values of stress and velocity for both floodplains and channels of both restoration sites. The floodplain values were more sensitive to variation in flow than the channel values. This is in part because flow in the channel did not change as much as flow in the floodplains with increases in total flow at both sites. The sensitivity analysis indicates that both average and peak values of shear stress and velocity of the channels are not highly sensitive to changes in flow in the range of the 50-year to 200-year flows (26-29\% change in flow) for restorations similar to Slabcamp and Brushy Creek. Floodplain stresses are considerably more sensitive to variation in flow than velocity magnitude. 


\begin{tabular}{|c|c|c|c|c|}
\multirow{2}{*}{ Table 46. Shear stress and velocity sensitivity and flow uncertainty error } \\
\cline { 2 - 5 } & \multicolumn{2}{|c|}{ Floodplain } & \multicolumn{2}{c|}{ Channel } \\
\cline { 2 - 5 } & $\begin{array}{c}\text { Max } \\
\text { Change }\end{array}$ & Error & $\begin{array}{c}\text { Max } \\
\text { Change }\end{array}$ & Error \\
\hline Ave Stress & $37.9 \%$ & $19.0 \%$ & $4.3 \%$ & $2.2 \%$ \\
\hline Peak Stress & $17.8 \%$ & $8.9 \%$ & $10.0 \%$ & $5.0 \%$ \\
\hline Ave Velocity & $21.7 \%$ & $10.8 \%$ & $7.0 \%$ & $3.5 \%$ \\
\hline Peak Velocity & $11.0 \%$ & $5.5 \%$ & $6.5 \%$ & $3.2 \%$ \\
\hline
\end{tabular}

The sensitivity analysis of modeled shear stress and velocity with variation in roughness (flow held constant) at both sites provided useful information about the expected error in estimated shear stress and velocity with uncertainty in the estimated floodplain roughness. An estimate of the error associated with uncertainty of the floodplain roughness was developed using the maximum changes between the floodplain roughness of 0.07 and 0.09 for values of cross section average stress and velocity and maximum changes in the peak values of stress and velocity for both floodplains and channels at both sites. As would be expected, the floodplain values of average shear stress and peak shear stress were more sensitive to variation in floodplain roughness than the channel values. However, the reduction in shear stress in the channels at both sites (Table 47) with increased roughness in the floodplain was not expected. Increases in floodplain roughness was expected to increase flow to the channel, potentially increasing velocity, energy dissipation, and shear stress. This is an interesting result because it suggested that roughening up the floodplain could lead to lower shear stresses in the channel. Reducing shear stress in channels is part of a goal to improve channel stability in many stream restorations. The reduction in channel stress with increased floodplain roughness should be examined more comprehensively in future studies. Both average values and peak values of floodplain shear stress were much more sensitive (about 3 to 4 times) to variation in floodplain roughness than floodplain average velocities and peak values. This indicates that average and peak 
values of velocity are much less affected by the selection of roughness values than average and peak values of shear stress.

\begin{tabular}{|c|c|c|c|c|}
\hline & \multicolumn{2}{|c|}{ Floodplain } & \multicolumn{2}{|c|}{ Channel } \\
\hline & $\begin{array}{c}\text { Max } \\
\text { Change }\end{array}$ & $\begin{array}{l}\text { Estimated } \\
\text { Error }\end{array}$ & $\begin{array}{c}\text { Max } \\
\text { Change }\end{array}$ & $\begin{array}{c}\text { Estimated } \\
\text { Error }\end{array}$ \\
\hline Ave Stress & $28.0 \%$ & $14.0 \%$ & $-16.4 \%$ & $8.2 \%$ \\
\hline Peak Stress & $33.4 \%$ & $16.7 \%$ & $-7.9 \%$ & $3.9 \%$ \\
\hline Ave Velocity & $-10.3 \%$ & $5.2 \%$ & $-6.5 \%$ & $3.2 \%$ \\
\hline Peak Velocity & $-7.2 \%$ & $3.6 \%$ & $-6.8 \%$ & $3.4 \%$ \\
\hline
\end{tabular}

5.2 Erosion Susceptibility of Floodplain \& Bank Surfaces

\section{Shear stress}

Interpretation of the percent floodplain and percent bank area eroded and its variation with shear stress (Figure 51) and velocity (Figure 52) as an indicator of probability of erosion can provide rough estimates of erosion susceptibility with modeled shear stress (Table 48) and velocity (Table 49).

More than $25 \%$ of the bank and floodplain areas at both sites for modeled stress greater than 3.75 psf indicating a very high susceptibility for both bank and floodplain erosion. The Slabcamp floodplain data show very low percentage of eroded area up to 2.75 psf, minor percent eroded area between 2.75 and $3.25 \mathrm{psf}$, and rapidly increasing percentage erosion beyond $3.25 \mathrm{psf}$. These percentage areas of erosion were used to develop erosion susceptibilities for floodplains similar to that of Slabcamp (Table 48).

The Slabcamp bank data indicates some ambiguity: 16\% percent area eroded at a very low stress of $0.25 \mathrm{psf}$. A threshold is indicated at approximately $3.25 \mathrm{psf}$ where the percent eroded area rises rapidly with increases in shear stress. This rapid rise is in the observed percent bank eroded is similar to that of the floodplain data for Slabcamp. The 
high percent eroded computed for very low shear stress is believed to be related to several factors that include changes in the streambanks that occurred soon after the as-built survey before vegetation was established and the relatively low total area of the banks. Small errors in 1) the bank survey, 2) transition from channel to bank roughness, 3) identified area of erosion areas, and 4) the percent areas misidentified as erosion are amplified by the small area of the very low banks (most less than 1 foot high) at Slabcamp. A more specific approach to analysis of the susceptibility of the small banks needs to be developed to provide a more reliable assessment of bank susceptibility. Although the Slabcamp bank data does not provide an indication of low erosion susceptibility, it does indicate that banks with stresses in excess of $3.25 \mathrm{psf}$ are highly susceptible to erosion.

The floodplain and bank data for Brushy show a gradual increase in percent area eroded with increasing in shear stress and lack the threshold behavior found in the Slabcamp data. The high percentage area eroded (24\%) at $1.25 \mathrm{psf}$ for both floodplain and banks may be a result of bank and floodplain erosion and channel migration prior to establishment of vegetation in addition to errors in modeled velocity associated with changes in topography caused by deposition, bar formation and channel migration that continued throughout the monitoring period. The Brushy data does indicate very high susceptibility at shear stress greater than 3 psf.

Fischenich (2001) suggests permissible boundary shear stress in the range of $1.2-$ $1.7 \mathrm{psf}$ for long native grasses based on a literature of erosion thresholds for vegetation [87]. These permissible stresses are significantly lower than would be inferred by the modeled stresses on the floodplain of Slabcamp. At Slabcamp, the floodplain surface vegetation was primarily emergent herbaceous wetland vegetation, different than long 
native grasses. In addition, permissible shear stress criteria from most studies are based on flow depth and spatially average estimates of energy dissipation rates approximated from water surface slope, bed slope or computed from cross-section averages. These shear stress estimates do not include the local roughness effects and therefore are unlikely to be accurate when compared to more direct measurement and/or estimates that include local roughness and energy dissipation rates.

\section{Velocity}

Where modeled velocities were greater than $5.5 \mathrm{fps}$, more than $20 \%$ of the bank and floodplain areas (at both sites and for both banks and floodplains) were identified as eroded indicating a very high susceptibility for bank and floodplain erosion. The Slabcamp floodplain data show very low percentage of eroded area up to $3.5 \mathrm{fps}$, minor percentage eroded area between 3.5 and 4.5 fps, and rapidly increasing percentage erosion beyond 4.5 fps.

Again, the Slabcamp bank data indicate some ambiguity - a 16\% percent area of erosion at a very low velocity of $0.5 \mathrm{fps}$. This is believed to be related to the same factors as discussed earlier: changes in the stream banks that occurred soon after the as-built survey before vegetation was established and the relatively low total area of the banks. Small errors in 1) the bank location, 2) velocity distribution, 3) identified area of erosion areas, and 4) areas misidentified as erosion are amplified by the small area of the banks (most less than 1 foot high) at Slabcamp. Again, more specific approach to analysis of the susceptibility of the small height banks needs to be developed to provide a more reliable assessment of bank susceptibility. Although the Slabcamp bank data does not provide an 
indication of low erosion susceptibility, it does indicate that bank areas with velocity in excess of 5.5 fps are highly susceptible to erosion.

The floodplain and bank data for Brushy show a gradual increase in eroded area with increasing in velocity from about $1.5 \mathrm{fps}$ to $6.5 \mathrm{fps}$; This may be, in part, a result of bank and floodplain erosion and channel migration prior to establishment of vegetation in addition to errors in modeled velocity associated with large changes in topography caused by deposition, bar formation and channel migration that continued throughout the monitoring period. Regardless, the Brushy data does clearly show very high susceptibility at velocities greater than about $4.5 \mathrm{fps}$.

Fischenich (2001) suggests permissible velocity in the range of $4-6$ fps for long native grasses based on a literature of erosion thresholds for long native grass [87]. The permissible velocity range approximately matches the transition from low susceptibility (less than $3.5 \mathrm{fps}$ ) to very high susceptibility (greater than $5.5 \mathrm{fps}$ ) for the Slabcamp Data (Table 49).

At Slabcamp, the floodplain surface was primarily emergent herbaceous wetland vegetation which is different than the long native grasses on which the criteria in Fischenich (2001) was based. Unlike the permissible shear stress estimates, velocities used in the development of the criteria were directly measured or are computed and not dependent on a local roughness estimate. 


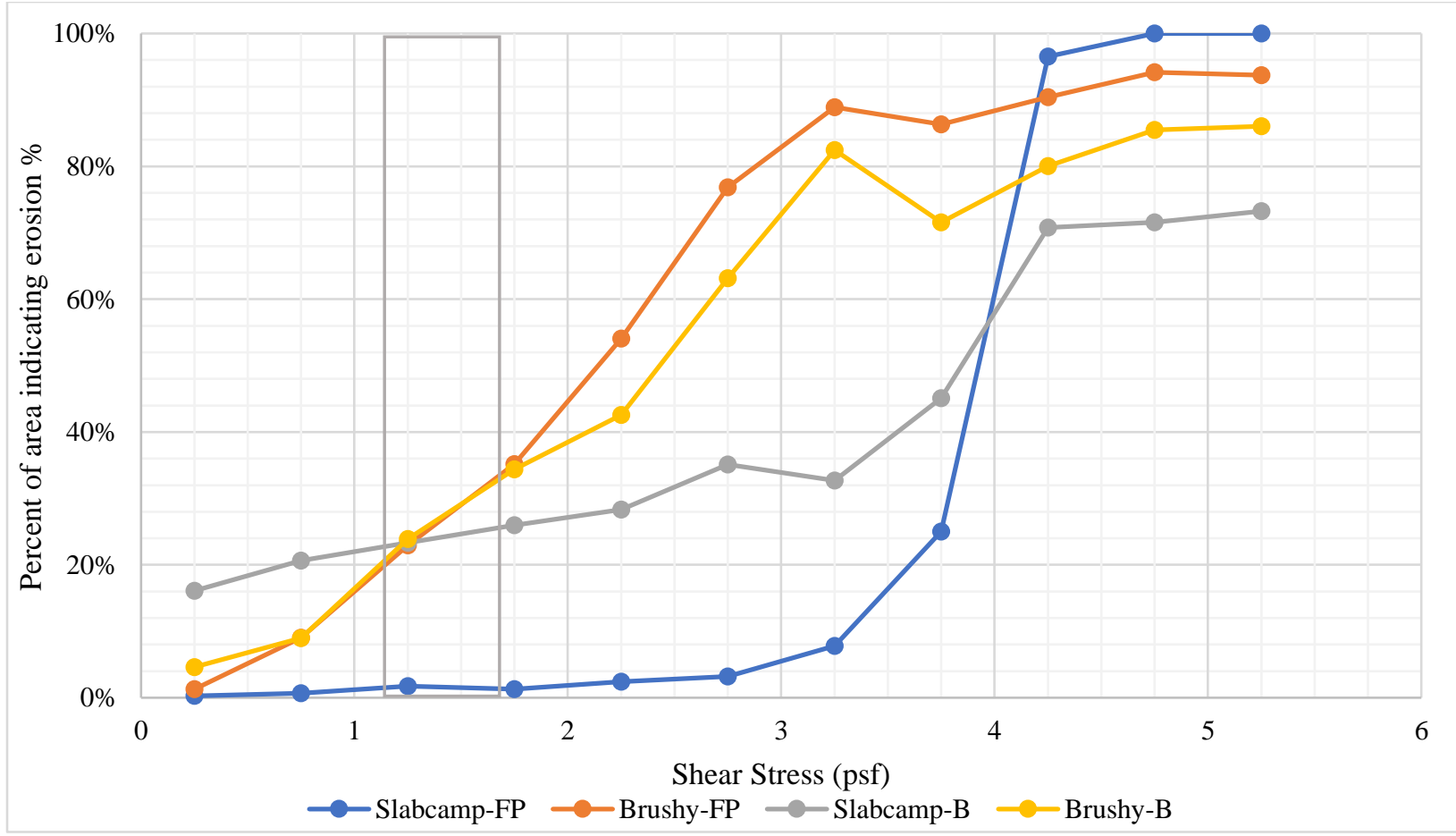

Figure 51. Percent Area of erosion variation with model shear stress for floodplains and bank. Box represents permissible stresses provided by Fischenich (2001).

Table 48. Floodplain surface susceptibility to modeled shear stress with Manning $n=0.07$ based on Slabcamp Creek modeling results.

\begin{tabular}{|c|c|c|}
\hline $\begin{array}{c}\text { Percent of area } \\
\text { indicating Erosion }(\%)\end{array}$ & $\begin{array}{c}\text { Erosion } \\
\text { Susceptibility }\end{array}$ & $\begin{array}{c}\text { Shear Stress } \\
(\mathrm{psf})\end{array}$ \\
\hline$<3$ & Low & $<2.75$ \\
\hline $3-8$ & Medium & $2.75-3.25$ \\
\hline $8-25$ & High & $3.25-3.75$ \\
\hline$>25$ & Very High & $>3.75$ \\
\hline
\end{tabular}




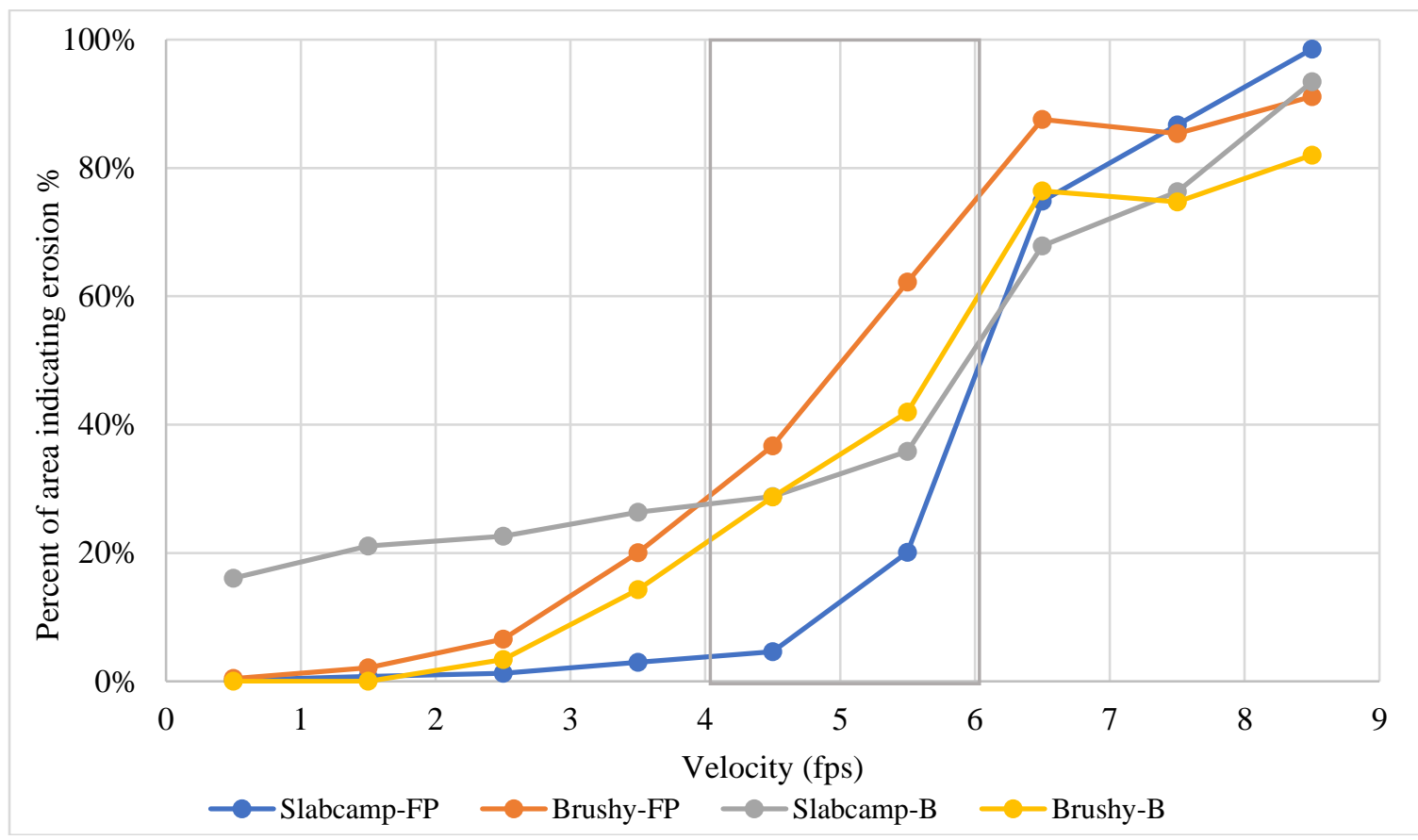

Figure 52. Percent Area of erosion variation with model velocity for floodplains and banks. Box represents permissible velocity range for native grasses provided by Fischenich (2001).

Table 49. Floodplain surface susceptibility to modeled velocity with Manning $n=0.07$ based on Slabcamp Creek modeling results

\begin{tabular}{|c|c|c|}
\hline $\begin{array}{c}\text { Percent of area } \\
\text { indicating erosion }(\%)\end{array}$ & $\begin{array}{c}\text { Erosion } \\
\text { susceptibility }\end{array}$ & Velocity (fps) \\
\hline$<3$ & Low & $<3.5$ \\
\hline $3-5$ & Moderate & $3.5-4.5$ \\
\hline $5-20$ & High & $4.5-5.5$ \\
\hline$>20$ & Very High & $>5.5$ \\
\hline
\end{tabular}




\section{CHAPTER 6}

\section{CONCLUSION}

Model shear stresses consistently have a step-like change in magnitude at the channel banks where roughness changes rapidly from the channel bed to the channel banks and on to the floodplain. Much of the change is caused by the discrete change in roughness coefficient that is selected by the modeler and is meant to be representative of a larger region of similar roughness characteristics. This very sharp shear stress transition from the channel to the banks and floodplain may not be representative of the actual shear stresses. Moreover, 2D model velocity magnitude is much less sensitive to local changes in roughness and therefore does not exhibit the rapid step-like variation of shear stress that was found near channel banks. For this reason, velocity may be a better parameter to evaluate erosion thresholds where large changes in roughness occur.

Model shear stress is sensitive to variation in roughness. This is an important consideration for 1) the selection of roughness coefficients, 2) erosion thresholds based on shear stress (the thresholds may not be independent of roughness coefficients), and 3) the evaluation of model stresses where roughness changes from low values such as the channel to high values such as a rough floodplain. It was interesting that channel shear stress may decrease with increases in channel roughness.

Application of a combination of field observation and 2D modeling was used to assess the risk of having erosion in stream restoration projects. The results of this study 
clearly show an increase in the percent area of erosion with increases in model shear stress and velocity magnitude on the stream banks and floodplains. On the site where herbaceous wetland vegetation was well established, a relatively narrow range of shear stress values was identified over which the erosion susceptibility increased rapidly from low to very high. A similar velocity range was identified. Comparison of threshold shear stress values found in the literature for herbaceous vegetation were significantly lower than were indicated by regions of low erosion susceptibility. Threshold values of velocity magnitude found in the literature for herbaceous vegetation were within the range of medium to very high susceptibility.

Modeling results can be used to identify areas of streambanks and floodplains vegetated with well-established herbaceous wetland vegetation that have either a very high susceptibility to erosion, transitional susceptibility, or that have a very low susceptibility. These conclusions are applicable to high sediment transport streams to identify areas that are susceptible to high stress prior to major changes in topography that may occur as a result of bar formation and deposition. 


\section{CHAPTER 7}

\section{RECOMMENDATION}

The literature review presented in Chapter 2 identified many areas of stream restoration design that would benefit from. If this study would have done again, there could be some added efforts to the methods. As an example, it could be tried to identify and apply more effective methods for recognizing erosion after vegetation has established. In addition, topographic survey after the vegetation has established could be conducted; so, the initial geometric changes can be separated from those that occurred prior to the establishment.

Further research also is needed that focuses on more detailed evaluation of the model in specific areas of erosion. This study provides erosion susceptibility for wellestablished herbaceous wetland vegetation on floodplain surfaces; however, similar work should be completed for streambanks and the floodplain for other types of vegetation and for habitat, grade control, and bank stabilization structures.

The relationship between computed shear stress, roughness coefficients and

threshold values for erosion should be examined further because of the large variation of shear stress with variation in roughness coefficient observed in t 2D model results. 


\section{REFERENCES}

1. Sala, O.E., et al., Global Biodiversity Scenarios for the Year 2100. 2000. 287(5459): p. 1770-1774.

2. $\quad$ Kauffman, J.B., et al., An Ecological Perspective of Riparian and Stream Restoration in the Western United States. Fisheries, 1997. 22(5): p. 12-24.

3. BROWN, A.G., Learning from the past: palaeohydrology and palaeoecology. 2002. 47(4): p. 817-829.

4. $\quad$ Bennett, S.J., et al., The Evolving Science of Stream Restoration, in Stream Restoration in Dynamic Fluvial Systems. 2013, American Geophysical Union. p. 1-8.

5. PALMER, M.A., et al., Standards for ecologically successful river restoration. 2005. 42(2): p. 208-217.

6. $\quad$ Bernhardt, E.S., et al., Synthesizing U.S. River Restoration Efforts. 2005. 308(5722): p. 636-637.

7. Dudgeon, D., et al., Freshwater biodiversity: importance, threats, status and conservation challenges. Biol Rev Camb Philos Soc, 2006. 81(2): p. 163-82.

8. Murdock, J.N., Stream Restoration, in Encyclopedia of Ecology, S.E. Jørgensen and B.D. Fath, Editors. 2008, Academic Press: Oxford. p. 3390-3397.

9. Kondolf, G.M., Five Elements for Effective Evaluation of Stream Restoration. 1995. 3(2): p. 133-136.

10. Frissell, C.A. and R.K. Nawa, Incidence and Causes of Physical Failure of Artificial Habitat Structures in Streams of Western Oregon and Washington. 1992. 12(1): p. 182-197.

11. Kondolf, G.M., M.W. Smeltzer, and S.F. Railsback, Design and Performance of a Channel Reconstruction Project in a Coastal California Gravel-Bed Stream. Environmental Management, 2001. 28(6): p. 761-776.

12. Harper, D., Watershed Restoration: Principles and Practices. Edited by J. E. Williams, C. A. Wood and M. P. Dombeck. Reviews in Fish Biology and Fisheries, 1999. 9(1): p. 122-123.

13. Johnson, P.A. and E.R. Brown, INCORPORATING UNCERTAINTY IN THE DESIGN OF STREAM CHMNEL MODIFICATIONS1. 2001. 37(5): p. 12251236.

14. Leopold, L.B., M.G. Wolman, and J.P. Miller, Fluvial processes in geomorphology. 1964, New York, NY: Dover Publications, Inc.

15. Miller, J. and R.C. Kochel, Assessment of Channel Dynamics, In-Stream Structures and Post-Project Channel Adjustments in North Carolina and Its Implications to Effective Stream Restoration. Environmental earth sciences, 2010. 59: p. 1681-1692.

16. Buchanan, B.P., et al., Monitoring and assessment of a river restoration project in central New York. 2012. 28(2): p. 216-233. 
17. Arthur C. Parola, J., et al., Storing Sediment in a Coastal Plain Valley Plug: Obion Creek Stream Restoration, in World Environmental and Water Resources Congress 2008. 2008. p. 1-10.

18. Diamond, J.M., Guns, germs, and steel : the fates of human societies. 2005: New York : Norton, [2005] @2005.

19. EPA, Environmental Impact and Benefits Assessment for Final Effluent Guidelines and Standards for the Construction and Development Category 2009, Office of Water (4303T) U.S. Environmental Protection Agency p. 375.

20. Hilderbrand, R.H., A. C. Watts, and A. M. Randle, The myths of restoration ecology. Ecology and Society, 2005. 10(1).

21. Department of the Army, C.o.E.a.E.P.A., Compensatory Mitigation for Losses of Aquatic Resources; Final Rule 2008.

22. BERNHARDT, E.S. and M.A. PALMER, Restoring streams in an urbanizing world. 2007. 52(4): p. 738-751.

23. PALMER, M.A., H.L. MENNINGER, and E. BERNHARDT, River restoration, habitat heterogeneity and biodiversity: a failure of theory or practice? 2010. 55(s1): p. 205-222.

24. Simon, A., et al., Critical Evaluation of How the Rosgen Classification and Associated "Natural Channel Design" Methods Fail to Integrate and Quantify Fluvial Processes and Channel Response1. 2007. 43(5): p. 1117-1131.

25. Shields, F.D., et al., Design for Stream Restoration. 2003. 129(8): p. 575-584.

26. Fischenich, C., Functional Objectives for Stream Restoration. 2006: p. 19.

27. Woolsey, S., et al., A Strategy to Assess River Restoration Success. Freshwater Biology, 2007. 52: p. 752-769.

28. Guilfoyle, M.P.F., Richard A., Guidelines for Establishing Monitoring Programs to Assess the Success of Riparian Restoration Efforts in Arid and Semi-Arid Landscapes 2006.

29. Paulsen, S.G., et al., Condition of stream ecosystems in the US: an overview of the first national assessment. 2008. 27(4): p. 812-821.

30. Roni, P., et al., A Review of Stream Restoration Techniques and a Hierarchical Strategy for Prioritizing Restoration in Pacific Northwest Watersheds. North American Journal of Fisheries Management, 2002. 22(1): p. 1-20.

31. Mumba, M. and J.R. Thompson, Hydrological and ecological impacts of dams on the Kafue Flats floodplain system, southern Zambia. Physics and Chemistry of the Earth, Parts A/B/C, 2005. 30(6): p. 442-447.

32. Eden, S. and S. Tunstall, Ecological Vs Social Restoration? How Urban River Restoration Challenges but Also Fails to Challenge the Science-Policy Nexus in the United Kingdom. Environment and Planning C: Government and Policy, 2006. 24: p. 661-680.

33. Smith, S.M. and K.L. Prestegaard, Hydraulic performance of a morphology-based stream channel design. 2005. 41(11).

34. Wilcock, P., Sediment Transport in the Restoration of Gravel-Bed Rivers. ASCE Conference Proceedings, 2004. 138.

35. Doll, B.A., et al., Stream restoration: a natural channel design handbook. 2003. 
36. Clewell, A. and J. Aronson, Ecological Restoration: Principles, Values, and Structure of an Emerging Profession. Bibliovault OAI Repository, the University of Chicago Press, 2007.

37. Miller, J.R. and R. Craig Kochel, Assessment of channel dynamics, in-stream structures and post-project channel adjustments in North Carolina and its implications to effective stream restoration. Environmental Earth Sciences, 2010. 59(8): p. 1681-1692.

38. Kondolf, G.M. and P.R. Wilcock, The Flushing Flow Problem: Defining and Evaluating Objectives. 1996. 32(8): p. 2589-2599.

39. Bash, J.S. and C.M. Ryan, Stream Restoration and Enhancement Projects: Is Anyone Monitoring? Environmental Management, 2002. 29(6): p. 877-885.

40. Wohl, E., et al., River restoration. 2005. 41(10).

41. Lave, R., M. Doyle, and M. Robertson, Privatizing stream restoration in the US. 2010. 40(5): p. 677-703.

42. $\quad$ Rosgen, D., Applied River Morphology. 1996.

43. Langendoen, E. and A. Simon, Modeling the Evolution of Incised Streams. II: Streambank Erosion. Journal of Hydraulic Engineering-asce - J HYDRAUL ENG-ASCE, 2008. 134.

44. Prato, T. and D. Hey, ECONOMIC ANALYSIS OF WETLAND RESTORATION ALONG THE ILLINOIS RIVER1. 2006. 42(1): p. 125-131.

45. Simon, A., et al., Reply to Discussion by Dave Rosgen 2 .: "Critical Evaluation of How the Rosgen Classification and Associated 'Natural Channel Design' Methods Fail to Integrate and Quantify Fluvial Processes and Channel Responses". Journal of The American Water Resources Association - J AM WATER RESOUR ASSOC, 2008. 44: p. 793-802.

46. Downs, P.W., et al., Restoring Ecological Integrity in Highly Regulated Rivers: The Role of Baseline Data and Analytical References. Environmental Management, 2011. 48(4): p. 847-864.

47. Ernst, A.G., D.R. Warren, and B.P. Baldigo, Natural-Channel-Design Restorations That Changed Geomorphology Have Little Effect on Macroinvertebrate Communities in Headwater Streams. 2012. 20(4): p. 532-540.

48. Violin, C.R., et al., Effects of urbanization and urban stream restoration on the physical and biological structure of stream ecosystems. 2011. 21(6): p. 19321949.

49. Hassett, B., et al., Restoring watersheds project by project: trends in Chesapeake Bay tributary restoration. 2005. 3(5): p. 259-267.

50. Potyondy, C.C.H.C.L.R.J.P., Stream channel reference sites: An illustrated guide to field technique. Gen. Tech. Rep. RM-245. Fort Collins, CO: U.S. Department of Agriculture, Forest Service, Rocky Mountain Forest and Range Experiment Station. 61 p., 1994.

51. Davis, N.M., et al., An Assessment of Water Quality, Physical Habitat, and Biological Integrity of an Urban Stream in Wichita, Kansas, Prior to Restoration Improvements (Phase I). Archives of Environmental Contamination and Toxicology, 2003. 44(3): p. 0351-0359.

52. Rao, P.G., Climatic changes and trends over a major river basin in India CLIMATE RESEARCH, 1993. 2: p. 215-223. 
53. Kumar, J., et al., Study and Overview about Process Failure Mode and Effects Analysis on Automotive Timing Chain. International Journal of Automotive and Mechanical Engineering, 2019. 2: p. 17-21.

54. Poff, N.L., et al., Sustainable water management under future uncertainty with eco-engineering decision scaling. Nature Climate Change, 2016. 6(1): p. 25-34.

55. Schwartz, J.S., et al., Restoring riffle-pool structure in an incised, straightened urban stream channel using an ecohydraulic modeling approach. Ecological Engineering, 2015. 78: p. 112-126.

56. Lai, Z., et al., Impact of multichannel river network on the plume dynamics in the Pearl River estuary. 2015. 120(8): p. 5766-5789.

57. Neary, V.S., B. Gunawan, and D.C. Sale, Turbulent inflow characteristics for hydrokinetic energy conversion in rivers. Renewable and Sustainable Energy Reviews, 2013. 26: p. 437-445.

58. Biron, P., R. Carver, and D. Carré, Sediment Transport and Flow Dynamics in a Fish-Habitat Restoration Project: Field and Numerical Experiments. AGU Fall Meeting Abstracts, 2009: p. 06.

59. van Vuuren, D.P., et al., A proposal for a new scenario framework to support research and assessment in different climate research communities. Global Environmental Change, 2012. 22(1): p. 21-35.

60. Clilverd, H.M., et al., Coupled Hydrological/Hydraulic Modelling of River Restoration Impacts and Floodplain Hydrodynamics. 2016. 32(9): p. 1927-1948.

61. Leyer, I., E. Mosner, and B. Lehmann, Managing floodplain-forest restoration in European river landscapes combining ecological and flood-protection issues. Ecological Applications, 2012. 22(1): p. 240-249.

62. Hughes, F.M.R., et al., The importance of different scale processes for the restoration of floodplain woodlands. 2001. 17(4-5): p. 325-345.

63. Riis, T., et al., Seed germination from deposited sediments during high winter flow in riparian areas. Ecological Engineering, 2014. 66: p. 103-110.

64. $\mathrm{Xu}, \mathrm{W}$., et al., Antibiotics in riverine runoff of the Pearl River Delta and Pearl River Estuary, China: Concentrations, mass loading and ecological risks. Environmental Pollution, 2013. 182: p. 402-407.

65. Lai, Y.G., et al., Modeling of multilayer cohesive bank erosion with a coupled bank stability and mobile-bed model. Geomorphology, 2015. 243: p. 116-129.

66. Crowder, D.W. and P. Diplas, Using Two-Dimensional Hydrodynamic Models at Scales of Ecological Importance. Journal of Hydrology, 2000. 230: p. 172-191.

67. Pasternack, G.B., et al., Error propagation for velocity and shear stress prediction using 2D models for environmental management. Journal of Hydrology, 2006. 328(1): p. 227-241.

68. Pasternack, G.B., M.K. Bounrisavong, and K.K. Parikh, Backwater control on riffle-pool hydraulics, fish habitat quality, and sediment transport regime in gravel-bed rivers. Journal of Hydrology, 2008. 357(1): p. 125-139.

69. Poulsen, J.B., et al., Linking floodplain hydraulics and sedimentation patterns along a restored river channel: River Odense, Denmark. Ecological Engineering, 2014. 66: p. 120-128. 
70. Schwartz, J.S., Use of a 2D Hydrodynamic Model for Stream Restoration Design of High-flow Habitat in Low-gradient Midwest Streams, in Protection and Restoration of Urban and Rural Streams. 2004. p. 242-251.

71. E. Bollaert, J.D., L. Maumary, S. André \& P. Hohl, Restoration of the Broye delta into the Lake of Morat (Salavaux, Switzerland). 2014.

72. Wheaton, J.M., G.B. Pasternack, and J.E. Merz, Spawning habitat rehabilitation II. Using hypothesis development and testing in design, Mokelumne river, California, U.S.A. International Journal of River Basin Management, 2004. 2(1): p. 21-37.

73. Wen, L., et al., Assessing stream restoration works in the southern Macquarie Marshes using hydrodynamic modelling. 2013.

74. Brown, R.A., G.B. Pasternack, and T. Lin, The Topographic Design of River Channels for Form-Process Linkages. Environmental Management, 2016. 57(4): p. 929-942.

75. Branco, P., et al., Boulders as building blocks: improving habitat and river connectivity for stream fish. 2013. 6(4): p. 627-634.

76. Alfredsen, K., et al., Application of habitat modelling in river rehabilitation and artificial habitat design. 2004. 14: p. 105-117.

77. Pasternack, G.B., C.L. Wang, and J.E. Merz, Application of a $2 D$ hydrodynamic model to design of reach-scale spawning gravel replenishment on the Mokelumne River, California. 2004. 20(2): p. 205-225.

78. Stelling, G.S., On the Construction of Computational Methods for Shallow Water Flow Problems. 1984: Goverment Pub. Office.

79. WBM, B., Newcastle Flash Flood: 8 June 2007 (the Pasha Bulker Storm), Flood Data

Compendium. 2008: Newcastle City Council, BMT WBM, Broadmeadow.

80. Gregory B. Pasternack, C.H., L Near-census 2D model comparison between SRH$2 D$ and TUFLOWGPU for use in gravel/cobble rivers. 2017, University of California, Davis, CA: Yuba County Water Agency.

81. Bates, P.D., Remote sensing and flood inundation modelling. 2004. 18(13): p. 2593-2597.

82. Merwade, V., D. Maidment, and B. Hodges, Geospatial Representation of River Channels. Journal of Hydrologic Engineering - J HYDROL ENG, 2005. 10.

83. Merwade, V., et al., Uncertainty in Flood Inundation Mapping: Current Issues and Future Directions. Journal of Hydrologic Engineering - J HYDROL ENG, 2008. 13.

84. Tate, E.C., et al., Creating a Terrain Model for Floodplain Mapping. 2002. 7(2): p. 100-108.

85. Martin, G.A.H.a.G.R., Estimating the Magnitude of Peak Flows for Streams in Kentucky for Selected Recurrence Intervals. 2003, U.S. Geological Survey: U.S. Department of the Interior.

86. Chow, V.T., Open-Channel Hydraulics. 1959, New York: McGraw-Hill.

87. Fischenich, C., Stability Thresholds for Stream Restoration Materials. 2001: p. 11. 


\section{CURRICULUM VITAE}

\section{Fereshteh Noorbakhsh}

Department of Civil Engineering

J.B. Speed School of Engineering

University of Louisville

Louisville, KY 40292

\section{Education}

- $\quad$ Fall 2015-Spring 2020: Ph.D. in Civil Engineering

J.B. Speed School of Engineering University of Louisville (UofL), Louisville, Kentucky

- $\quad$ Fall 2010 - Spring 2013: M.Sc. in Civil Engineering (River Eng.) Power and Water University of Technology ( $\underline{\text { PWUT)}}$, Tehran, Iran

- Fall 2005- Summer 2009: B.S. in Civil Engineering (Geotechnical Eng.) University of Tabriz (UofT), Tabriz, Iran

\section{Honors and Awards}

- UofL-National Science Foundation I-Corps Research Award, Spring 2017

- University Fellowship- J.B. Speed School of Engineering, Fall 2015 - Fall 2017

- Full Graduate Assistantship - J.B. Speed School of Engineering, Fall 2015 Present

\section{Publications}

\section{Journal Papers:}

- F.Noorbakhsh, M.R.M. Tabatabai, M.H. Kharazifard, "Experimental Investigation of Scour Hole Length and Reynolds number variations under 
Different Bank Slopes in Rivers". Modares Civil Engineering Journal (M.C.E.J), Vol. 14, No. 1, Spring 2014

\section{Conference Papers}

- World Environmental and Water Resources Congress 2018, "F. Noorbakhsh, A. C. Parola", "Numerical Investigation of the Effect of River Modeling Parameters on Bed Shear Stress"

- 9th International Congress on River Engineering, January 22, 2013, Iran, "F.Noorbakhsh, M.R.M. Tabatabai, M.H.Kharazifard" "Experimental investigation of effective factor causes internal erosion in river bank,

- 12nd National Congress on Hydraulic, October 29, 2013, Iran "M.R.M. Tabatabai, F.Noorbakhsh, H.Salamat, A.Masoodi" "Investigate the relationship between scour depth and Reynolds number of porous media in vertical and sloping sides of the river" 